\title{
OCORRÊNCIA, PRODUÇÃO E PRESERVAÇÃO DE MICÉLIO SECO DE Batkoa sp. e Furia sp., PATÓGENOS DAS CIGARRINHAS DAS PASTAGENS
}

\author{
LUÍS GARRIGÓS LEITE
}

Tese apresentada à Escola Superior de Agricultura "Luiz de Queiroz", Universidade de São Paulo, para obtenção do título de Doutor em Ciências, Área de Concentração: Entomologia.

\section{PIRACICABA}

Estado de São Paulo - Brasil

Janeiro - 2002 


\title{
OCORRÊNCIA, PRODUÇÃO E PRESERVAÇÃO DE MICÉLIO SECO DE Batkoa sp. e Furia sp., PATÓGENOS DAS CIGARRINHAS DAS PASTAGENS
}

\section{LUÍS GARRIGÓS LEITE}

Engenheiro Agrônomo

\section{Orientador: Prof. Dr. SÉRGIO BATISTA ALVES}

\begin{abstract}
Tese apresentada à Escola Superior de Agricultura "Luiz de Queiroz", Universidade de São Paulo, para obtenção do título de Doutor em Ciências. Área de concentração: Entomologia
\end{abstract}

PIRACICABA

Estado de São Paulo - Brasil

Janeiro - 2002 
Dados Internacionais de Catalogação na Publicação (CIP)

DIVISÃO DE BIBLIOTECA E DOCUMENTAÇÃO - ESALQ/USP

\section{Leite, Luís Garrigós}

Ocorrência, produção e preservação de micélio seco de Batkoa sp. e Furia sp., patógenos das cigarrinhas das pastagens / Luís Garrigós Leite. - -

Piracicaba, 2002.

133 p. : il.

Tese (doutorado) - Escola Superior de Agricultura Luiz de Queiroz, 2002.

Bibliografia.

1. Cigarrinhas 2. Fungos entomopatogênicos 3. Pastagens I. Título

CDD 632.752

\section{"Permitida a cópia total ou parcial deste documento, desde que citada a fonte - O autor"}




\section{À minha esposa Otília OFEREÇO E DEDICO este trabalho.}




\section{AGRADECIMENTOS}

Ao Prof. Sérgio Batista Alves e Prof. Donald W. Roberts, pela orientação e coorientação, respectivamente, além do incentivo e grande amizade.

Aos Professores dos cursos de Pós-graduação em Entomologia da ESALQ e Utah State University, pelos ensinamentos e colaborações.

A Fundação Coordenação de Aperfeiçoamento de Pessoal de Nível Superior - CAPES, pela bolsa de estudos "sandwish" para realização do Doutorado na ESALQ/USP, com estágio na Utah State University, USA.

Ao Departamento de Entomologia da ESALQ e Departamento de Biologia da Utah State University pela acolhida e por ter colocado a disposição suas instalações, equipamentos e recursos.

Aos pesquisadores do Instituto Biológico/Laboratório de Controle Biológico, Dr. Antonio Batista Filho, Laerte Antonio Machado, Valmir Antonio Costa e José Eduardo Marcondes de Almeida, pela amizade e colaborações.

Aos amigos do curso de Pós-graduação em Entomologia, especialmente ao Marcel R. Tanzini, Marcos A. Tamai, Rogério Biagginoni Lopes, Marcos Barros de Medeiros, Daniella Macedo, Luciana Rossi e Ricardo A. Polanczyk.

Aos amigos do Depto. de Biologia da Utah State University, especialmente ao Gilberto L. Braga, Willian McManus, Tyler Gundersen e Rhett Grove. 
Aos funcionários do Depto. de Entomologia da ESALQ, especialmente a Solange Aparecida Vieira, e funcionários do Instituto Biológico, especialmente a Maria Estela Paulo de Camargo e Édson Mancuci.

E a todos que contribuíram na realização desse trabalho. 


\section{SUMÁRIO}

\begin{tabular}{|c|c|}
\hline \multicolumn{2}{|l|}{ 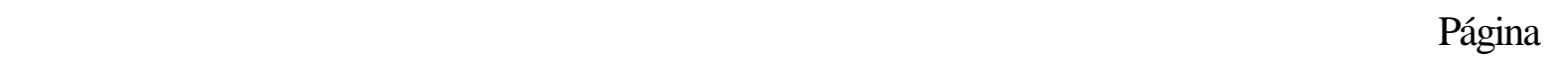 } \\
\hline LISTA DE FIGURAS & ix \\
\hline LISTA DE TABELAS & xiii \\
\hline 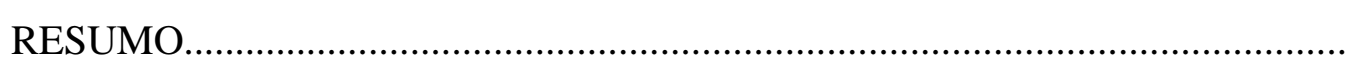 & xiv \\
\hline SUMMARY... & xvi \\
\hline 1 INTRODUÇÃO....... & \\
\hline REVISÃO DE LITERATURA... & \\
\hline 1 Cigarrinhas das pastagens........ & 4 \\
\hline 2.1.1 Hospedeiros......... & 4 \\
\hline 2.1.2 Bioecologia.... & \\
\hline 2.1.3 Condições climáticas favoráveis.. & \\
\hline 2.1.4 Inimigos naturais..... & \\
\hline 2.2 Fungos Entomophthorales....... & \\
\hline 2.1 Evolução taxonômica.. & \\
\hline 2.2.2 Ocorrência e especificidade... & 15 \\
\hline 2.2.3 Ciclo biológico e potencial epizoótico.... & 16 \\
\hline 2.2.4 Fatores limitantes.... & 20 \\
\hline 2.2.5 Produção............. & 25 \\
\hline 2.2.6 Formulação...... & 28 \\
\hline .2.7 Utilização de Entomophthorales. & \\
\hline 2.8 Seletivid & \\
\hline
\end{tabular}

3 OCORRÊNCIA NATURAL DE ENTOMOPHTHORALES EM POPULAÇÕES DAS CIGARRINHAS DAS PASTAGENS................................. 33

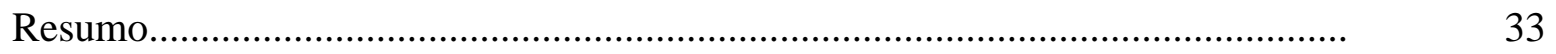




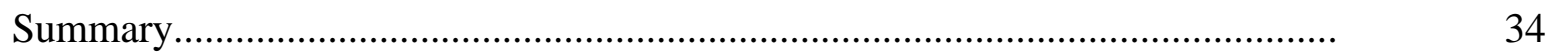

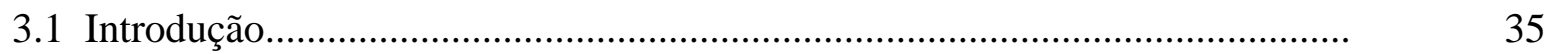

3.2 Material e Métodos.......................................................................................

3.3 Resultados e Discussão...................................................................................

3.4 Conclusões............................................................................................

4 EFEITO DE SAIS, VITAMINAS AÇÚCARES E FONTES DE NITROGÊNIO NA PRODUÇÃO DE ENTOMOPHTHORALES..........................

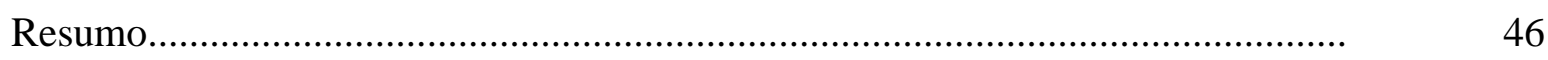

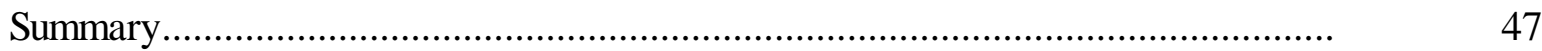

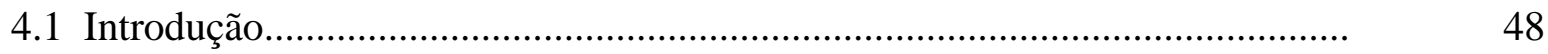

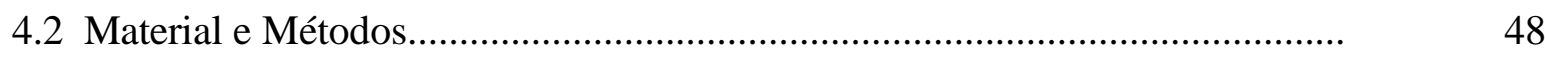

4.3 Resultados e Discussão................................................................................

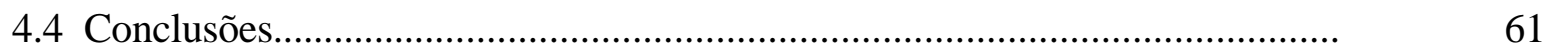

5 EFEITO DE FONTES DE NITROGÊNIO NA PRODUÇÃO DE

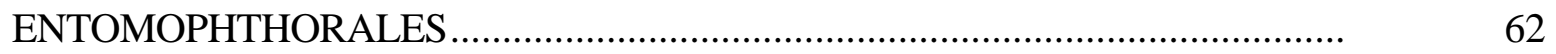

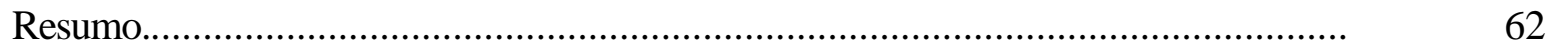

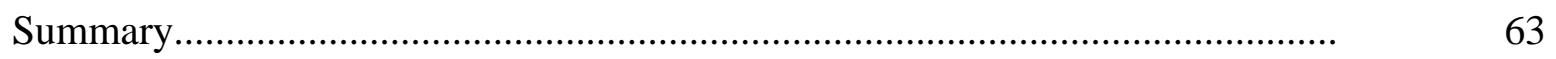

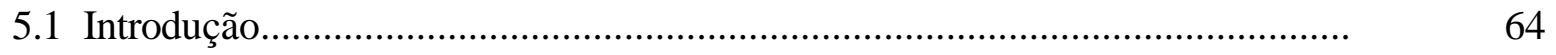

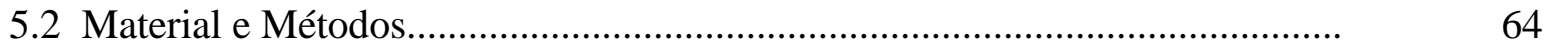

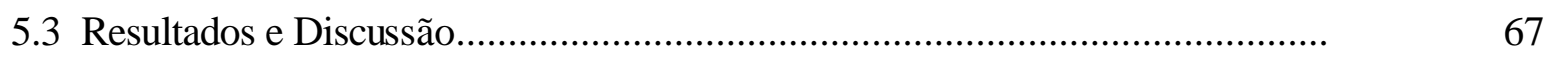

5.4 Conclusões............................................................................................

6 EFEITO DE DIFERENTES SAIS NA PRODUÇÃO DE

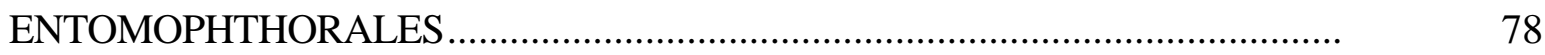

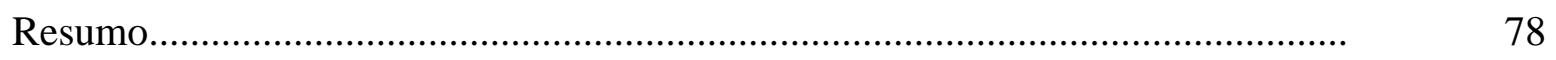

Summary

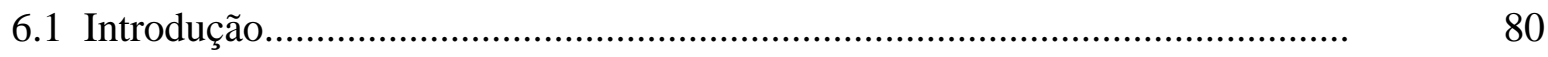

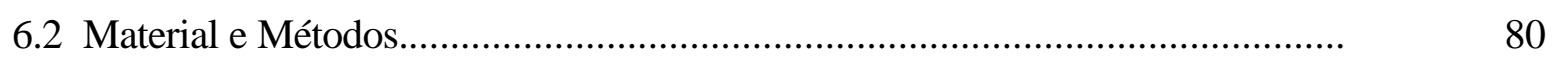

6.3 Resultados e Discussão...................................................................................

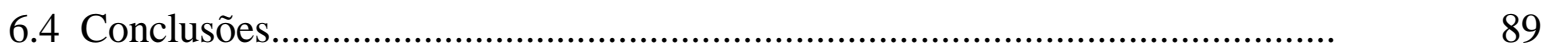

7 PRESERVAÇÃO DE MICÉLIO DE Batkoa sp. e Furia sp. (ENTOMOPHTHORALES) EM COMBINAÇÕES COM DESSECANTES E

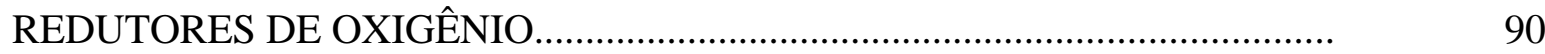




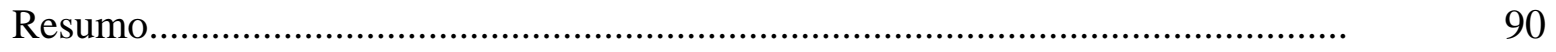

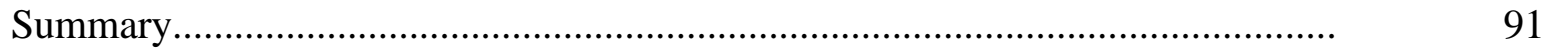

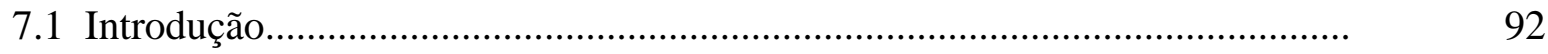

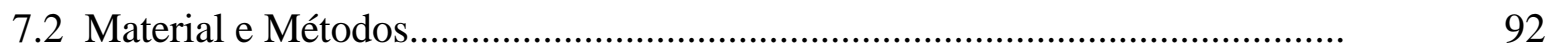

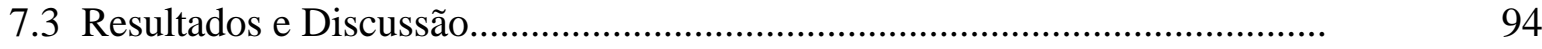

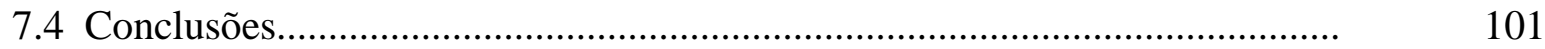

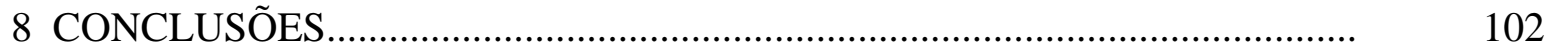

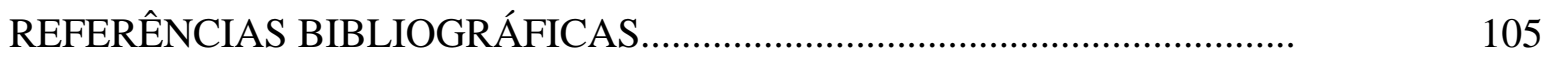

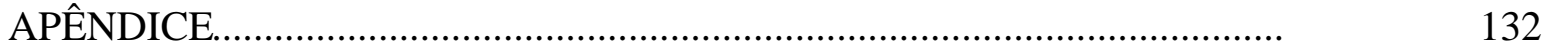




\section{LISTA DE FIGURAS}

Página

1 Mahanarva fimbriolata com Batkoa sp. (A), Deois schach com Furia sp. (B) e Tetranychus urticae com Neozygites floridana (C). Corpos hifais de Batkoa sp. (D), Furia sp. (E) e N. floridana (F) produzidos em meio líquido

2 Mahanarva fimbriolata (A) com Batkoa sp. Conidiogênese (B), esporos de resistência $(C)$ e conídios secundários (D e E) do fungo

3 Dois schach (A) com Furia sp. Conidiogênese (B) e conídios secundários (C e D) do fungo.

4 Incidência de Batkoa sp. na população de Mahanarva fimbriolata em pastagem de napier, correlacionada com os parâmetros meteorológicos.. Pindamonhangaba, SP, 1999

5 Incidência de Furia sp. na população de Deois schach em pastagem de Brachiaria decumbens, correlacionada com os parâmetros meteorológicos. Pindamonhangaba, SP, 1999.

6 Produção de biomassa dos fungos Batkoa sp. e Furia sp. em meios líquidos. $\mathrm{BA}=$ meio básico; $\mathrm{SA}=$ meio básico + sais; $\mathrm{VI}=$ meio básico + vitaminas; $\mathrm{AA}=$ meio básico + aminoácidos; $\mathrm{MC}=$ meio básico + os três componentes juntos; GS = meio Grace's suplementado. Tratamentos com a mesma letra não diferem entre si pelo teste de Tukey, ao nível de $5 \%$ de probabilidade. Barras $=$ desvio padrão 
7 Produção de Neozygites floridana em meios líquidos. BA = meio básico; $\mathrm{SA}=$ meio básico + sais; $\mathrm{VI}=$ meio básico + vitaminas; $\mathrm{AA}=$ meio básico + aminoácidos; $\mathrm{MC}=$ meio básico + os três componentes juntos; GS = meio Grace's suplementado. Barras = desvio padrão..........................

8 Produção de biomassa dos fungos Batkoa sp. e Furia sp. em meios líquidos. $\mathrm{DE}=$ glucose $(2,66 \%) ; \mathrm{SU}=$ sucrose $(2,66 \%) ; \mathrm{GL}=$ sucrose $(2,66 \%)+$ glucose $(0,1 \%) ; \mathrm{FR}=$ sucrose $(2,66 \%)+$ frutose $(0,1 \%) ; \mathrm{MA}=$ sucrose $(2,66 \%)+$ maltose $(0,1 \%) ;$ IN $=$ sucrose $(2,66 \%)+$ inositol $(0,1 \%) ; \mathrm{GS}=$ Grace's suplementado. Tratamentos com a mesma letra não diferem entre si pelo teste de Tukey, ao nível de 5\% de probabilidade. Barras $=$ desvio padrão

9 Produção de Neozygites floridana em meios líquidos. $\mathrm{DE}=$ glucose $(2,66 \%) ; \mathrm{SU}=$ sucrose $(2,66 \%) ; \mathrm{GL}=$ sucrose $(2,66 \%)+$ glucose $(0,1 \%) ;$ $\mathrm{FR}=$ sucrose $(2,66 \%)+$ frutose $(0,1 \%) ; \mathrm{MA}=$ sucrose $(2,66 \%)+$ maltose $(0,1 \%) ; \quad \mathrm{IN}=\operatorname{sucrose}(2,66 \%)+$ inositol $(0,1 \%) ; \mathrm{GS}=$ Grace's suplementado. Barras = desvio padrão.

10 Produção de Batkoa sp., Furia sp. e Neozygites floridana em meios de cultura líquidos com diferentes fontes de nitrogênio. GS = meio Grace's suplementado; LY = lactalbumina hidrolisada + yeastolate; $\mathrm{L}=$ lactalbumina; Y = yeastolate; YE = extrato de levedura; $\mathrm{GE}=$ gema de ovo; $\mathrm{LD}=$ leite desnatado; $\mathrm{SO}=$ soja $; \mathrm{PH}=$ proteína hidrolisada de soja; $\mathrm{EC}=$ extrato de carne $; \mathrm{XM}=$ xarope de milho $\mathrm{CH}=$ ácido de caseína hidrolisada; $\mathrm{PE}=$ peptona; $\mathrm{SL}=$ soro de leite. Tratamentos com a mesma letra não diferem entre si pelo teste de Tukey $(\alpha=0,05)$. Barras $=$ desvio padrão.

11 Produção de Batkoa sp. e Furia sp. em meios líquidos a base de diferentes combinações dos componentes leite desnatado (LD), extrato de levedura (YE), peptona (PE) e extrato de carne (EC). $\mathrm{MC}=$ meio completo; LY = lactalbumina hidrolisada + yeastolate; GS = Grace's suplementado. Tratamentos com a mesma letra não diferem entre si pelo teste de Tukey, ao nível de 5\% de probabilidade. Barras = desvio padrão.. 
12 Crescimento de Neozygites floridana em meios líquidos a base de diferentes combinações dos componentes leite desnatado (LD), extrato de levedura (YE), peptona (PE) e extrato de carne (EC). $\mathrm{MC}=$ meio completo; LY = lactalbumina hidrolisada + yeastolate; GS = Grace's suplementado. Tratamentos (linhas cheias) com picos de crescimento na primeira (A e B), segunda (C e D) e terceira semana (E e F). Barras $=$ desvio padrão

13 Produção de Batkoa sp. e Furia sp. em meios líquidos contendo concentrações totais de $1,2,3$ e $4 \%$ de extrato de levedura para o primeiro patógeno, e da mistura em iguais proporções de extrato de levedura, extrato de carne e peptona, para o segundo. GS = Grace's suplementado. Tratamentos com a mesma letra não diferem entre si pelo teste de Tukey, ao nível de $5 \%$ de probabilidade. Barras = desvio padrão.

14 Produção de Batkoa sp. e Furia sp. em meios líquidos contendo concentrações totais de 0,$25 ; 0,5 ; 0,75 ; 1$ e $2 \%$ de extrato de levedura para o primeiro patógeno, e da mistura em iguais proporções de extrato de levedura, extrato de carne e peptona para o segundo. GS = Grace's suplementado. Tratamentos com a mesma letra não diferem entre si pelo teste de Tukey, ao nível de 5\% de probabilidade. Barras = desvio padrão.

15 Produção de Neozygites floridana em meios líquidos contendo concentrações totais de 1, 2, 3 e 4\% da mistura em iguais proporções de extrato de carne, leite desnatado e peptona. GS = Grace's suplementado. Barras $=$ desvio padrão.

16 Produção de Batkoa sp. e Furia sp. em meios líquidos contendo $\mathrm{CaCl}_{2} \cdot 2 \mathrm{H}_{2} \mathrm{O}, \quad \mathrm{KCl}, \quad \mathrm{MgCl}_{2} \cdot 6 \mathrm{H}_{2} \mathrm{O}, \quad \mathrm{NaH}_{2} \mathrm{PO}_{4} \cdot \mathrm{H}_{2} \mathrm{O}, \quad \mathrm{MgSO}_{4} \cdot 7 \mathrm{H}_{2} \mathrm{O}$ e $\mathrm{NaHCO}_{3} . \mathrm{MB}=$ meio básico (sem sais). $\mathrm{SA}=$ meio contendo a mistura de todos os sais. GS = meio Grace's suplementado. Tratamentos com a mesma letra não diferem entre si pelo teste de Tukey, ao nível de 5\% de probabilidade. Barras = desvio padrão. 
17 Crescimento de Neozygites floridana em meios líquidos contendo $\mathrm{CaCl}_{2} \cdot 2 \mathrm{H}_{2} \mathrm{O}, \quad \mathrm{KCl}, \quad \mathrm{MgCl}_{2} \cdot 6 \mathrm{H}_{2} \mathrm{O}, \quad \mathrm{NaH}_{2} \mathrm{PO}_{4} \cdot \mathrm{H}_{2} \mathrm{O}, \quad \mathrm{MgSO}_{4} \cdot 7 \mathrm{H}_{2} \mathrm{O}$ e $\mathrm{NaHCO}_{3}$. Meios contendo $\mathrm{Mg}$ e K (A) e sem esses elementos (B). $\mathrm{MB}=$ meio básico (sem sais). $\mathrm{SA}=$ meio contendo a mistura de todos os sais. GS = meio Grace's suplementado. Barras = desvio padrão........................

18 Corpos hifais de Neozygites floridana produzidos em meio líquido contendo $\mathrm{MgSO}_{4}$ como único sal..........................................................

19 Viabilidade e crescimento de Batkoa sp. em meio sólido, após diferentes períodos de armazenamento do fungo na forma micélio seco, a $23^{\circ} \mathrm{C} \mathrm{e}$ $3^{\circ} \mathrm{C}$, embalado em diferentes combinações envolvendo vácuo (V), glicerol (G), sílica (S), Ageless (A) e testemunha (T). * Colônias originadas de grânulos de micélio seco após 6 dias de

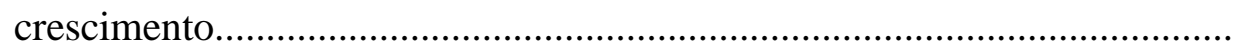

20 Viabilidade e crescimento de Furia sp. em meio sólido, após diferentes períodos de armazenamento do fungo na forma micélio seco, a $23^{\circ} \mathrm{C}$ e $3^{\circ} \mathrm{C}$, embalado em diferentes combinações envolvendo vácuo (V), glicerol (G), sílica (S), Ageless (A) e testemunha (T). * Colônias originadas de grânulos de micélio seco após 6 dias de crescimento 


\section{LISTA DE TABELAS}

Página

1 Estimativas dos parâmetros de regressão múltipla e coeficientes de correlação de Pearson (r) entre o desenvolvimento da doença (nível de infecção) de Batkoa sp., e a população de seu hospedeiro, Mahanarva fimbriolata, e os dados climáticos..................................................................

2 Estimativas dos parâmetros de regressão múltipla e coeficientes de correlação de Pearson (r) entre o desenvolvimento da doença (nível de infecção) de Furia sp. e a população de seu hospedeiro, Deois schach, e os dados climáticos.

3 Pressão osmótica (mOsm) de meios líquidos contendo 6 diferentes sais, para três diferentes fungos. $\mathrm{MB}=$ meio básico (sem sais). $\mathrm{SA}=$ meio contendo a mistura de todos os sais. Gr = Grace's suplementado com lactalbumina hidrolizada mais yeastolate

$4 \quad$ Viabilidade e crescimento Batkoa sp. em meio sólido, após 90 dias de armazenamento do fungo na forma de micélio seco, a $3^{\circ} \mathrm{C}$ e $23^{\circ} \mathrm{C}$, embalado em diferentes combinações envolvendo vácuo (V), glicerol $(\mathrm{G})$, sílica (S), Ageless (A) e testemunha (T). * Colonia originada de grânulos de micelio seco após 6 dias de crescimento

5 Viabilidade e crescimento Furia sp. em meio sólido, após 90 dias de armazenamento do fungo na forma de micélio seco, a $3^{\circ} \mathrm{C}$ e $23^{\circ} \mathrm{C}$, embalado em diferentes combinações envolvendo vácuo (V), glicerol (G), sílica (S), Ageless (A) e testemunha (T). * Colonia originada de grânulos de micelio seco após 6 dias de crescimento.............................................. 


\title{
OCORRÊNCIA, PRODUÇÃO E PRESERVAÇÃO DE MICÉLIO SECO DE Batkoa sp. e Furia sp., PATÓGENOS DAS CIGARRINHAS DAS PASTAGENS
}

\author{
Autor: LUÍS GARRIGÓS LEITE \\ Orientador: Prof. SÉRGIO BATISTA ALVES
}

\section{RESUMO}

Os fungos Batkoa sp. e Furia sp. (Entomophthorales), embora ocasionalmente ocorrendo de forma epizoótica em populações das cigarrinhas-das-pastagens e cana-deaçúcar, nunca foram avaliados quanto ao nível de incidência e potencial de controle biológico. Esse estudo teve por objetivo avaliar a ocorrência natural, produção "in vitro" e preservação de micélio seco desses fungos. Nos trabalhos de produção incluiu-se como padrão o fungo Neozygites floridana, representante de outra família de Entomophthorales. O estudo sobre a ocorrência natural foi realizado na região de Pindamonhangaba, SP, no período de 22 de janeiro a 9 de fevereiro de 1998 com o objetivo de avaliar a incidência de Batkoa sp. na população de Mahanarva fimbriolata em pastagem de capim napier e de Furia sp. sobre Deois schach em pastagem de Brachiaria sp. O estudo sobre produção foi realizado em condições de laboratório com o objetivo de desenvolver meios líquidos para a produção de micélio ou corpos hifais de Batkoa sp., Furia sp. e N. floridana, tendo como base o meio líquido para cultura de tecido de inseto Grace's suplementado, o qual permite bom crescimento do último patógeno. Finalmente, estudou-se o efeito da combinação de dois dessecantes (sílica e glicerol) com dois redutores de oxigênio (vácuo e Ageless® ZPT200) na preservação de micélio seco de Batkoa sp. e Furia sp. sob temperaturas de $3^{\circ} \mathrm{C}$ e $23^{\circ} \mathrm{C}$. Concluiu-se que: Batkoa sp. e Furia sp. causam doença na população de $M$. 
fimbriolata e D. schach, respectivamente; Furia sp. possui maior potencial epizoótico que Batkoa sp.; Batkoa sp., Furia sp. e N. floridana se assemelham quanto ao crescimento em meios adicionados de sais, vitaminas e aminoácido, e em meio completo; A adição de sais ao meio básico proporciona um aumento significativo na produção das três espécies de fungos, e maior do que a adição de vitaminas e aminoácidos; A mistura dos sais $\mathrm{CaCl}_{2} .2 \mathrm{H}_{2} \mathrm{O}(0,06 \%), \mathrm{KCl}(0,28 \%), \mathrm{MgCl}_{2} .6 \mathrm{H}_{2} \mathrm{O}(0,16 \%), \mathrm{MgSO}_{4} .7 \mathrm{H}_{2} \mathrm{O}(0,2 \%), \mathrm{NaHCO}_{3}$ $(0,03 \%)$ e $\mathrm{NaH}_{2} \mathrm{PO}_{4} \cdot \mathrm{H}_{2} \mathrm{O}(0,1 \%)$ proporciona maior produção dos fungos do que os sais avaliados isoladamente na concentração de $0,83 \%$; $\mathrm{O}$ sulfato de magnésio $\left(\mathrm{MgSO}_{4}\right)$ pode ser utilizado como único sal, na concentração de 0,83\%, visando a produção de Batkoa sp., Furia sp. e N. floridana; Esses fungos se assemelham quanto ao crescimento em meios contendo diferentes fontes de carbono, mas se diferenciam em meios com diferentes fontes de nitrogênio; $\mathrm{O}$ meio contendo 2,66\% de glucose proporciona uma produção das três espécies de fungos significativamente maior do que o meio com 2,66\% de sacarose; A adição de $0,1 \%$ de monossacarídeos no meio com $2,66 \%$ de sacarose não aumenta significativamente a produção dos fungos; $\mathrm{O}$ extrato de levedura proporciona maior produção de Batkoa sp.; A concentração de $0,5 \%$ de extrato de levedura é a mais adequada para a produção vegetativa de Batkoa sp.; A combinação de extrato de levedura + extrato de carne + leite desnatado proporciona a maior produção de Furia sp.; A combinação de extrato de levedura + leite desnatado proporciona o segundo maior rendimento de Furia sp., sendo mais adequada para a produção do fungo devido ao menor custo; A concentração de $1 \%$ da mistura dessas fontes de nitrogênio é adequada para a produção vegetativa de Furia sp.; A combinação de extrato de levedura + peptona + leite desnatado proporciona a maior produção de N. floridana; A concentração de $3 \%$ da mistura dessas fontes de nitrogênio é adequada para a produção vegetativa de $N$. floridana; A combinação de sílica + Ageless® prolonga a sobrevivência desses dois fungos formulados como micélio seco até 90 dias, armazenados a $3^{\circ} \mathrm{C}$ e $23^{\circ} \mathrm{C}$; O uso de vácuo como redutor de oxigênio não prolonga a sobrevivência desses dois fungos, mesmo em associação com dessecantes; A temperatura de $3{ }^{\circ} \mathrm{C}$ provoca uma ligeira queda no potencial de crescimento de Batkoa sp., porém prolonga a sobrevivência do fungo até 90 dias, independentemente do tratamento. 


\title{
OCCURRENCE, PRODUCTION AND DRY MYCELIUM PRESERVATION OF Batkoa sp. and Furia sp., PATHOGENS OF SPITTLEBUGS PESTS OF PASTURES
}

\author{
Author: LUÍS GARRIGÓS LEITE \\ Adviser: Prof. SÉRGIO BATISTA ALVES
}

\section{SUMMARY}

The fungi Batkoa sp. and Furia sp. although occasionally occurring at epizootic levels in populations of spittlebug pests of pasture and sugarcane, have never been evaluated as to natural incidence level nor biological control potential. This study was designed to evaluate the natural occurrence, in vitro production and dry mycelium preservation of these fungi. Neozygites floridana, a representative of another family of Entomophthorales, was included as a standard in the production studies. The study on natural occurrence was done in Pindamonhangaba county, São Paulo State, from January 22 to February 9, 1998, to evaluate the incidence of Batkoa sp. in the Mahanarva fimbriolata population on pasture of napier grass, and Furia sp. in Deois schach, on Brachiaria sp. pasture. The study on production was done in laboratory conditions with the purpose to develop liquid media for the production of mycelium or hyphal bodies of Batkoa sp. Furia sp. and N. floridana, using as a base a liquid medium for insect tissue culture [Grace's supplemented (HyQ® TNM-FH, \#SH30280.02)], which allowed good growth of the latter pathogen. Finally, the effect of combinations of two desiccants (silica and glycerol) with two oxygen reducers (vacuum and Ageless® ZPT-200) on the preservation of dry mycelium of Batkoa sp. and Furia sp. under temperatures of $3^{\circ} \mathrm{C}$ and $23^{\circ} \mathrm{C}$ was studied. It is concluded that: Batkoa sp. and Furia sp. cause disease in M. fimbriolata and 
D. schach sp. populations, respectively. Furia sp. has higher epizootic potential than Batkoa sp. Batkoa sp., Furia sp. and N. floridana are similar concerning their growth patterns in media with added salts, vitamins and amino acids, as well as in the complete one. The addition of salts to the basic medium causes a significant increase in biomass production of the three fungal species, and higher than that from the addition of vitamins and amino acids. The mixture of the salts $\mathrm{CaCh}_{2} \cdot 2 \mathrm{H}_{2} \mathrm{O}(0,06 \%), \mathrm{KCl}(0,28 \%), \mathrm{MgCl}_{2} \cdot 6 \mathrm{H}_{2} \mathrm{O}$ $(0,16 \%), \mathrm{MgSO}_{4} \cdot 7 \mathrm{H}_{2} \mathrm{O}(0,2 \%), \mathrm{NaHCO}_{3}(0,03 \%)$ and $\mathrm{NaH}_{2} \mathrm{PO}_{4} \cdot \mathrm{H}_{2} \mathrm{O}(0,1 \%)$ afforded higher production of the three fungi than the salts solely evaluated, at the concentration of 0,83\%. MgSO4 can be used as sole salt for the production of Batkoa sp., Furia sp. and N. floridana. These fungi are similar concerning their growth patterns in media with different sources of carbone, but different in media with different sources of nitrogen. The production of the three fungal species is significantly higher in medium containing $2.66 \%$ glucose than in $2.66 \%$ sucrose. The addition of $0.1 \%$ monossacarides to media containing $2.66 \%$ sucrose does not increase significantly biomass production. Yeast extract allows the highest production of Batkoa sp. The concentration of $0.5 \%$ yeast extract is the most suitable for vegetative growth of Batkoa sp. The combination of yeast extract + beef extract + skim milk allows the highest production of Furia sp. The combination of yeast extract + skim milk allows the second highest production of Furia sp., and is the most suitable for mass production due to the lower cost. The $1 \%$ concentration of the mixture of these nitrogen sources is suitable for vegetative growth of Furia sp. The combination of yeast extract + peptone + skim milk allows the highest production of $N$. floridana. The $3 \%$ concentration of the mixture of these nitrogen sources is suitable for the vegetative growth of $N$. floridana. The combination of silica + Ageless ${ }^{\circledR}$ extends the survival of these two fungi formulated as dry mycelium for 90 days, stored at $3^{\circ} \mathrm{C}$ and $23^{\circ} \mathrm{C}$. The use of vacuum to reduce oxygen does not extend the survival of these fungi, even in association with desiccants. Storage at $3^{\circ} \mathrm{C}$ causes a slight decrease in growth potential of Batkoa sp., but it extends fungus survival for 90 days, independent of other treatments. 


\section{INTRODUÇÃO}

O Brasil possui atualmente um rebanho bovino de aproximadamente 180 milhões de cabeças. Para manter esse rebanho, as pastagens ocupam área superior a 180 milhões de ha, o que representa 74\% da área explorada para fins agropecuários (Carvalho, 1995).

As braquiárias (Brachiaria spp.) são as gramíneas mais utilizadas, sendo originárias da África e introduzidas no Brasil na década de 70. Atualmente, ocupam mais de 40 milhões de hectares de pastagens, com mais de $85 \%$ consistindo das espécies $B$. decumbens (cv. Basilisk) e B. brizantha (cv. Marandu). Alguns dos cultivares disponíveis são reconhecidos por serem suscetíveis às cigarrinhas, particularmente $B$. decumbens e $B$. ruziziensis (Argel \& Keller-Grein, 1996).

As cigarrinhas mais importantes para as pastagens pertencem a família Cercopidade, sendo Mahanarva fimbriolata (Fabr., 1787), Deois flavopicta (Stal, 1854), Deois schach (Fabr. 1787) e Zulia entreriana (Berg., 1879) as espécies que causam mais danos para as gramíneas. M. fimbriolata é a principal praga do capim napier (Pennisetum purpureum Schumach.) no leste do Estado de São Paulo, e está se tornando importante para a cana-de-açúcar em todo o Estado.

Esses insetos, além de sugarem a seiva, injetam substâncias tóxicas que produzem o sintoma típico conhecido como "queima das pastagens", podendo resultar em prejuízos de 10 a 100\% dependendo da espécie (Alves, 1985). Os danos são, geralmente, percebidos depois que vastas áreas de pastagens foram completamente destruídas. O comportamento das ninfas, alojando-se no solo, próximo à base do capim, torna inviável a utilização de inseticidas no controle desses insetos. Os pecuaristas preferem métodos alternativos de controle esperando melhorar a eficiência, reduzir a poluição e minimizar os riscos de intoxicação. 
O emprego do fungo Metarhizium anisopliae tem dado bons resultados contra ninfas, geralmente após diversas aplicações sucessivas. Fungos Entomophthorales, embora tenham sido ocasionalmente encontrados desde 1940 em níveis epizoóticos em populações das cigarrinhas das pastagens e cana-de-açúcar (Lepage \& Monte, 1942; Guagliumi, 1969; Guagliumi, 1972; Valerio \& Koller, 1982; Alves, 1986; Batista Filho, 1997; Alves, 1998), não têm sido avaliados e utilizados no controle biológico dessas pragas.

O fungo Batkoa sp. esta associado a espécie $M$. fimbriolata em diversas regiões do Brasil, podendo atacar também Deois sp. e Z. entreriana (Figura 1). Esse patógeno apresenta possibilidade de uso no controle das cigarrinhas devido a elevada eficiência em campo e a possibilidade de produção em meios artificiais (Figura 1). O fungo Furia sp. foi encontrado no Vale do Paraíba, SP, atacando D. schach (Figura 1), D. flavopicta e M. fimbriolata, com elevados níveis de infeção na população das duas primeiras espécies. Apresenta grande potencial de uso para o controle do gênero Deois devido a sua agressividade a esses hospedeiros e facilidade de produção (Figura 1). O fungo Neozygites floridana (Weiser \& Muma) Remaudière \& Keller (Figura 1) foi o padrão incluído nesse estudo devido ao seu potencial no controle de ácaros e aos estudos anteriores já efetuados com esse patógeno.

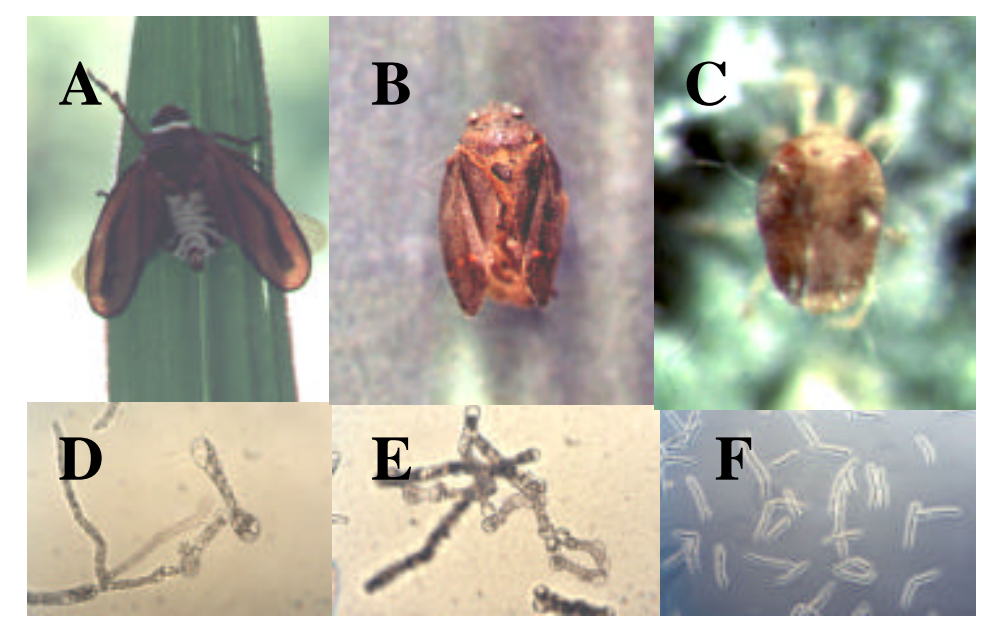

Figura 1 - Mahanarva fimbriolata com Batkoa sp. (A), Deois schach com Furia sp. (B) e Tetranychus urticae com Neozygites floridana (C). Corpos hifais de Batkoa sp. (D), Furia sp. (E) e N. floridana (F) produzidos em meio líquido. 
Os objetivos deste trabalho foram: - Avaliar a ocorrência natural de Batkoa sp. e Furia sp. em populações de cigarrinhas das pastagens; - Avaliar a produção de Batkoa sp., Furia sp. e N. floridana em diferentes meios de cultura; - Avaliar a estabilidade de micélio seco de Batkoa sp. e Furia sp. em diferentes condições de atmosfera e umidade. 


\section{REVISÃO DE LITERATURA}

\subsection{Cigarrinhas das pastagens}

As cigarrinhas ocorrem em todas as pastagens do Brasil, sendo que Deois flavopicta (Stal, 1854) e Deois schach (Fabr. 1787) destacam-se como as espécies de maior abundância nas principais regiões pecuárias (Botelho \& Sá, 1980; Cosenza \& Naves, 1980; Cottas \& Ramiro, 1981a; Melo \& Silveira Neto, 1983).

\subsubsection{Hospedeiros}

As principais plantas hospedeiras de D. flavopicta, no início da década de 70, eram arroz, cana, capim bermuda (Cynodon dactylon), capim colonião (Panicum maximum), capim gordura (Melinis minutiflora), capim jaraguá (Hyparrhenia rufa), pangola (Digitaria decumbens), kikuiu (Pennisetum clandestinum), grama inglesa (Stenotaphum secundatum) e outras gramíneas (Guagliumi, 1972). Após a introdução das Brachiaria spp. no país, essas gramíneas tornaram-se as principais hospedeiras de Deois spp. e Zulia spp. (Gallo et al., 1988). Os níveis de resistência de diversas gramíneas forrageiras à $D$. flavopicta estão apresentados na Tabela 1 .

Mahanarva fimbriolata (Fabr., 1787) geralmente multiplica-se na cultura de

cana ou de napier, atacando as pastagens de Brachiaria spp. que estão nas proximidades. É a principal praga desta gramínea no Vale do Paraíba, devendo se tornar importante para a cana-de-açúcar no Estado de São Paulo, com a adoção do corte mecânico e da técnica de cultivo mínimo. 
Tabela 1. Níveis de resistência de gramíneas forrageiras à cigarrinha-das-pastagens, Deois flavopicta. Ampliado de Cosenza ${ }^{1}$ e extraído de Silveira Neto et al. (1992).

\begin{tabular}{|c|c|c|c|c|}
\hline $\begin{array}{l}\text { Gramíneas forrageiras } \\
\text { Nome Científico }\end{array}$ & Nome comum & & $\begin{array}{l}\text { Nota de } \\
\text { dano }\end{array}$ & $\begin{array}{l}\text { № médio de ninfas por } \\
\text { parcela de } 20 \mathrm{~m}^{2}\end{array}$ \\
\hline $\begin{array}{l}\text { Andropogon gayanus var. bisquamulatus } \\
\text { cv. Planaltina }\end{array}$ & capim-andropogon & & 1 & 0,7 \\
\hline Hyparhhenia hufa & jaraguá & & 1 & 1,5 \\
\hline Cynodon plectostachyus 171 & estrela & & 1 & 1,9 \\
\hline B. radicans $\times$ B. mutica & tangola & & 1 & 2,1 \\
\hline Setaria anceps cv. Kazungula & setaria & $\mathrm{R}$ & 1 & 2,6 \\
\hline Setaria angustifólia & Setaria $*$ & & 1 & 3,1 \\
\hline Panicum maximum cv. Makueni & makueni & & 1 & 5,8 \\
\hline Melinis minutiflora & gordura & & 1 & 13,4 \\
\hline Cenchrus ciliaris CL 1004 & Buffel * & & 1 & 15,3 \\
\hline Brachiaria brizantha & Brizanta & & 1 & 22,5 \\
\hline Cenchrus ciliaris 465 & Buffel * & MR & 1 & 27,2 \\
\hline Brachiaria humidicola & humidicola & & 1 & 163,6 \\
\hline Panicum maximum & colonião & & 2 & 39,5 \\
\hline Panicum maximum & guinezinho & & 2 & 42,9 \\
\hline Brachiaria sp. & braquiaria & & 2 & 43,7 \\
\hline Cenchrus ciliaris 505 & Buffel * & MS & 3 & 41,0 \\
\hline Panicum maximum & green panic & & 3 & 63,1 \\
\hline Cenchrus ciliaris 2953 & buffel $*$ & & 3 & 65,8 \\
\hline Cenchrus ciliaris cv. Biluela & Buffel * & & 3 & 102,9 \\
\hline Brachiaria dyctioneura & braquiaria $*$ & & 3 & 157,5 \\
\hline Digitaria umfolosi & & & 4 & 123,9 \\
\hline Brachiaria decumbens cv. australiana & braquiaria & & 4 & 128,1 \\
\hline Brachiaria decumbens cv. IPEAN & braquiaria & $S$ & 4 & 137,2 \\
\hline Cenchrus ciliaris cv. Texas & Buffel * & & 4 & 139,2 \\
\hline Brachiaria ruziziensis & braquiaria & & 4 & 149,7 \\
\hline
\end{tabular}

Conceituações: 0 - ausência de cigarrinhas; 1 - presença de cigarrinhas; ausência de danos; 2 -pontuação ou listras cloróticas nas folhas; 3 -áreas cloróticas nas folhas; 4 - folhas com a ponta seca; 5 - folhas inteiramente secas; R resistente; MR - moderadamente resistente; MS - moderadamente suscetível; $\mathrm{S}$ - suscetível. * Não exixtem cultivares comerciais.

${ }^{1}$ COSENZA, G.W. Resistência de gramíneas forrageiras à cigarrinha-das-pastagens, Deois flavopicta (Stal, 1854). Brasília: EMBRAPA - CNPAC, v. 7, 1981. 16p. (Boletim de pesquisa). 


\subsubsection{Bioecologia}

As cigarrinhas das pastagens colocam seus ovos nos resíduos vegetais e na superfície do solo. As ninfas eclodem e atacam as raízes superficiais da gramínea, onde permanecem sugando a seiva da planta onde passam por cinco ínstares para atingir a fase adulta. As ninfas são envolvidas por uma espuma branca que lhes protegem contra dessecação e vários inimigos naturais. Os adultos sugam a seiva das folhas e bainhas, e para facilitar o fluxo do líquido, ou para melhorar sua digestibilidade, injetam algumas enzimas que destroem os cloroplastos, causando oclusão nos elementos do floema e gradualmente, a necrose e morte dos tecidos. Isto provoca o sintoma conhecido como queima das pastagens (Guagliumi, 1972).

O ciclo biológico de $D$. flavopicta é de 49 dias, compreendendo 11 dias para a fase de ovo, 34 dias para ninfa e 4 dias para o período de pré oviposição. A longevidade dos adultos é de 10 dias para macho e de 19 dias para fêmea (Alves, 1985). Em um ano podem ocorrer 3 gerações de D. flavopicta na região de Campo Belo, MG, em pastagem com Brachiaria decumbens, cada uma com duração média de 80 dias, havendo sobreposição das gerações (Melo \& Silveira Neto, 1983).

O pico populacional desse inseto na região do Pontal do Paranapanema, SP, ocorre entre dezembro e janeiro (Cottas \& Ramiro, 1981a), sendo que a sua população em B. decumbens, avaliada pelo método do puçá, pode atingir 44 adultos por 100 redadas (Cottas \& Ramiro, 1981b). No município de Campo Belo, MG, as cigarrinhas ocorrem de setembro/outubro a abril/maio com picos de ninfas no final de outubro, e de adultos em novembro, dezembro e início de fevereiro (Melo et al., 1984).

\subsubsection{Condições climáticas favoráveis}

As temperaturas bases estimadas para Z. entreriana e D. flacopicta são de 10,2 e $10,4^{\circ} \mathrm{C}$, sendo o número de graus dias necessários para esses insetos completarem os ciclos de vida é de 523 e 589 , respectivamente (Milanez et al., 1983). A eclosão das ninfas de Z. entreriana ocorre somente em ambiente com umidade relativa de $100 \%$ (Magalhães et al., 1984). Assim, a ocorrência das cigarrinhas depende da reposição de água no solo e temperatura média acima de $18^{\circ} \mathrm{C}$ (Melo et al., 1984). 
Com base em diversas informações, constatou-se que a maior parte do território brasileiro é favorável para a ocorrência das cigarrinhas das pastagens, e que as condições ótimas encontram-se no extremo leste do Estado de São Paulo e na Bahia, bem como extremo norte e no noroeste do país (Silveira Neto et al., 1986).

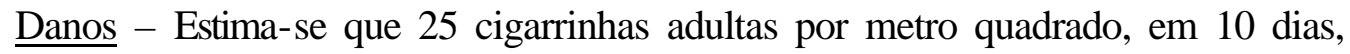
reduzam em $30 \%$ a produção do pasto atacado. Em média, admite-se prejuízo de 15\% na produção de massa verde. O nível de dano econômico aplicado atualmente é de 20 a 25 ninfas grandes por metro quadrado (Almeida et al., 2000).

\subsubsection{Inimigos naturais}

A diversidade de inimigos naturais das cigarrinhas das pastagens é relativamente pequena, e alguns dos principais motivos são:

- ocorrência cíclica de outros insetos fitófagos nessa cultura (Gallo et al., 1988), os quais poderiam também servir de hospedeiros aos insetos entomófagos;

- estrutura relativamente baixa e exposta da Brachiaria sp., oferecendo poucos abrigos aos inimigos naturais, como se constatou para as aranhas (Rinaldi, 1995);

- alta competitividade da cultura, impedindo o crescimento de plantas que fornecem alimentos para adultos de muitas espécies de parasitos e de alguns predadores;

- comportamento das ninfas das cigarrinhas, envolvendo-se em uma espuma que lhe protege contra a ação de alguns inimigos naturais e

- hábito alimentar desses insetos, como sugadores, protegendo-os contra a ação de virus, bactérias e protozoários, os quais necessitam de serem ingeridos para causarem doença.

Entretanto, as cigarrinhas têm sido naturalmente controladas em algumas regiões devido a eficaz atuação de alguns dos agentes benéficos, como dos fungos entomopatogênicos, os quais estão geralmente associados a epizootias que dizimam a população da praga. Existem diversos fungos associados as cigarrinhas das pastagens, porém, a maioria dos trabalhos de controle microbiano desses insetos se referem ao uso de Metarhizium anisopliae. Esse fungo foi testado pela primeira vez em pastagem, por Guagliumi (1971), tendo em vista o combate de Aeneolamia sp. em capim pangola. Os resultados obtidos até hoje apresentam-se ainda bastante dependentes da formulação do patógeno, das condições da cultura e do clima (Ramiro \& Cottas, 1979; Cottas \& Ramiro, 
1981b; Alves, 1986; Alves \& Lecuona, 1996). Assim, outros fungos também devem ser avaliados, como os Entomophthorales, geralmente encontrados causando até $80 \%$ de infecção na população desses inseto.

\subsection{Fungos Entomophthorales}

Os fungos Entomophthorales, juntamente com os Mucorales, pertencem a classe Zygomycetes, sendo as espécies da primeira ordem geralmente associadas a insetos, e da segunda, a vegetais. Os zigomicetos são organismos estritamente terrestres, que possuem micélio não septado e formam estruturas de repouso denominadas zigósporos (sexuada) ou azigósporos (assexuada). Formam também esporângio que se constitui em uma estrutura de parede dupla, dentro da qual são formados os esporos. Os esporângios de Entomophthorales são geralmente denominados de conídios, pois são monospóricos e assexuados, apresentando ainda a característica de serem ejetados violentamente quando amadurecidos (Webster, 1980). Os Entomophthorales podem formar rizóides, os quais prendem o hospedeiro no substrato, sendo caracterizados ainda por colonizar, inicialmente, partes não vitais do hospedeiro, permitindo a sua sobrevivência por maior período de tempo (Humber, 1984b). O gênero Conidiobolus não produz rizóides e mata o hospedeiro muito rapidamente pela liberação de toxinas. Esse gênero abrange organismos de solo, caracterizados como saprofíticos e oportunistas, pois são frequentemente isolados de insetos já atacados por outras espécies de Entomophthorales, reproduzindo-se em uma grande diversidade de substratos.

\subsubsection{Evolução taxonômica}

As formas ancestrais de Entomophthorlaes devem ter sido quase indenticas às espécies de Conidiobolus. Os primeiros Entomophthorales eram provavelmente saprofíticos, crescendo em restos de folhas ou outros detritos. Ao evoluírem, passaram para fungos facultativos, com patogenicidade para organismos de solo. A diferenciação de Entomophthorales para Mucorales iniciou-se com o desenvolvimento da habilidade de ejetar conídios (Humber, 1984b). 
A primeira espécie encontrada de Entomophthorales foi detectada atacando Musca domestica e identificada por Cohn (1855) como Empusa muscae, conforme histórico elaborado por Macleod (1963). Um ano depois, Fresenius (1856) propôs a mudança desse gênero para Entomophthora afirmando que Empusa já era uma denominação dada para um gênero de orquídea, sendo portanto homônimos.

Macleod \& Muller-Kogler (1970) relataram que Cohn (1877) identificou também a espécie Tarichium megaspermum, dando-lhe essa denominação por encontrar apenas esporos de resistência dentro do hospedeiro. Brefeld (1877) verificou que uma espécie de Entomophthorales, encontrada em 1870 atacando Pieris brassicae, além de produzir esporos de resistência, produzia também conídios sobre o hospedeiro, sendo originados por conidióforos ramificados. Esse autor denominou essa espécie de Entomophthora radicans e sugeriu o uso desse gênero para as espécies com conidióforos ramificados e Empusa para as espécies com conidióforos simples, devendo as espécies de Tarichium que produzissem também conídios serem transferidas para um desses gêneros dependendo do conidióforo. Dois anos após, Peck², citado por Thaxter (1888) e Bem-ze'ev \& Kenneth (1982), criou o gênero Massospora.

Macleod \& Muller-Kogler (1970) relataram que Giard (1879) sugeriu o uso de Entomophthora como gênero único enquanto Nowakowski (1884) propôs a permanência dos gêneros Empusa e Entomophthora, afirmando que o primeiro caracterizava-se pela presença de conidióforos simples e pela formação de zigósporos, e o segundo pela presença de conidióforos ramificados, formação de rizóides, cistídios e zigósporos. Esse último autor criou ainda o gênero Lamia para as espécies com características intermediárias, diferindo de Empusa pela presença de cistídios.

Nesse mesmo período, Brefeld ${ }^{3}$, citado por Thaxter (1888), criou o gênero Conidiobolus enquanto que Witlaczil ${ }^{4}$, citado por Remaudière \& Keller (1980), descreveu a espécie Neozygites aphidis, citando a doença como causada por um protozoário gregarídeo.

Thaxter (1888) enfatizou a prioridade de nomes e propôs a volta de Empusa como gênero único. Foram criados os subgêneros Empusa, Entomophthora e

\footnotetext{
${ }^{2}$ PECK, C.H. Massospora cicadina n. g. et sp. 31st Rep. of State Botanist of N. Y., p. 44, 1879.

${ }^{3}$ BREFELD, O.A. Conidiobolus utriculosus und C. minor. Botanische Untersuchungen ueber Schimmelpilze, Heft VI, p. 35, Leipzig (1884). Plates.

${ }^{4}$ WITLACZIL, E. Neozygites aphidis, eine neue Gregarine. Arch. Mikr. Anat. v. 24, p. 599-603. 1885.
} 
Triplosporium, sendo este último caracterizado pelos conídios primários fuliginosos, um tipo particular de capiloconídio, e pela formação isogâmica de zigósporos.

Cavara $^{5}$ e Riddle ${ }^{6}$, citados por Macleod (1963), propuseram a permanência de Empusa e Entomophthora, afirmando que o primeiro era polinucleado e o segundo, mononucleado. Olive (1906) concordou com essa diferença mas ressaltou que esse fato não justificava a existência de dois gêneros e propôs o uso apenas do gênero Empusa. Goldstein (1927) rejeitou essa proposta e sugeriu a permanência dos gêneros Empusa e Entomophthora tendo como base as diferenças morfológicas e citológicas. Anteriormente a isso, foi criado o gênero Culicicola como o objetivo de substituir o gênero Lamia (Nieuwland ${ }^{7}$, citado por Remaudière \& Keller, 1980).

Nas décadas seguintes houve concordância quanto ao uso de um gênero único para Empusa e Entomophthora, mas discordância na escolha do gênero a ser adotado. Assim, um grupo manteve a denominação Empusa (Fitzpatrick, 1930; Vegas, 1939, Macleod, 1956) enquanto que outro preferiu Entomophthora (Kevorkian, 1937; Hall \& Dunn, 1957; Hall \& Bell, 1962) até que Batko (1964a, b, c, d) apresentou uma tentativa de esclarecimento na sistemática de Entomophthorales propondo a existência de 5 gêneros: Entomophthora Fres. 1856, Triplosporium (Thaxter 1888) Batko 1964, Culicicola Nieuwl. 1916 (=Lamia Nowak. 1883), Zoophthora Batko 1964 e Entomophaga Batko 1964.

Batko \& Weiser (1965) criaram mais um gênero, Strongwelsea, e Batko (1966) distribuiu as espécies de Zoophthora em 4 sub-gêneros: Zoophthora Batko 1964, Erynia Nowak.1881, Pandora Batko 1966 e Furia Batko 1966.

Remaudière \& Keller (1980) descobriram que a espécie $N$. aphidis, citada como gregarídeo, tratava-se de um fungo Entomophthorales e apresentava as mesmas descrições do subgênero Triplosporium criado por Thaxter em 1988. Isso levou Remaudière \& Keller (1980) a propor a substituição do gênero Triplosporium por Neozygites alegando prioridade de nomes. Esses autores propuseram ainda:

- classificar Tarichium como gênero incerto, já que o mesmo refere-se a apenas à fase de esporo de resistência do fungo;

\footnotetext{
${ }^{5}$ CAVARA, D.F. I nuclei delle Entomophthoreae in ordine alla filogenesi di queste piante. Boll. Soc. botan. ital., v. 12, p. 55-60. 1899.

${ }^{6}$ RIDDLE, L.W. On the cytology of the Entomophthoraceae. Proc. Am. Acad. Arts Sci., v. 42, p. 177-198. 1907.

${ }^{7}$ NIEUWLAND, J.A. Critical notes of new and old genera of plants VII. The Amer. Midl. Nat., v. 4, p. $374-$ 378, 1916.
} 
- incluir Entomophaga no gênero Conidiobolus;

- incluir Culicicola no gênero Entomophthora;

- aceitar os gêneros Zoophthora e Erynia, conforme proposto por Remaudière \& Rennebert (1980);

- classificar Strongwellsea como sinônimo de Erynia.

Humber (1981) considerou a sistemática de Entomophthorales ainda controvertida e apresentou uma nova proposta de classificação filogenética com base em valores morfológicos e outros critérios taxonômicos. Assim, propôs a permanência de Entomophaga e Strongwellsea e considerou Tabanomyces sinônimo do gênero nematófago, Meristacrum. Propôs ainda transferir o gênero Zoophthora para Erynia, descrito em 1881, alegando prioridade de nome e outros embasamentos taxonômicos. Ben-ze'ev \& Kenneth (1982) propuseram a distribuição das espécies de Conidiobolus nos sub-gêneros Conidiobolus, Capillidium e Delacroixia.

O gênero Eryniops foi criado por Humber (1984a) para incluir as espécies com características intermediárias entre Entomophaga e Erynia/Zoophthora, diferenciando do primeiro gênero pelos conídios alongados, menor número de núcleos por conídios e pela formação de conídios secundário; e de Erynia/Zoophthora pelo número de núcleos por conídio e pela estrutura da parede.

Seguindo a classificação filogenética, Humber (1989) reconheceu 6 famílias: Entomophthoraceae, Completoriaceae (fam. Nov.), Ancylistaceae, Meristacraceae (fam. Nov.), Neozygitaceae e Basidiobolaceae. Elevou os 4 sub-gêneros batkonianos de Zoophthora para nível de gênero: Zoophthora, Erynia, Furia e Pandora. Criou o gênero Batkoa, anteriormente considerado como Entomophaga, e apresentou uma emenda para separar o gênero Conidiobolus de Entomophaga e Batkoa. Esse autor delimitou os gêneros de Entomophthorales com base nos seguintes caracteres:

1. Primários (conídos):

- morfologia do conídio e papila;

- número de núcleos;

- estado uni ou bitunicado da parede; modo de descarga e

- morfologia dos conidióforos e célula conidiógena.

2. Secundários:

- formação e morfologia dos rizóides e/ou cistídios; 
- $\quad$ tipo de conídio secundário formado;

- características dos esporos de resistência (cor, decoração, etc.);

- células vegetativas: com ou sem parede (protoplastos) e

- patobiologia: modo de ação, afinidade com o hospedeiro, comportamento geral, etc.

Keller (1991) propôs a permanência somente dos gêneros Conidiobolus, Entomophaga, Entomophthora, Erynia, Eryniopsis, Neozygites, Strongwellsea, Zoophtora e Tarichium, afirmando que os mesmos podem ser caracterizados inequivocamente com base nos seguintes critérios:

Nível genérico:

- características de núcleo;

- modo de descarga do conídio primário;

- número de núcleos por conídios;

- forma do conídio primário e secundário, e modo de formação do conídio secundário.

Nível de grupo:

- protoplastos: presença/ausência e modo de multiplicação;

- forma dos corpos hifais;

- morfologia dos conídios

- rizóides: presença/ausência e morfologia;

- cistídio: presença/ausência e morfologia;

- modo de formação dos esporos de resistência e germinação;

- forma do conídio secundário.

Nível de espécie:

- conídio e esporo de resistência: dimensão, forma e aspectos especiais;

- núcleo: tamanho e número;

- gama de hospedeiros.

Atualmente são reconhecidos mais de 10 gêneros (Tabela 2). Pandora é o gênero com maior número de espécies descritas (16) dentro da família Entomophthoraceae, seguido do gênero Zoophthora (14), Erynia e Furia (12), Entomophthora (11), Entomophaga (10), Batkoa (5) e Eryniopsis (3). Quanto ao gênero Neozygites, foi relatado por Keller (1997) apresentando 15 espécies já descritas. O gênero Tarichium contém várias espécies, as quais são conhecidas apenas pelos esporos de resistência. Mais recentemente, 
Steinkraus et al. (1998) descreveu um novo gênero, Orthomyces, contendo apenas uma espécie (O. aleyrodis).

Batkoa (= Empusa, = Emtomophthora, = Conidiobolus, = Entomophaga) aproxima-se do gênero Entomophaga, diferenciando principalmente pela formação de rizóides. Furia sp. (= Erynia) aproxima-se do gênero Erynia sp., diferenciando principalmente pela maior abundância de rizóides (Humber, 1989). 
Tabela 2. Fungos patogênicos a invertebrados pertencentes a 3 famílias e vários gêneros da Ordem Entomophthorales, com seus hospedeiros (Balazy, 1981; Balazy \& Wisniewski 1984; Humber, 1989; Keller, 1987; Keller, 1991; Steinkraus et al., 1998; Wheeler, 1988).

\begin{tabular}{|c|c|c|}
\hline Família & Gênero & Hospedeiro \\
\hline Ancylistaceae & Conidiobolus & $\begin{array}{l}\text { Coleoptera, Diptera, Homoptera, } \\
\text { Hymenoptera, Lepdoptera, Orthoptera, } \\
\text { Thysanoptera }\end{array}$ \\
\hline \multirow[t]{10}{*}{ Entomophthoraceae } & $\begin{array}{l}\text { Erynia lato sensu } \\
\text { (Erynia, Furia, Pandora) }\end{array}$ & $\begin{array}{l}\text { Coleoptera, Dermaptera, Diptera, } \\
\text { Hemiptera, Homoptera, Hymenoptera, } \\
\text { Lepidoptera, Trichoptera }\end{array}$ \\
\hline & Zoophthora & 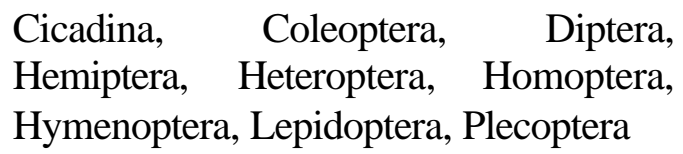 \\
\hline & Entomophthora & $\begin{array}{l}\begin{array}{l}\text { Diptera, Heteroptera, } \\
\text { Nematocera, } \\
\text { Thysanoptera }\end{array}\end{array}$ \\
\hline & Eryniopsis & Coleoptera, Diptera \\
\hline & Orthomyces & Homoptera \\
\hline & Batkoa & Diptera, Homoptera \\
\hline & Entomophaga & $\begin{array}{l}\text { Arachnida, } \\
\text { Homoptera, } \\
\text { Lepidoptera, Nematocera, Orthoptera, } \\
\text { Saltatoria }\end{array}$ \\
\hline & Massospora & Homoptera \\
\hline & Strongwellsea & Diptera \\
\hline & Tarichium & Acari, Coleoptera, Lepidoptera \\
\hline Neozygitaceae & Neozygites & Acari, Homoptera, Thysanoptera \\
\hline
\end{tabular}




\subsubsection{Ocorrência e especificidade}

Fungos Entomophthorales já foram considerados por Alves (1998) como bioinseticidas do futuro, pois têm sido constatados causando epizootias em populações de insetos e ácaros, com níveis de infecção geralmente acima de 50\% (Tabela 3).

Lepage \& Monte (1942) apresentaram o primeiro relato de Entomophthorlaes atacando cigarrinha das pastagens quando descreveram a ocorrência de Empusa sp. na população de D. flavopicta. Esse fungo já foi encontrado nos Estados do Mato Grosso, Minas Gerais, Bahia, Sergipe, São Paulo e Distrito Federal atacando diferentes espécies das cigarrinhas das pastagens (Aeneolamia sp., Deois sp. e Zulia sp.) e da cana de açúcar (M. fimbriolata e $M$. posticata), com níveis de infecção na população do hospedeiro até mesmo superior a 80\% (Lepage \& Monte, 1942; Guagliumi, 1969; Guagliumi, 1972; Valerio \& Koller, 1982; Alves, 1986). Batista Filho et al. (1997) e Alves (1997) relataram pela primeira vêz Batkoa sp. atacando a cigarrinha $M$. fimbriolata.

Tabela 3. Fungos Entomophthorales e níveis de infecção na população de diferentes hospedeiros

\begin{tabular}{lcll}
\hline Espécie & $\begin{array}{c}\text { Infecção } \\
(\%)\end{array}$ & Hospedeiro & Autores \\
& 42 & Amrasca biguttula & Villacarlos \& Keller (1997) \\
\hline Batkoa amrascae & 83 & Acyrthosiphon pisum & Wilding (1975) \\
Entomophthora spp. & 90 & Delia antiqua & Carruthers et al. (1985) \\
E. muscae & 100 & Heliothis zea & Hamm (1980) \\
Entomophaga aulicae & 72 & Lymantria dispar & Hajek et al. (1996) \\
E. maimaiga & 81 & Oligonychus pratensis & Dick \& Buschman (1995) \\
Neozygites adjarica & 71 & Tetranychus urticae & Brandenburg \& Kennedy (1982) \\
N. floridana & 65 & Phenacoccus herreni & Delalibera Junior et al. (1997) \\
N. fumosa & 82 & Delia radicum & Lamb \& Foster (1986) \\
Strongwellsea castrans & 55 & Empoasca sp. & Galaini-Wraight et al. (1991) \\
Zoophthora radicans & 100 & Hypera posticata & Morris et al. (1996) \\
Z. phytonomi & & & \\
\hline
\end{tabular}


O gênero Neozygites tem sido encontrado atacando pequenos artrópodos como cochonilhas, pulgões, tripes e ácaros (Keller, 1991), estando Neozygites floridana (Weiser \& Muma) Remaudière \& Keller relacionada a diversas espécies de ácaros (Keller, 1997). Weiser \& Muma (1966) relataram essa espécie, como Entomophthora floridana, em população do ácaro texano do citros, Eutetranychus banksi. Logo em seguida o gênero foi tranferido para Triplosporium (Weiser, 1968) e, alguns anos depois, para Neozygites (Remaudière \& Keller, 1980). A primeira ocorrência dessa espécie em Teranychus urticae foi registrada por Carner \& Canerday (1970), quando verificaram uma epizootia em lavoura de algodão no Alabama. Esse fungo também já foi constatado em população de Oligonychus hondoensis no Japão (Nemoto \& Aoki, 1975) e em população do ácaro verde da mandioca, Mononychellus tanajoa, no nordeste do Brasil (Delalibera Junior et al., 1992).

Fungos Entomophthorales podem atacar grande diversidade de insetos e ácaros, porém cada isolado é geralmente específico para determinados grupos de hospedeiros. Conídios de N. fresenii, geralmente encontrada em Aphis fabae e não em Acyrthosiphon pisum, germinaram na cutícula de cada uma das epécies de afídeo, formando apressórios e fixando o tubo germinativo na cutícula dos hospedeiros. Porém, o fungo só penetrou na cutícula de $A$. fabae, sugerindo que o mecanismo de barreira ocorreu na cutícula do hospedeiro A. pisum (Brobyn \& Wilding, 1977). Um isolado de Z. radicans encontrado em Empoasca fabae apresentou elevada patogenicidade contra Empoasca kraemeri, tendo sido introduzido com sucesso na população dessa espécie (Leite,1991).

\subsubsection{Ciclo biológico e potencial epizoótico}

Os fungos Entomophtorales são organismos específicos e, portanto, necessitam causar altos níveis de mortalidade do hospedeiro, uma vez que dependem apenas do mesmo para se reproduzir e disseminar. Para isso, esses patógenos desenvolveram grande potencial epizoótico utilizando estratégias peculiares ao longo do seu ciclo de vida, quais sejam: 1) reconhecem a adequabilidade do substrato antes de iniciarem o processo de infecção; 2) germinam e penetram a cutícula em curto período de tempo (4 horas); 3) iniciam a doença com poucos conídios por hospedeiro (geralmente menos de 10); 4) aparentemente induzem o hospedeiro infectado a subir nas partes mais altas das plantas ou abrigo, onde o patógeno possa promover melhor disseminação dos conídios; 5) fixam o hospedeiro no substrato por 
meio de rizóides ou induzem os mesmos a se fixarem por si próprio antes de morrerem; 6) matam o hospedeiro no entardecer, próximo às melhores condições para o desenvolvimento da doença, as quais iniciam-se a noite; 7) iniciam a conidiogênese em curto período (4 horas) após o início do orvalho; 8) ejetam balisticamente conídios primários; 9) produzem conídios secundários ou capiloconídios, os quais permitem extender a sobrevivência do patógeno; 10) produzem esporos de resistência, os quais permitem ao fungo sobreviver por um ano ou mais.

1) Reconhecimento do hospedeiro. Ao atingir o hospedeiro suscetível o fungo tende a emitir um tubo germinativo que resulta em penetração no mesmo. Caso o conídio se fixe em um hospedeiro ou substrato não adequado como região muito esclerotizada do hospedeiro, o fungo tende a produzir conídios secundários ou capiloconídios, os quais são também infectivos, aumentando a chance do patógeno fixar-se em um substrato adequado (Leite et al., 1996b). Para o reconhecimento do hospedeiro, o fungo pode utilizar sinais químicos (quimiotropismo) e topográfico (tigmotropismo) provenientes da cutícula (Hajek \& St. Leger, 1994).

2) Virulência. Esses patógenos iniciam rapidamente a germinação e penetração no hospedeiro, completando essas fases geralmente em 2 e 4 horas, respectivamente (Leite et al., 1996b; Leite et al., 1996c; Oduor et al., 1996b). Para Entomophaga maimaiga sobre Lymantria díspar, a infecção ocorre dentro de um período médio de 8,7 horas a $25^{\circ} \mathrm{C}$ (Hajek et al., 1993). Esse curto período para iniciar a penetração é de extrema importância para o processo epizoótico, pois permite ao fungo promover a infecção em períodos limitados (curtos) de umidade e temperatura favoráveis.

3) Patogenicidade. O desenvolvimento da doença no inseto ou ácaro ocorre com um pequeno número de conídios por hospedeiro, geralmente abaixo de 10 (Papierok \& Wilding, 1979; Milner \& Soper, 1981; Wraight et al. 1990), chegando a apenas um conídio que foi a CL50 determinada para o fungo N. floridana sobre T. uticae (Oduor et al., 1997). Essa elevada patogenicidade também compensa o pequeno número de conídios produzidos por esses fungos em relação aos hifomicetos (Leite et al., 1996d ).

4) Comportamento de febre. Insetos infectados com Entomophthorales são geralmente induzidos a escalar as partes mais elevadas das plantas ou abrigo antes de morrer, na tentativa de elevar a temperatura de seus corpos pela exposição dos mesmos a radiação solar e, consequentemente, inativar o patógeno (Steinhaus, 1949; Carruthers et al., 
1992; Watson et al., 1993). Essa reação é conhecida como comportamento ou síndrome de febre, pois existem indicações de que o hormônio prostaglandina (associado a indução de febre em humano) pode ser um componente do sistema imunológico do inseto (StanleySamuelson et al., 1991), induzindo vários artrópodos a exibirem esse comportamento quando injetado nos mesmos (Casterlin \& Reynolds, 1979; Cabanac \& Le Guelte, 1980). O díptero $M$. domestica infectado com Entomophthora muscae apresentou esse comportamento após o $2^{\mathfrak{Q}}$ e $3^{\mathrm{O}}$ dia de incubação do patógeno, conseguindo inativar o fungo somente quando exposto a temperaturas acima de $35^{\circ} \mathrm{C}$, por pelo menos quatro horas (Watson et al., 1993).

Esse comportamento contribui para a caracterização de Entomophthorales como patógenos de clima temperado, com emperaturas ótimas em torno de $20^{\circ} \mathrm{C}$ ou abaixo (Hall \& Papierok, 1982). Nessas condições, o fungo possui grande vantagem já que sobrevive às temperaturas mais altas, geralmente próximas de $35^{\circ} \mathrm{C}$, utilizando esse comportamento do inseto para atingir as partes mais elevadas das plantas, onde pode promover melhor disseminação dos esporos.

5) Rizóides. Esse agrupamento de hifas fixa o hospedeiro no substrato, possuindo grande importância para o desenvolvimento epizoótico já que dificulta a perda do inóculo pela ação da chuva e vento. Algumas espécies como Entomophaga grylli, patógeno de gafanhotos, não formam rizóides, porém o hospedeiro é induzido a prender-se no substrato antes de morrer, com o auxílio das pernas (Carruthers et al., 1997).

6) Sincronismo de mortalidade. A morte do hospedeiro pode ocorrer dentro de um período pós-infecção que pode variar de 2 a 3 dias para o ácaro-verde-da-mandioca, $M$. tanajoa, infectado com $N$. floridana (Oduor et al., 1997), e de 5 a 6 dias para M. domestica infectado com E. muscae (Watson et al., 1993). Larvas do geometrídeo Lambdina fiscellaria, infectadas com E. aulicae, morrem dentro do período de 75 a 90 horas após a infecção, a $15^{\circ} \mathrm{C}$ (Mcdonald \& Nolan, 1995). O hospedeiro morre geralmente ao entardecer, pouco antes do escurecimento. Esse sincronismo de mortalidade permite que o fungo amadureça nas próximas 8 horas e inicie a conidiogênese logo após o início das condições favoráveis de umidade e temperatura (Milner et al., 1984). E. maimaiga inicia a conidiogênese no corpo de L. dispar 17 horas após a morte do hospedeiro, ejetando os conídios primários nas proximidades (Hajek et al., 1990). 
7) Conidiogênese. Em condições favoráveis de umidade relativa, ocorre a conidiogênese do patógeno juntamente com a formação de cistídios. O fungo inicia a conidiogênese rapidamente, geralmente em 4 a 6 horas após o aparecimento de orvalho (Leite et al., 1996a; Oduor et al., 1996a). Assim, esse período mais 4 horas para iniciar a infecção permite ao patógeno desenvolver a doença em níveis epizoóticos mesmo em períodos de estiagem, com um mínimo de 9 horas de orvalho por dia (Milner, et al., 1982; Galaini-Wraight et al., 1991; Leite, 1991) .

8) "Chuva" de conídios. Os conídios são ejetados na maioria das espécies por eversão da papila, alcançando distâncias de até 3,75 cm do cadáver (Six \& Mullens, 1996). Isso contribui para a disseminação do agente nas proximidades e longas distâncias com o auxílio do vento, na forma conhecida como "chuva" de conídios. Adultos alados dos insetos, infectados com o patógeno, também contribuem para a disseminação (Wraight \& Roberts, 1987) e principalmente introdução do agente (Wilding, 1981).

9) Conídios secundários ou capiloconídios. A produção de conídios secundários e capiloconídos contribui para melhorar a sobrevivência do patógeno, já que os conídios primários possuem curto período de vida, de 14 dias para Pandora neoaphidis (Brobyn et al., 1985) e 1 hora para $N$. floridana (Oduor et al., 1986a). Além disso, capiloconídios são mais resistentes às condições adversas que conídios primários, podendo sobreviver por até 1 mês para Z. radicans a $50 \%$ de umidade, e $20^{\circ} \mathrm{C}$ (Uziel \& Kenneth, 1986) e 10 dias para N. floridana.

10) Esporos de resistência. Esporos de resistência de E. maimaiga, patógeno de L. dispar, podem persistir por até 6 anos, sendo o solo o principal reservatório (Weseloh \& Andreadis, 1997). Com a chegada das estações chuvosas e aumento da umidade no solo, os esporos de resistência germinam, resultando na formação de focos primários da doença. Assim, insetos que passam parte de seu ciclo no solo tornam-se mais predispostos a atuação do fungo durante a formação do foco inicial da doença, em áreas onde o patógeno ocorre anualmente. 


\subsubsection{Fatores limitantes}

As epizootias de fungos entomopatogênicos, em geral, são influenciadas pelos fatores físicos do ambiente, especialmente a temperatura e umidade, e pelos fatores relacionados ao hospedeiro e ao próprio fungo.

\section{$\underline{\text { Temperatura }}$}

A temperatura influencia epizootias de fungos, especialmente Entomophthorales, pois segundo Carruthers \& Soper (1987) pode afetar três estágios de desenvolvimento dos patógenos: formação e descarga dos conídios; germinação dos conídios e penetração do fungo no hospedeiro, além do crescimento vegetativo dentro do hospedeiro.

Os fungos Entomophthorales são organismos predominates de clima temperado, com temperaturas ótimas para o desenvolvimento abaixo ou em torno de $20^{\circ} \mathrm{C}$ (Hall \& Papierok, 1982). Conforme as Tabelas 4, 5 e 6, as faixas de temperatura ótima para muitas espécies é de 10 a $20^{\circ} \mathrm{C}$ ou 20 a $25^{\circ} \mathrm{C}$, sendo o limite inferior em torno de $5^{\circ} \mathrm{C}$, e superior de $33^{\circ} \mathrm{C}$. Para o fungo Z. radicans, a faixa de temperatura de 15 a $25^{\circ} \mathrm{C}$ foi considerada favorável para o desenvolvimento epizoótico do patógeno (Leite et al., 1996d). 
Tabela 4. Faixas de temperaturas $\left({ }^{\circ} \mathrm{C}\right)$ ótimas para germinação, crescimento e conidiogênese de fungos Entomophthorales.

\begin{tabular}{lllll}
\hline Fungo & Germ. & Cresc. & Conidiog. & Referência \\
\hline $\begin{array}{l}\text { Conidiobolus obscurus } \\
\text { Entomophthora gammae }\end{array}$ & 21,0 a 26,7 & & & Wilding (1970) \\
E. muscae & 20,0 a 25,0 a 25,0 & & 21,0 a 26,7 & Newman \& Carner (1975) \\
$\begin{array}{l}\text { E. planchoniana } \\
\text { Entomophaga maimaiga }\end{array}$ & 20,0 a 25,0 & & 10,0 a 27,0 & Carruthers \& Haynes (1986) \\
Erynia conica & 10,0 a 20,0 & & 10,0 a 20,0 & Milner (1981) \\
E. neoaphidis & & & Hajek et al. (1990) \\
Neozygites floridana & 13,0 a 28,0 & & 10,0 a 20,0 & Nadeau et al. (1995) \\
Zoophthora aphidis & & 15,0 a 25,0 & Milner (1981) \\
Z. phalloides & & 18,0 a 23,0 & Oduor et al. (1996a) \\
Z. radicans & 20,0 a 25,0 & & Wilding (1970) \\
\hline
\end{tabular}

Tabela 5. Temperaturas $\left({ }^{\circ} \mathrm{C}\right)$ limites superiores para germinação, crescimento e conidiogênese de fungos Entomophthorales.

\begin{tabular}{lcccl}
\hline Fungo & Germ. & Cresc. & Conidiog. & Referência \\
\hline Entomophthora gammae & & 32,2 & Newman \& Carner (1975) \\
E. grylli & 33,0 a 35,0 & 35,0 & Carruthers et al. (1992) \\
E. muscae & 32,0 a 35,0 & & Watson et al. (1993) \\
Zoophthora radicans & 34,0 & 34,0 & 32,0 & Mcguire et al. (1987a) \\
\hline
\end{tabular}


Tabela 6. Temperaturas $\left({ }^{\circ} \mathrm{C}\right)$ limites inferiores para germinação, crescimento e conidiogênese de fungos Entomophthorales.

\begin{tabular}{lcccl}
\hline Fungo & Germ. & Cresc. & Conidiog. & Referência \\
\hline Conidiobolus obscurus & 5,0 & 5,0 & & Wilding (1970) \\
Entomophthora gammae & 10,0 & & 10,0 & Newman \& Carner (1975) \\
E. planchoniana & & 5,0 & Milner (1981) \\
Entomophaga maimaiga & & 2,0 & Hajek et al. (1990) \\
Erynia neoaphidis & & 5,0 & Milner (1981) \\
Neozygites floridana & & & 6,0 & Kenneth et al. (1972) \\
Zoophthora aphids & 5,0 & 5,0 & & Wilding (1970) \\
Z. phalloides & & & 4,0 & Glare et al. (1986) \\
Z. radicans & & & 5,0 & Leite et al. (1996d) \\
\hline
\end{tabular}

\section{$\underline{\text { Umidade }}$}

Os fungos entomopatogênicos são afetados pela umidade relativa nos seus estágios de desenvolvimento que ocorrem externamente no hospedeiro, quais sejam: formação e descarga dos conídos, e germinação dos mesmos. Muitas espécies de Entomophthorales requerem umidade relativa (UR) de 98 a 100\% para a germinação e conidiogênese (Tabela .7). As UR de 89,9; 91,2; 94,8; 97,5 e 99,1 provocaram inibição na produção de conídios de Zoophthora sp. de 100, 95, 90, 70 e 20\% respectivamente, em relação a condição ótima de $100 \%$ de umidade (Millstein et al., 1983).

E. muscae pode produzir e ejetar os conídios em UR de até 50\%, utilizando para isso apenas a umidade saturada presente no cadáver. Além disso, esporos desse fungo e E. planchoniana são revestidos por citoplasma rico em lipídeos após a ejeção, o que lhes confere proteção contra a dessecação, permitindo a germinação dos mesmos em baixa UR, na faixa de 0 a $100 \%$ (Kramer, 1980; Holdom, 1984). 
Tabela 7. Faixa de umidades relativas (\%) favoráveis para a germinação e conidiogênese de fungos Entomophthorales.

\begin{tabular}{lccl}
\hline Fungo & Germ. & Conidiog. & Referência \\
\hline Conidiobolus obscurus & & 97,5 a 100 & Wilding (1969) \\
Entomophthora gammae & 98,0 a 100 & 80,0 a 100 & Newman \& Carner (1975) \\
E. muscae & 0 a 100 & 50,0 a 100 & Kramer (1980) \\
E. planchoniana & 0 a 100 & 98,0 a 100 & Holdom (1984) \\
Entomophaga maimaiga & 100 & 90,0 a 100 & Hajek et al. (1990) \\
Erynia sp. & & 91,5 a 100 & Millstein et al. (1982) \\
E. neoaphidis & & 97,5 a 100 & Wilding (1969) \\
Neozygites floridana & 98,2 a 100 & 98,2 a 100 & Oduor et al. (1996a) \\
Zoophthora phalloides & 98,0 a 100 & 98,0 a 100 & Glare et al. (1986) \\
\hline
\end{tabular}

Muitos Entomophthorales, apesar de exigirem umidade elevada, são provavelmente menos dependentes desse fator para ocorrência natural do que muitos hifomicetos, pois apenas uma pequena parte do ciclo desses patógenos ocorre externamente no hospedeiro, exposto ao ambiente. Apenas $15 \%$ do ciclo de $N$. floridana ocorre na parte externa do hospedeiro, durante a extrusão, início de conidiogênese, adesão, germinação e penetração, comparado com 66,6\% do ciclo de Beauveria bassiana (Figura 2). Epizootias de Beauveria spp. e especialmente Metarhizium spp. têm sido mais associadas a insetos de solo ou de outros ambiente como bainhas de folhas e casca de árvores, onde a umidade é mantida por um maior período de tempo.

A chuva é um fator favorável ao patógeno desde que ocorra em baixa intensidade. Segundo Alves (1998), chuvas muito intensas e contínuas, durante a ocorrência dos focos primários das doenças (fase pré-epizoótica), prejudicam a disseminação do patógeno e o desenvolvimento da epizootia. Para N. fumosa, o desenvolvimento epizoótico do patógeno em população de Phenacoccus manihot esteve mais relacionado a frequiência de chuva do que a precipitação total (Lê-ru \& Iziquel, 1990). 


\section{Neozygites floridana}

\section{Beauveria bassiana}

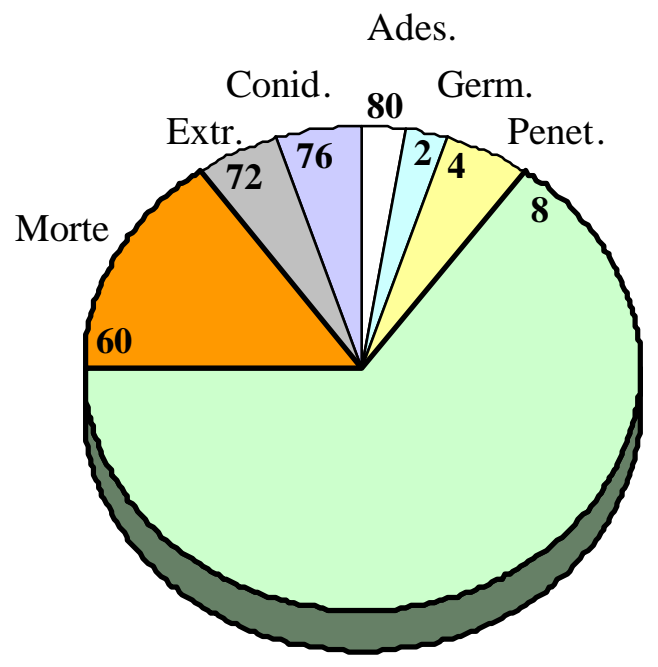

Cresc.

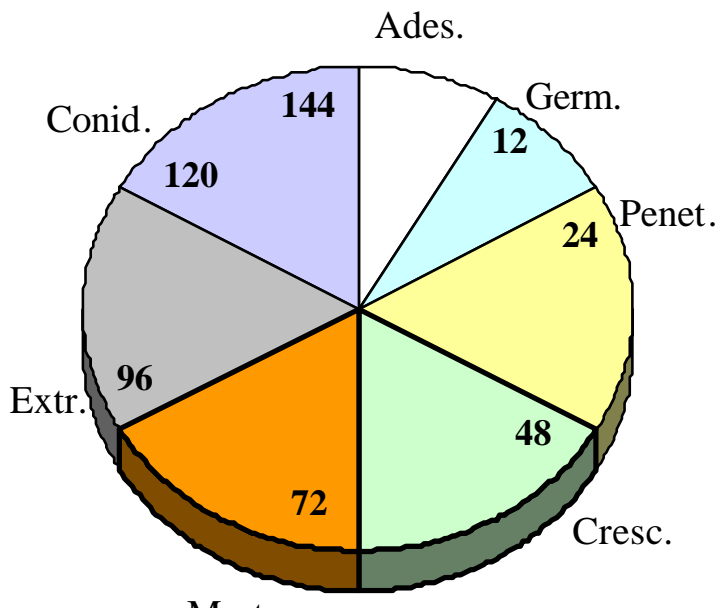

Morte

Figura 2 - Duração (horas) das fases do ciclo biológico de Neozygites floridana e Beauveria bassiana em Tetranychus urticae. Fases de adesão, germinação, penetração, crescimento vegetativo, morte do hospedeiro, extrusão do patógeno e início da conidiogênese. Fonte: Oduor et al. (1995); Oduor et al. (1996a); Oduor et al. (1996b); Oduor et al. (1997) e Neves et al. (1997)

\section{$\underline{\text { Potencial de inóculo }}$}

A fonte natural de inóculo de Entomophthorales mais importante para iniciar uma epizootia sobre população de afídeos é o solo contaminado com esporos de resistência ou outras estruturas do fungo, seguido dos adultos alados do hospedeiro infectados, e do vento transportando conídios originados de epizootias em outras áreas (Wilding, 1981).

$\mathrm{O}$ potencial de inóculo tem sido fortemente correlacionado com o desenvolvimento epizoótico de fungos Entomophthorales (Soper \& Mcleod, 1981; Carruthers et al., 1985), sendo necessário um potencial mínimo para que as epizootias se iniciem (Alves, 1986a). O desenvolvimento epizoótico de Z. radicans em população de $E$. 
kraemeri foi constatado a partir de um potencial de inóculo mínimo de 0,4 a 0,5 cadáveres do inseto com fungo por planta de feijão, em condições climáticas favoráveis (GalainiWraight et al., 1991).

\section{População do hospedeiro}

As epizootias de fungos entomopatogênicos têm sido relatadas como dependentes ou independentes da densidade populacional, mas favorecidas por este fator (Benz, 1987). A velocidade de desenvolvimento epizoótico de Entomophthora sphaerosperma foi diretamente relacionada com a densidade populacional do hospedeiro Psylla mali em pomares de maçã (Jaques \& Patterson, 1962). A densidade populacional média do curculionídeo-do-botão-floral, Choristoneura fumiferana, em regiões com presença do seu inimigo natural Z. radicans, foi de 15,1 larvas por galho da planta, enquanto que nas regiões sem a presença do patógeno foi de 11,2 larvas (Vandenberg \& Soper, 1978).

A dispersão de Entomophthorales sobre a população de um inseto pode ser dependente da densidade populacional do hospedeiro quando o potencial de inóculo do fungo encontra-se abaixo do mínimo necessário para o desenvolvimento epizoótico (Missonier et al., 1970). Glare et al. (1985) relataram que a infecção do hospedeiro via capiloconídio constitui-se em um eficiente mecanismo de transmissão do fungo sobre insetos ocorrendo em baixa densidade populacional, enquanto que as infecções originadas de conídios ejetados são mais eficientes em altas densidades populacionais.

\subsubsection{Produção}

No início dos estudos com Entomophthorales poucas tentativas de isolamento e cultivo desses patógenos obtiveram sucesso, levando os mesmos a serem caracterizados, muitas vezes, como parasitas obrigatórios (Sawyer, 1929; Wolf, 1951). O primeiro relato sobre cultivo de Entomophthorales "in vitro" foi feito por Brefeld ${ }^{8}$, citado por Wolf (1951), registrando o crescimento de Empusa muscae em carne de vitela. O fungo produziu

\footnotetext{
${ }^{8}$ BREFELD, O. Bootanische Untersuchungen über Myxomyceten und Entomophthoreen. Unters. Gesammtgeb. Mykol., v. 6, p. 35-78, 1884.
} 
micélio, corpos hifais e conidióforos, mas não conídios. Posteriormente, ocorreram diversas outras tentativas sem sucesso de cultivo dessa espécie, o que levou Speare (1912) a duvidar dessa informação. Esse autor parece ter sido o primeiro a obter o ciclo completo de Entomophthorales em meio artificial, cultivando a espécie Entomophthora pseudococci, patógeno da cochonilha da cana-de-açúcar, Pseudococcus calceolariae, no Havaí. Foram utilizados batata, batata-ágar, aveia-ágar e rabanete como meio de cultura, destacando-se os dois últimos como os melhores (Sawyer, 1929).

Sawyer (1929) realizou um dos trabalhos mais extensos sobre produção de Entomophthorales "in vitro". Avaliou o crescimento de E. sphaerosperma e Empusa sp. em 40 meios de cultura, com melhores resultados em meios a base de batata, carne de peixe e carne de porco. Diversas observações foram feitas, dentre as quais o meio líquido favorece o crescimento de micélio enquanto que o meio sólido favorece o crescimento de corpos hifais e a reprodução por conídios. Verificou-se ainda que essas espécies preferem fontes de proteínas que sejam rapidamentes hidrolizadas pelas enzimas proteolíticas secretadas pelos patógenos.

O primeiro relato sobre produção de Entomophthorales em meio de composição quimicamente definida foi feita por Wolf (1951), cultivando as espécies Entomophthora apiculata e E. coronata no meio líquido constituído de dextrose, asparagina e sais. Ambas as espécies apresentaram-se autotróficas quanto as vitaminas. E. coronata foi cultivada também no meio sintético constituido de dextrose, hidrocloreto de arginina e sais (Smith, 1953).

Müler-Kögler (1959) avaliou gema-de-ovo coagulada como meio de cultura sólido para Entomophthorales e constatou o crescimento de diversas espécies, desenvolvendo um dos meios de cultura mais populares utilizados no isolamento e cultivo desses fungos. Soper et al. (1975) utilizaram esse meio adicionado de 30\% de saboraundmaltose-agar (SDA) para a produção de Entomophthora thaxteriana na forma de esporos de resistência, desenvolvendo a primeira técnica de produção massal de Entomophthorales em meio sólido. Gröner (1975) desenvolveu a primeira técnica de produção massal em meio líquido, avaliando diferentes substratos para a obtenção de esporos de resistência desse fungo. O meio contendo glucose $(4 \%)$ mais peptona $(1 \%)$ mais extrato de levedura $(0,5 \%)$ permitiu a produção de até 500.000 esporos $/ \mathrm{mL}$. 
A glucose (fonte de carbono) e proteínas hidrolizadas (fonte basicamente de nitrogênio) são bastante convenientes para a produção de Entomophthorales (Latgé, 1975a, Latgé, 1975b; Latgé \& Remaudière, 1975; Latgé et al., 1978; Latgé, 1981). Utilizando meios líquidos constituídos de glucose e xarope de milho como fonte de carbono, e extrato de levedura, farinha de soja e farinha de semente de algodão como fontes de nitrogênio, Latgé et al. (1977) obtiveram zigósporos de Entomophthora virulenta e desenvolveram a primeira técnica de produção em larga escala de Entomophthorales usando fermentadores.

Esperando reduzir a variabilidade na produção de esporos de resistência decorrente do uso de meios contendo fontes complexas de nitrogênio, como extrato de levedura, foram realizadas algumas tentativas para desenvolver um meio quimicamente definido. Um meio constituído de dextrose, L-arginina, L-leucina, glicina e sais minerais, permitiu o crescimento e esporulação de Conidiobolus thromboides. No entanto, a produção de conídios foi significativamente maior em um meio contendo extrato de levedura (Perry \& Latgé, 1980). De acordo com Latgé \& Samglier (1985), o meio definido que proporcionou melhor conidiogênese de C. obscurus constituía-se de dextrose, 11 amino ácidos, 4 vitaminas (tiamina, biotina, ácido fólico e ácido pantotênico) e 4 sais (fosfato, sulfato de magnésio, sulfato de zinco e cloreto de manganês).

A primeira tentativa para obtenção de formas vegetativas (corpos hifais) de Entomophthorales em fermentadores foi feita por Latgé (1982) trabalhando com $E$. neoaphidis. Posteriormente, Mccabe \& Soper (1985) obtiveram sucesso desenvolvendo a primeira técnica de produção massal de micélio seco de Entomophthorales, denominada de processo "Marcescent". A produção do micélio é feita dentro de fermentadores, sendo o patógeno colhido ainda na fase ativa de crescimento, antes da exaustão de nutrientes.

Mais recentemente tem-se avaliado meios de cultura constituídos de uma fonte de açúcar e outra fonte complexa de nitrogênio, porém suplementados quase sempre de sais e aminoácidos, e algumas vezes de lipídeos e soro de feto bovino. O meio para cultura de tecido de insetos Grace's foi inicialmente utilizado para isolamento de espécies de Entomophthora spp., possibilitando, recentemente, o cultivo de espécies consideradas anteriormente obrigatórias como Neozygites parvispora, patogênico ao Thrips tabaci (Grundschober et al., 1998) e N. floridana, patógeno de T. urticae (Leite et al., 2000). 


\subsubsection{Formulação}

A formulação de Entomophthorales tem sido a etapa mais difícil para o desenvolvimento desses agentes como biopesticidas, o que tem acarretado em um pequeno número de trabalhos sobre esse assunto. Inicialmente, foram desenvolvidas metodologias para a formulação de esporos de resistência na fase de pré-esporo ou esporo, antes ou após a quebra de dormência, misturando essas estruturas com argila, diluentes, e agentes molhantes e dispersantes (Latgé, 1982).

Posteriormente, Mccabe \& Soper (1985) desenvolveram uma técnica de produção de micélio seco de Entomophthorales, a qual tem sido utilizada com sucesso também para hifomicetos (Rombach et al., 1986; Goettel et al., 1989; Pereira \& Roberts, 1990; Krueger et al., 1992). Uma solução de maltose (10\%), pulverizada sobre o micélio fresco, fornece proteção ao fungo durante o processo de secagem. Outros protetores também têm sido avaliados com sucesso para diferentes fungos entomopatogênicos, como: atapulgita, argilas montimorilonitas (Silvie, 1983), alginato (Knudsen et al., 1990; Pereira \& Roberts, 1990; Shah et al., 1998), amido pré-gelatinado (Pereira \& Roberts, 1991), polietileno glicol 8000 (Knudsen et al., 1991) e açúcares como sacarose e glucose (Roberts et al., 1987; Goettel et al., 1989; Pereira \& Roberts, 1990).

Micélio seco de $Z$. radicans tratado com maltose e armazenado a $4^{\circ} \mathrm{C}$ manteve boa viabilidade por um máximo de 80 dias em um estudo (Pell et al., 1993) e apenas 7 dias em outro (Pell et al., 1998). A preservação foi ainda pior quando o micélio seco foi quebrado em pequenos grânulos ou acondicionado a $-20^{\circ} \mathrm{C}$ após a secagem do fungo. $\mathrm{O}$ processo de granulação rompe as células, reduz a muscilagem secretada e provavelmente afeta a sobrevivência das células adjacentes intactas. $O$ fungo danificado por esse processo e pelo congelamento pode liberar enzimas hidrolíticas as quais atacam as células adjacentes (Li et al., 1993).

Segundo Li et al. (1993), fungos Entomophthorales possuem uma proteção natural contra a dessecação, proporcionada por uma muscilagem viscosa secretada sobre os conidióforos durante a formação dos mesmos. Essa muscilagem atua também como meio higroscópico que ajuda a manter a pressão de turgor das hifas em crescimento ou como lubrificante das mesmas. Pode atuar ainda como tampão fisiológico e como meio para difundir os nutrientes entre as células. Apesar desses avanços na formulação de 
Entomophthorales, os resultados de preservação desses patógenos como micélio seco são pouco satisfatórios.

\subsubsection{Utilização de Entomophthorales}

Os fungos Entomophthorales foram, inicialmente, recomendados para o controle de pragas mediante a introdução do fungo obtido em um campo com ocorrência epizoótica, para outro infestado com a praga. Dustan (1923) sugeriu três diferentes métodos de introdução:

1 - distribuição de cadáveres do hospedeiro mortos pelo patógeno;

2 - liberação do hospedeiro vivo, porém infectado;

3 - transferência de reservatórios de esporos de resistência.

Dustan (1924) recomendou, no controle da cigarrinha européia da maçã, Psyllia mali, a distribuição de 200 a 300 cadáveres com Z. radicans por pomar atacado. A técnica de distribuição de cadáveres foi utilizada com sucesso para a introdução de $N$. fresenii e Erynia neoaphidis em populações de afídeos (Dedryver, 1979; Wilding, 1981), e para a realização de programa de controle biológico clássico com Entomophthorales, pela introdução de um isolado israelence de Z. radicans em populações de Therioaphis trifolii f. maculata na Austrália (Milner et al., 1982). Essa técnica foi recomendada ainda recentemente para a utilização de Batkoa sp. visando o controle de $M$. fimbriolata em pastagens e cana-de-açúcar (Alves, 1986b; Alves, 1997).

A tranferência de solo e casca de árvore contendo esporos de resistência foi avaliada com sucesso por Hajek \& Roberts (1991) para a introdução de E. maimaiga na população da mariposa-cigana, L. díspar.

Com os avanços nos estudos sobre cultivo "in vitro" de Entomophthorales a partir de 1970, estes patógenos passaram a ser avaliados de forma mais semelhante aos inseticidas. Assim, Latgé \& Perry (1980) propuseram o uso de Entomophthorales em pulverização de esporos de resistência obtidos de meios artificiais por processo de fermentação. Todas as tentativas de uso de Entomophthorales nessa forma fracassaram (Wilding, 1982), exceto o teste realizado por Hajek et al. (1996), utilizando esporos de resistência de E. maimaiga obtidos de produção "in vivo" para o controle da mariposa- 
cigana. A aplicação do fungo foi feita na base das árvores de carvalho, em parcelas de 0,01 ha cada, utilizando-se $6 \times 10^{5}$ esporos /planta.

Considerando-se que a eficiência desses propágulos para o controle de pragas, geralmente, depende da quebra de dormência dos mesmos (Latgé, 1982), tem-se avaliado o uso desses patógenos também por outras formas. Os fungos Entomophthorales produzidos em meio sólido já foram avaliados pela exposição da colônia juntamente com o substrato sobre as plantas infestadas, ou pela distribuição de um homogeneizado do fungo mais meio (Milner et al., 1982; Wilding et al., 1986; Mcguire et al., 1987b). A distribuição de cadáveres tem apresentado melhores resultados para afídeos. Nesse caso, o fungo dissemina-se lentamente, não evitando que a praga provoque danos econômicos.

O micélio seco é uma das formas promissoras e pouco avaliada de Entomophthorales para uso no controle de pragas. Soper (1985) preconizou o uso de micélio seco do fungo $Z$. radicans para o controle do curculionídeo Choristoneura fumiferana Clemens em cultura de alfafa. Wraight \& Roberts (1987) obtiveram sucesso no controle de E. fabae em alfafa após a aplicação de $60 \mathrm{~g}$ de micélio seco de Z. radicans. Leite et al. (1993) conseguiram a formação de focos primários e indução de epizootia de $Z$. radicans em população de Empoasca sp. em cultura de feijão após aplicação de micélio seco do fungo na dosagem de $1 \mathrm{~g} / \mathrm{m}^{2}$, em pontos de $4 \mathrm{~m}^{2}$ cada.

Atualmente há vários programas referentes ao uso de Entomophthorales para o controle de pragas, sendo os principais listados na Tabela 8 . 
Tabela 8. Programas de controle de pragas com Entomophthorales.

\begin{tabular}{llcll}
\hline Fungo & Hospedeiro & Estratégia & País & Estágio \\
\hline Entomophaga maimaiga & Lymantria dispar & I. I. & EUA & $* *$ \\
E. grylli & Gafanhotos & C. B. C. & EUA & $*$ \\
Entomophthora muscae & Musca domestica & I. I. & EUA & $*$ \\
Neozygites fresenii & Aphis gossypii & C. & EUA & $* *$ \\
$N$. floridana & Mononychellus tanajoa & C. B. C. & África & $* *$ \\
Zoophthora phytonomi & Hypera posticata & C. & EUA & $* * *$ \\
Z. radicans & Empoasca spp. & I. I. & EUA e BR & $*$ \\
Z. radicans & Plutella xylostella & I. I. & EUA & $* *$ \\
Z. radicans & Therioaphis maculata & C. B. C. & AU & $* * * *$ \\
Conidiobolus spp. & Afídeos & I. I. & EUA e EU & $*$ \\
\hline
\end{tabular}

I.I. = introdução inoculativa; C.B.C. $=$ controle biológico clássico; C. = conservação.

*desenvolvimento inicial, ** desenvolvimento avançado, *** desenvolvido, **** estabelecido

Fontes: Pell \& Wilding (1994); Hajek et al. (1996); Geden et al. (1993); Giles \& Obrycki (1997); Steinkraus et al. (1995); Milner et al. (1982); Carruthers et al. (1997); Wraight \& Roberts (1987); Wilding (1982) e Moraes \& Delalibera (1992).

\subsubsection{Seletividade}

A maioria dos fungos Entomophthorales são organismos específicos ao hospedeiro e portanto seletivos a inimigos naturais e inócuos a saúde humana. Z. radicans não afetou o desenvolvimento do parasitóide Trioxys complanatus quando os inimigos naturais iniciaram a atuação simultaneamente sobre o hospedeiro $T$. trifolii $f$. maculata (Milner et al., 1984). P. neoaphidis não afetou o desenvolvimento de Metopolophium dirhodum sobre o afídeo Macrosiphum (Sitobion) avenae somente quando sua inoculação no hospedeiro foi feita quatro dias após a exposição do parasitóide (Powell et al., 1986). Altas concentrações de Z. radicans não afetaram os predadores Coleomegilla sp. e Eriopis sp., os quais estão associados a cultura do feijão (Magalhães et al., 1988). Segundo Vandenberg (1990) o fungo E. maimaiga, patógeno da marioposa cigana, L. dispar, não coloniza a abelha Apis mellifera. 
Os fungos E. neoaphidis e Conidiobolus major, patógenos das cigarrinhas Mahanarva posticata e Prosapia simulans, apresentaram-se inócuos para ratos e porcos (Toriello et al., 1986), pois foram inoculados via intraperitoneal e subcutânea em um total de 274 animais e não causaram nenhuma alteração patológica de importância. 


\section{OCORRÊNCIA NATURAL DE ENTOMOPHTHORALES EM POPULAÇÕES DAS CIGARRINHAS DAS PASTAGENS}

\section{Resumo}

As cigarrinhas das pastagens (Hemiptera: Cercopidae) estão entre as principais pragas da cultura. Devido à localização das ninfas no solo, inseticidas químicos não são eficientes no controle da praga. Embora os fungos da Ordem Entomophthorales causem epizootias ocasionais em populações das cigarrinhas das pastagens e cana-de-açúcar, tais patógenos não têm sido estudados para o controle desses insetos. Esse trabalho objetivou avaliar a ocorrência de fungos Entomophthorales na população das cigarrinhas das pastagens no município de Pindamonhangaba, SP. O experimento foi realizado em duas áreas de pastagens próximas, com 10 ha cada. As avaliações foram realizadas a cada 4 dias, entre janeiro e fevereiro de 1998, sendo feitas com a captura de insetos adultos e transporte dos mesmos para o laboratório. Para avaliar a infecção, os conteúdos do abdome e tórax dos insetos foram retirados e observado em microscópio óptico a presença de hifas ou esporos de resistência do patógeno. Nesse estudo também foram fotografados conidióforos e conídios de cada fungo utilizando microscopia eletrônica de varredura. Furia sp. foi encontrado em níveis epizoóticos atacando Deois schach na pastagem de Brachiaria, provocando até $80 \%$ de infecção com consequente queda na população do inseto. Batkoa sp. foi encontrado em nível enzoótico (< $10 \%$ de infecção) atacando Mahanarva fimbriolata na pastagem de napier (Pennisetum purpureum). Furia sp. foi também encontrado atacando outra importante cigarrinha, Deois flavopicta, indicando ser um bom agente para ser avaliado como bioinseticida. Chuva intensa pode ser um fator adversso para a ocorrência de Batkoa sp. na população de $M$. fimbriolata na pastagem de napier. 


\section{Summary}

\section{Natural occurrence of Entomophthorales on spittlebugs pests of pasture in eastern} São Paulo State, Brazil

Spittlebugs are the most important pests of pasture in Brazil. Nymph behavior, i.e. residing in the soil, makes their control with insecticides difficult. Although Entomophthorales occasionally have been found at epizootic levels in pasture spittlebug populations, these fungi have not been cultured, their incidence levels determined, nor have they been evaluated for pest control potential. The research reported here aimed at evaluating the occurrence of Entomophthorales species on spittlebug pests of pasture in Pindamonhangaba County, São Paulo State, Brazil. Evaluations were carried out in 2 adjacent fields with Brachiaria decumbens and Pennisetum purpureum grasses, respectively, and a total area of 10 ha. Evaluations were done each 4 days during January and February by capturing spittlebug adults on leaves with a $30 \mathrm{~cm}$ diameter entomological net. Insect abdomens were dissected and observed by microscopy for the presence of hyphae and resting spores. Scanning electron microscopy pictures were taken of conidiophores, and primary and secondary conidia of both fungi. Furia sp. was found at epizootic levels on Deois schach in the Brachiaria pasture, reaching $80 \%$ infected followed by a crash in the insect population. Batkoa sp. was found at enzootic levels $(<10 \%$ infected) on Mahanarva fimbriolata in the P. purpureum pasture. Furia sp. was found to infect another important spittlebug, Deois flavopicta, indicating it to be a good agent for investigation as a bioinsecticide. Heavy rainfall can be an adverse factor for occurrence of Batkoa sp. in M. fimbriolata populations on Napier pasture. 


\subsection{Introdução}

As cigarrinhas das pastagens (Hemiptera: Cercopidae) estão entre as principais pragas da cultura, causando perdas de 10 a 100\% na produção. Esses insetos sugam a seiva das plantas e injetam toxinas, levando ao aparecimento do sintoma de "queima" das pastagens (Alves, 1985). As espécies de cigarrinhas mais importantes são Deois flavopicta (Stal, 1854), Deois schach (Fabr., 1787), Zulia entreriana (Berg, 1879) e Mahanarva fimbriolata (Fabr., 1787). Esta última espécie é a principal praga do capim napier (Pennisetum purpureum Schumach) no leste do Estado de São Paulo, sendo ainda o cercopídeo praga de maior importância na cultura da cana-de-açúcar em todo o Estado.

Devido à localização das ninfas no solo, inseticidas químicos não são eficientes no controle da praga. Desta maneira, os pecuaristas buscam métodos alternativos de controle para possibilitar uma melhor convivência com a praga e reduzir o impacto ambiental, evitando problemas de intoxicação do homem e animais. O controle com o fungo Metarhizium anisopliae, uma das alternativas mais utilizadas, tem apresentado resultados bastante dependentes do tipo de cultura e condições climáticas (Ramiro \& Cottas, 1979; Cottas \& Ramiro, 1981b; Alves, 1986; Alves \& Lecuona, 1996).

Embora os fungos da Ordem Entomophthorales causem epizootias ocasionais em populações das cigarrinhas das pastagens e cana-de-açúcar (Lepage \& Monte, 1942; Guagliumi, 1969; Guagliumi, 1972; Valério \& Koller, 1982; Batista Filho, 1997; Alves, 1998), tais patógenos não têm sido estudados para o controle desses insetos. Assim, é importante conhecer as espécies de Entomophthorales que ocorrem na população desses insetos, o potencial epizoótico das mesmas, além dos fatores bióticos e abióticos que podem afetar a ocorrência desses fungos.

Essa pesquisa teve por objetivo avaliar a incidência de espécies de Entomophthorales em populações de cigarrinhas em duas espécies de gramíneas forrageiras no município de Pindamonhangaba, São Paulo.

\subsection{Material e Métodos}

O experimento foi realizado em duas áreas de pastagens próximas, com 10 ha cada, no Município de Pindamonhangaba, SP. Um campo era formado com capim napier de 
altura média de 1,0 m, enquanto que no outro, o cultivo era de capim Brachiaria decumbens com altura média de $0,5 \mathrm{~m}$.

As avaliações foram realizadas a cada 4 dias, entre janeiro e fevereiro de 1998, sendo feitas com a captura de insetos adultos e transporte dos mesmos para o laboratório. A coleta foi realizada com rede entomológica, com 50 redadas por repetição, totalizando 4 repetições para cada avaliação. Os insetos coletados foram armazenados em sacos plásticos, levados ao laboratório e colocados em freezer visando à preservação das características do hospedeiro e do patógeno até que fosse possível realizar a identificação e diagnóstico dos indivíduos infectados. Devido a predominância de $M$. fimbriolata na pastagem de napier, e D. schach no campo de braquiária, considerou-se apenas esses insetos coletados nos respectivos campos.

Para avaliar a infecção, os conteúdos do abdome e tórax dos insetos foram retirados, colocados sobre lâmina com uma gota de água e, em seguida, cobertos com uma lamínula. O material foi esmagado com a pressão da lamínula e observado em microscópio óptico a presença de hifas ou esporos de resistência do patógeno. Com base nos resultados foi calculada a porcentagem de incidência de fungos Entomophthorales nessas áreas e estimado o potencial de inóculo resultante dos níveis de infecção. Para isso foi considerado a área média coberta em cada redada, de aproximadamente $0,3 \mathrm{~m}^{2}(0,3 \mathrm{~m}$ do diâmetro arco da rede de varredura vezes o comprimento médio de $1 \mathrm{~m}$ da área coberta em cada redada), a densidade populacional do inseto e a porcentagem dessa densidade que iria morrer pelo agente. Alguns cadáveres desses insetos com os fungos foram coletados e levados ao laboratório com o bjetivo de isolar os patógenos a partir dos seus conídios utilizando meio de cultura sólido a base de extrato de levedura (2\%) e dextrose (2\%). Alguns exemplares foram também enviados ao Dr. Richard Rumber, pesquisador do USDA junto a Universidade de Cornell, Ithaca, NY, para a identificação dos gêneros

Dados de temperatura e umidade relativa foram registrados de uma estação meteorolológica localizada a $4 \mathrm{~km}$ do local do experimento. Para determinar o grau de correlação das doenças com as populações dos hospedeiros e os fatores abióticos (clima), foi aplicado o método de Pearson e regressão multipla. Considerando-se que os níveis de infecção obtidos nos diferentes levantamentos foram depedentes dos fatores climáticos nos últimos 3 a 4 dias, foram utilizadas as médias de temperatura, umidade e precipitação referentes aos dados registrados dentro desses períodos anteriores às avaliações. 
Nesse estudo também foram fotografados conidióforos e conídios dos fungo utilizando microscopia eletrônica de varredura. Para isso os fungos foram produzidos em meios sólidos constituídos de extrato de levedura (2\%), dextrose $(2 \%)$ e ágar $(1,5 \%)$, dentro de placas de Petri descartáveis de $4 \mathrm{~cm}$ de diâmetro. Após o crescimento das colônias tomando mais de $50 \%$ da área do substrato, o micélio na superfície foi cortado com bisturi em quadrados de $0,3 \times 0,3 \mathrm{~cm}$. Os pedaços obtidos do fungo foram separados do meio, transferidos para outras placas de Petri contendo ágar-água e incubados a $23^{\circ} \mathrm{C}$ durante pelo menos 12 horas para se obter conidiogênese dos fungos. Em seguida, foram retirados juntamente com o ágar-agua cortando-se o substrato ao redor do patógeno a uma distância aproximada de $0,5 \mathrm{~cm}$ do mesmo.

As amostras foram colocadas sobre a base invertida de uma placa de Petri $(9 \mathrm{~cm}$ de diâmetro), dentro de um frasco com formato de sino contendo $16 \%$ de formaldeído mais $10 \%$ de glutaraldeido e expostas ao vapor fixativo por pelo menos 24 horas. Em seguida, as amostras foram rapidamente congeladas em nitrogênio líquido Freon 113 e submetidas ao processo de liofilização por 24 horas. As amostras secas foram montadas nas bases de alumínio e expostas ao bombardeamento de ouro-paladium durante 20 segundos. Finalmente, foram visualizadas em um microscópio eletrônico de varredura Hitachi S-4000.

\subsection{Resultados e Discussão}

Constatou-se nesse estudo a ocorrência de Batkoa sp. atacando M. fimbriolata, e Furia sp. atacando D. Schach.

Aspectos taxonômicos - Batkoa sp. e Furia sp. apresentam muitas diferenças taxonômicas, algumas das quais contribuem para diferençiar o potencial epizoótico das duas espécies. O fungo Batkoa sp. possui conidióforos individualizados, com conídios primários e secundários arredondados (Figura 3). Apresenta rizóides relativamente espessos, com terminal discóide que se fixa no substrato. Verificou-se a formação de esporos de resistência em alguns hospedeiros e sobre meio de cultura sólido contendo $1 \%$ de extrato de levedura mais $2 \%$ de dextrose. Batkoa sp. aproxima-se do gênero Entomophaga, diferenciando-se principalmente pela formação de rizóides, os quais não são formados em Entomophoga (Humber, 1989). 


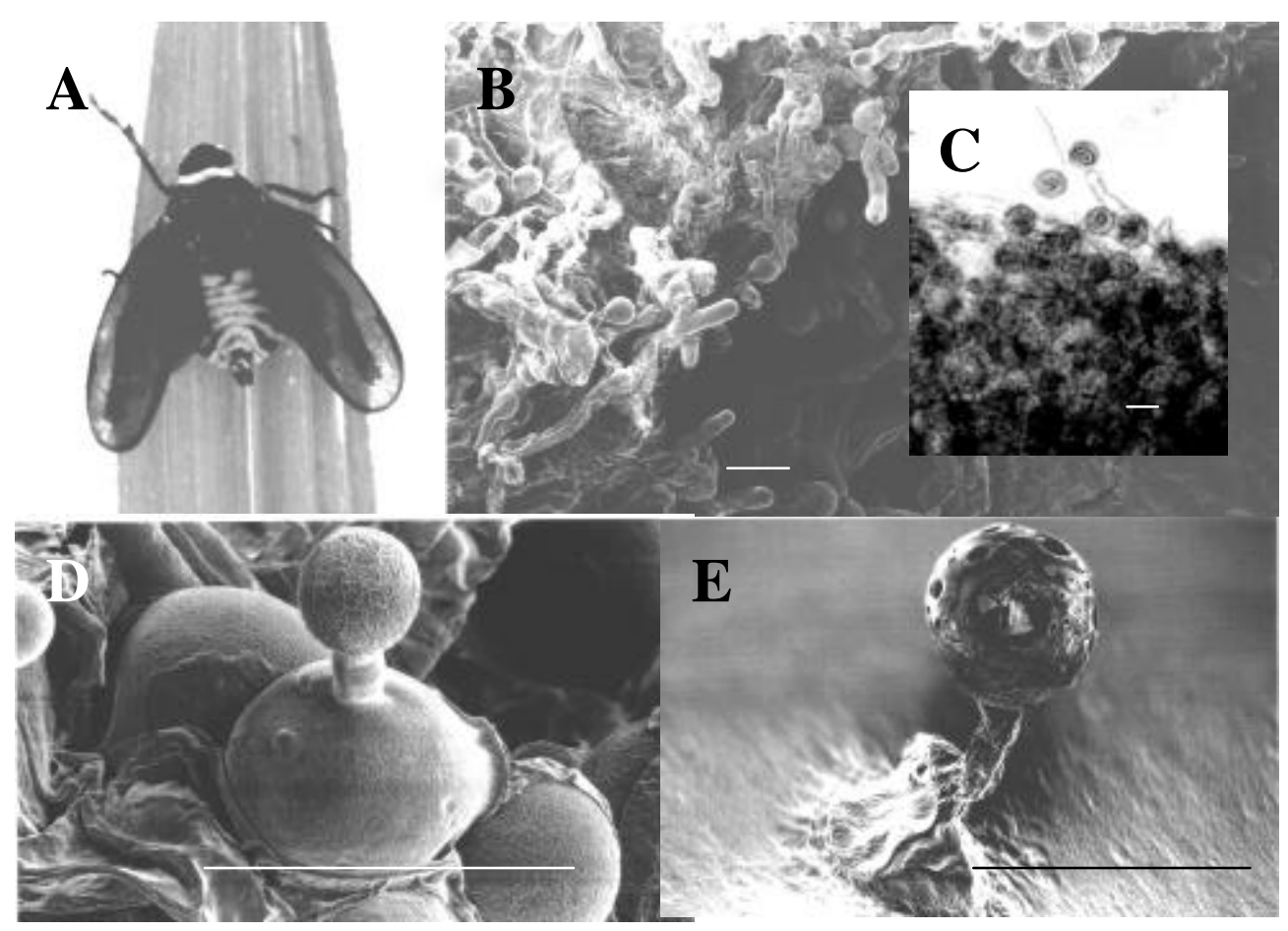

Figura 3 - Mahanarva fimbriolata (A) com Batkoa sp. Conidiogênese (B), esporos de resistência $(\mathrm{C})$ e conídios secundários $(\mathrm{D}$ e E) do fungo. Barra $=30 \mu \mathrm{m}$.

O fungo Furia sp. possui conidióforos ramificados, com conídios primários e secundários ovalados (Figura 4). Forma rizóides em grande quantidade, fasciculados ou não, sem apresentarem terminal discóide. Furia sp. aproxima-se do gênero Erynia sp., diferenciando principalmente pela formação abundante de rizóides (Humber, 1989).

A metodologia para observação dos fungos em microscopia eletrônica foi eficiente na fixação dos mesmos, evitando a destruição, de estruturas fracas como os conidióforos que formam e sustentam os conídios secundários, durante a emissão de elétrons. É uma metodologia relativamente mais fácil, segura e barata comparada às outras tradicionalmente utilizadas (Bozzola \& Russell, 1992). É mais fácil e segura por dispensar a utilização de soluções de etanol e da substância altalmente tóxica tetróxido de ósmio, bastando deixá-los encubados dentro de um frasco fechado e expostos ao vapor de formaldeído e glutaraldeído durante 24 horas. É uma técnica mais econômica pois dispensa equipamentos sofisticados de secagem do material, como aqueles utilizados para atingir o ponto crítico de secagem. Nessa metodologia foi utilizado apenas um liofilizador, o qual é mais freqüentemente encontrado em laboratórios de pesquisa. 


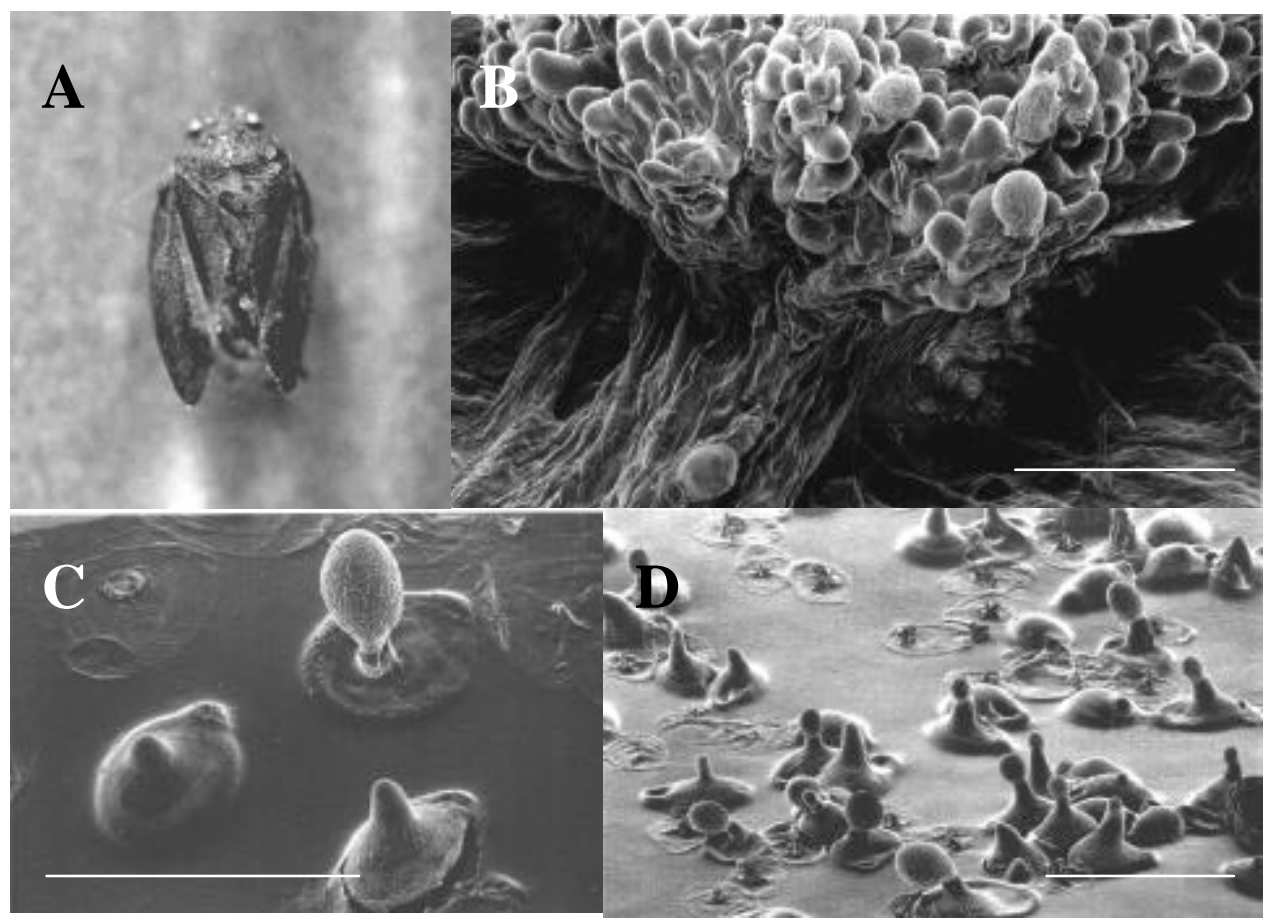

Figura 4 - Deois schach (A) com Furia sp. Conidiogênese (B) e conídios secundários (C e D) do fungo. Barra $=37,5 \mu \mathrm{m}$.

Ocorrência de Batkoa sp. - Esse fungo ocorreu em níveis enzoóticos na população de $M$. fimbriolata, não ultrapassando $8 \%$ de infecção em quase todas as avaliações (Figura 5). O nível de 100\% verificado na última avaliação não representa a incidência do patógeno, uma vêz que a população do inseto nesse período estava baixa e não foi possível a coleta de um número suficiente de indivíduos para ser analisado (4 insetos). Em geral, houve uma correlação inversa e significativa (correlação de Pearson) entre o nível de infecção e população do inseto, sugerindo que o patógeno, embora ocorrendo em baixos níveis, foi responsável pela queda da população da praga (Tabela 9). A precipitação atuou como um fator negativo sobre a infecção, já que a correlacão entre esses parâmetros foi inversa (correlação de Pearson), embora não significativa. 
Tabela 9. Estimativas dos parâmetros de regressão múltipla e coeficientes de correlação de Pearson (r) entre o desenvolvimento da doença (nível de infecção) de Batkoa sp., e a população de seu hospedeiro, Mahanarva fimbriolata, e os dados climáticos.

\begin{tabular}{lccccc}
\hline Parâmetros & \multicolumn{3}{c}{ Regreção múltipla* } & \multicolumn{2}{c}{ Correlação de Pearson } \\
\cline { 2 - 6 } & Estimativa & Erro Padrão & $\mathrm{P}^{* *}$ & $\mathrm{r}$ & $\mathrm{P}^{* *}$ \\
\hline Constante & 1,327 & 1,700 & 0,578 & - & - \\
População & $-0,990$ & 0,038 & 0,024 & $-0,991$ & 0,000 \\
Precipitação & 0,004 & 0,001 & 0,187 & $-0,199$ & 0,353 \\
Temperatura & 0,051 & 0,044 & 0,455 & $-0,459$ & 0,180 \\
Umidade & $-0,021$ & 0,010 & 0,275 & 0,131 & 0,348 \\
\hline
\end{tabular}

*Coeficiente de determinação $\left(\mathrm{r}^{2}\right)=0,999$

** $\mathrm{P}=$ valor $\mathrm{P}$ associado ao teste de significância dos parâmetros.

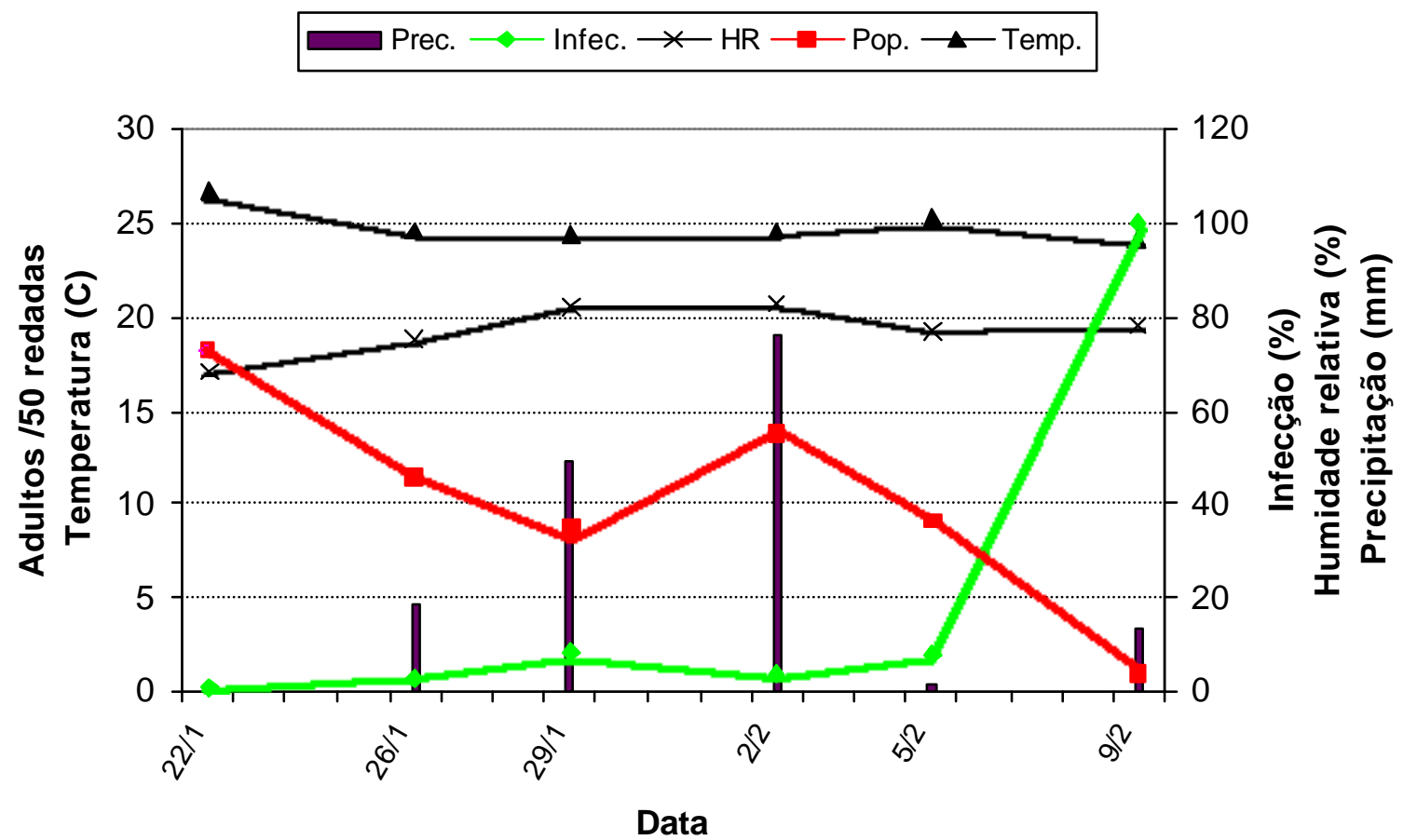

Figura 5 - Incidência de Batkoa sp. na população de Mahanarva fimbriolata em pastagem de napier, correlacionada com os parâmetros meteorológicos.. Pindamonhangaba, SP, 1999. 
A baixa incidência de Batkoa sp. ocorreu provavelmente devido ao baixo potencial de inóculo do patógeno no início das avaliações associado à umidade relativa média abaixo de $80 \%$ em grande parte das avaliações e, especialmente, aos elevados índices pluviométricos ao longo do experimento.

No primeiro levantamento foram encontrados poucos insetos infectados com o patógeno $(1,4 \%)$, o que resultou em um baixo potencial de inóculo no campo, estimado em pelo menos 1 cadáver para cada $60 \mathrm{~m}$. Para o fungo Zoophthora radicans, agente de controle da cigarrinha-verde-do-feijão, o potencial de inóculo mínimo para permitir o desenvolvimento epizoótico é de 0,4 a 0,5 cadáveres /planta de feijão (Galaini-Wraight et al., 1991).

Diversos fatores podem explicar o baixo potencial de inóculo do fungo Batkoa sp. no início dos levantamentos. Um desses fatores está relacionado à cultura de Napier, a qual é renovada ou substituída com maior frequiência que outras gramíneas usadas como pastagem, o que contribui para a redução ou mesmo eliminação das fontes de inóculo. Além disso, após cada pastoreio, a cultura oferece pouca cobertura foliar no solo, principal fonte de armazenamento dos esporos de resistência, permitindo que os mesmos sejam expostos à radiação solar e temperaturas elevadas. Matéria orgânica, umidade, proteção dos raios ultravioletas e temperaturas moderadas no subsolo são fatores favoráveis para o desenvolvimento e perpetuação de agentes entomopatogênicos, sendo muito importante para a manutenção e liberação de inóculo para a formação de focos primários (Alves, 1998).

A umidade relativa (UR) média observada em grande parte dos levantamentos permaneceu abaixo de $80 \%$, sendo desfavorável para muitos fungos Entomophthorales (Carruthers \& Haynes, 1986; Lê-ru \& Iziquel, 1990; Yu et al., 1995; Oduor et al., 1996a). A umidade relativa no agroecossistema do napier é mais problemática para o fungo em relação a outras gramíneas, uma vez que essa cultura oferece menor cobertura foliar no solo, a qual contribui para manter maior umidade no ambiente ao redor dos insetos e, consequentemente, para permitir o desenvolvimento da doença.

A chuva é um fator favorável ao patógeno desde que ocorra em baixa intensidade. Chuvas intensas como as que ocorreram ao longo do experimento, de até 67 $\mathrm{mm}$, podem ser prejudiciais por lavar os insetos contaminados com o fungo. Além disso, podem desprender e arrastar para o solo os cadáveres (esporulados) fixados nas folhas pelos 
rizóides, reduzindo o potencial de inóculo. Esse efeito adverso é enfatizado para Batkoa sp. pela correlação negativa (correlação de Pearson) entre precipitação e nível de infecção. Segundo Alves (1998), chuvas muito intensas e contínuas, durante a ocorrência dos focos primários das doenças (fase pré-epizoótica), prejudicam a disseminação do patógeno e o desenvolvimento da epizootia. Para Neozygites fumosa, o desenvolvimento epizoótico do patógeno em população de Phenacoccus manihot esteve mais relacionado a frequiência de chuva do que a precipitação total (Lê-ru \& Iziquel, 1990).

A baixa incidência do patógeno permitiu que a população de $M$. fimbriolata se mantivesse alta, acima de 8 exemplares por 50 redadas, na maior parte do período avaliado. A redução da população nas duas últimas avaliações deveu-se, provavelmente, ao término do ciclo do inseto.

Ocorrência de Furia sp. - Esse fungo ocorreu em níveis epizoóticos na população de D. schach, causando até $80 \%$ de infecção (Figura 6). A precipitação e umidade relativa foram os fatores climáticos mais importantes para o desenvolvimento da doença, apresentando uma correlação direta significativa (correlação de Pearson) com a ocorrência do patógeno (Tabela 10). 
Tabela 10. Estimativas dos parâmetros de regressão múltipla e coeficientes de correlação de Pearson (r) entre o desenvolvimento da doença (nível de infecção) de Furia sp. e a população de seu hospedeiro, Deois schach, e os dados climáticos.

\begin{tabular}{lccccc}
\hline \multirow{2}{*}{ Parâmetros } & \multicolumn{3}{c}{ Regreção múltipla* $^{*}$} & \multicolumn{2}{c}{ Correlação de Pearson } \\
\cline { 2 - 6 } & Estimativa & Erro Padrão & $\mathrm{P}^{* *}$ & $\mathrm{r}$ & $\mathrm{P}^{* *}$ \\
\hline Constante & $-2,06$ & 0,289 & 0,089 & - & - \\
População & 0,051 & 0,006 & 0,073 & $-0,184$ & 0,364 \\
Precipitação & 0,009 & 0,000 & 0,015 & 0,994 & 0,000 \\
Temperatura & 0,029 & 0,006 & 0,137 & $-0,525$ & 0,143 \\
Umidade & 0,020 & 0,002 & 0,062 & 0,825 & 0,022 \\
\hline
\end{tabular}

*Coeficiente de determinação $\left(r^{2}\right)=0,977$

** $\mathrm{P}=$ valor $\mathrm{P}$ associado ao teste de significância dos parâmetros.

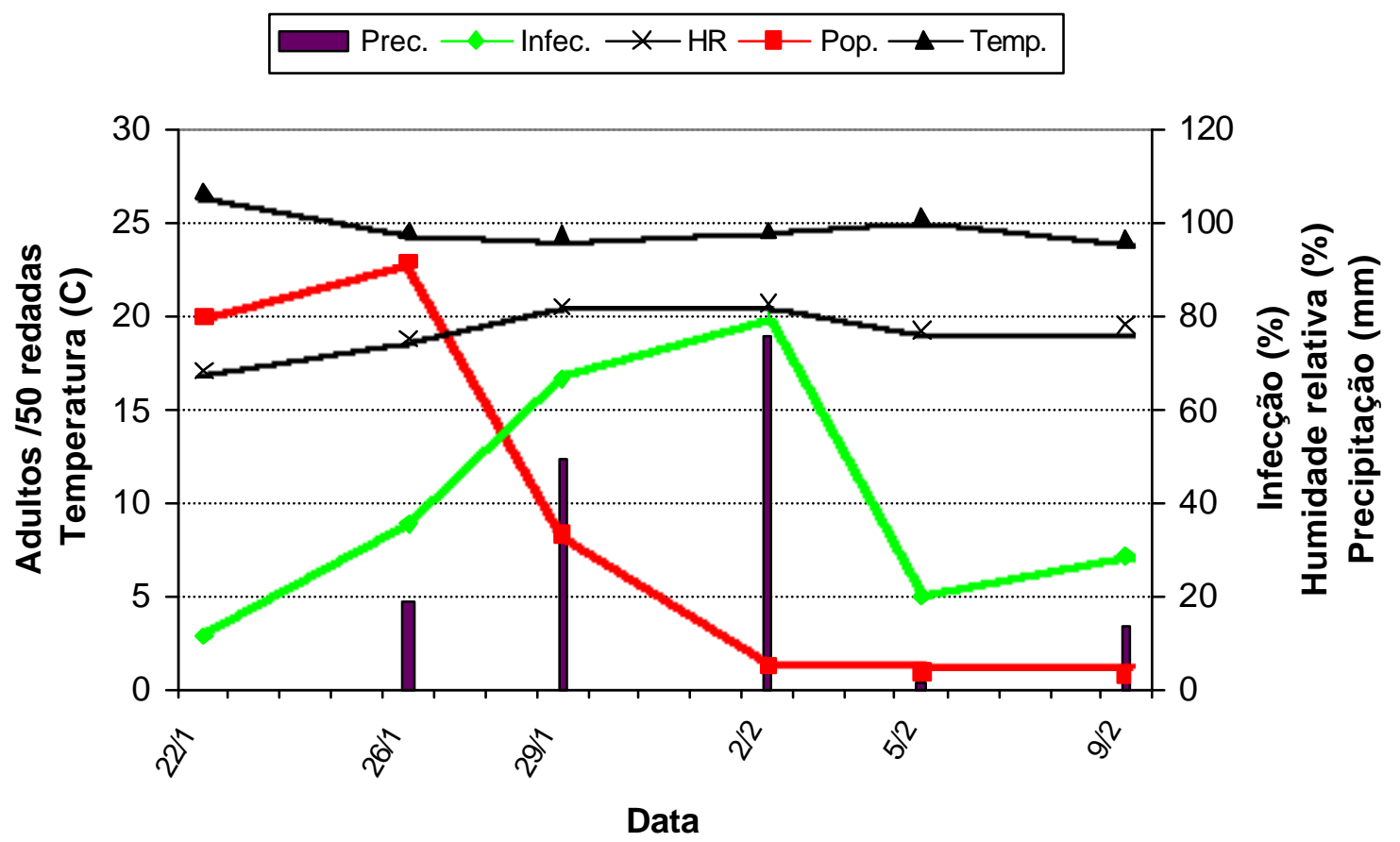

Figura 6 - Incidência de Furia sp. na população de Deois schach em pastagem de Brachiaria decumbens, correlacionada com os parâmetros meteorológicos. Pindamonhangaba, SP, 1999. 
A alta incidência de Furia sp. deveu-se, provavelmente, ao seu elevado potencial de inóculo no início das avaliações, associado ao elevado potencial epizoótico desse microrganismo e as condições favoráveis oferecidas pela cultura de B. decumbens.

No primeiro levantamento foram encontrados diversos cadáveres do inseto com o patógeno, o que contribuiu para que o nível de infecção encontrado (11,5\%) fosse relativamente elevado. O potencial de inóculo resultante desse nível de infecção pode ser estimado em pelo menos 1 cadáver para cada $6 \mathrm{~m}^{2}$, sendo portanto bem maior que aquele estimado para Batkoa sp. (1 cadáver $/ 60 \mathrm{~m} \mathrm{~m}^{2}$ ). Esse potencial de inóculo é menor do que aquele determinado para Zoophthora radicans como o mínimo necessário para permitir o seu desenvolvimento epizoótico sobre população de Empoasca sp. na cultura do feijão, de 0,4 a 0,5 cadáveres /planta (Galaini-Wraight et al., 1991). No entanto, deve-se considerar que o hospedeiro de Furia sp. é bem maior que o de Z. radicans, permitindo que o primeiro patógeno produza uma maior quantidade de conídios por cadáver.

Furia sp. é um patógeno de elevado potencial epizootico, pois cresce muito mais rapidamente em meio artificial comparado a Batkoa sp., com maior produção de conídos (Figura 4). Uma das principais características de Furia sp. é que o mesmo fixa o inseto hospedeiro no substrato vegetal utilizando uma grande quantidade de rizóides (Humber, 1997). Isso dificulta o desprendimento do cadáver e inviabilização do fungo após sua queda no solo como consequiência da chuva ou outros fatores adversos. Esse patógeno apresentou-se como um organismo estrategista r, pois ocorreu em níveis epizoóticos na população do hospedeiro. Esses organismos produzem inóculo suficiente para persistir até o retorno do hospedeiro, pois atacam insetos de ciclo relativamente curto, com alto poder reprodutivo e de disperção (Evans \& Entwistle, 1987). Batkoa sp, entretanto, apresentou-se mais como organismo estrategista $\mathrm{r}-\mathrm{k}$ ou $\mathrm{k}$, já que ocorreu em níveis enzoóticos na população do hospedeiro. Esses organismos são encontrados com maior freqüência em um mesmo habitat e atacam hospedeiro de ciclo mais longo, com menor poder reprodutivo e de disperção, geralmente associados a culturas perenes.

O campo de B. decumbens apresentava condições bastante favoráveis ao patógeno. A pastagem, mantida já há 3 anos sem rotação, contribuiu para a preservação do inóculo na área. A menor estatura dessa gramínea $(0,5 \mathrm{~m}$ em média) em relação ao napier (1,0 m em média) pemitiu que os insetos de D. schach se mantivessem mais agrupados, favorecendo a disseminação do patógeno na população da praga. Além disso, a Brachiaria 
sp. apresentava massa vegetal extremamente abundante, formando uma cobertura sobre o solo de $8 \mathrm{~cm}$ de espessura em média. Esses fatores contribuíram para que a umidade nas proximidades do solo se mantivesse mais elevada, permitindo a atuação do patógeno sobre os adultos recém emergidos e protegendo o agente contra a ação da chuva e radiação solar. Portanto, a elevada precipitação que ocorreu durante o experimento não foi prejudicial para Furia sp. e, pelo contrário, aumentou a UR no ambiente, permitindo a atuação do fungo. Isso pode ser confirmado pela correlação direta e significativa (correlação de Pearson) entre esses dois fatores climáticos e a incidência do patógeno. A precipitação média que ocorreu ao longo do experimento, de 7,6 mm, esteve próxima da faixa ótima de 3,6 a 7,0 mm para o desenvolvimento de epizootias de Zoophthora phytonomi no curculionideo Hypera posticata segundo Giles et al. (1994).

A queda no nível de infecção para $20 \%$ na penúltima avaliação deveu-se, provavelmente, a redução do potencial de inóculo e da população do inseto. Assim. Ficou evidente que o patógeno teve uma importante atuação no controle da cigarrinha (Figura 2).

Durante os levantamentos foram encontrados poucos espécimens de $D$. flavopicta. Esses insetos foram também avaliados quanto a presença de infecção, tendo sido constatado um nível de $28 \%$ (23 insetos avaliados) e 100\% (2 insetos avaliados) nas datas de $29 / 1$ e $2 / 2$.

Assim, esses resultados demonstram que o fungo Furia sp. apresenta grande potencial de uso para o controle das cigarrinhas das pastagens pertencentes as espécies $D$. schach e D. flavopicta.

\subsection{Conclusões}

Os ensaios e observações realizadas permitiram concluir que:

1. Batkoa sp. e Furia sp. causam doença na população de M. fimbriolata e D. schach, respectivamente;

2. Furia sp. possui maior potencial epizootico que Batkoa sp.. 


\section{EFEITO DE SAIS, VITAMINAS, AÇÚCARES E FONTES DE NITROGÊNIO NA PRODUÇÃO DE ENTOMOPHTHORALES}

\section{Resumo}

Fungos Entomophthorales geralmente causam episotias na população de insetos e ácaros mas, por outro lado, são difíceis de serem desenvolvidos como bioinseticidas. Meios para cultura de tecido de insetos têm permitido o crescimento de várias espécies referidas ainda recentemente como parasitas obrigatórias. Esse estudo teve por objetivo avaliar o efeito dos sais, vitaminas e aminoácidos usados no meio para cultura de tecido de insetos, Grace's suplementado, além de fontes de carbono e outras de nitrogênio, na produção em meio líquido de micélio ou corpos hifais de Batkoa sp. e Furia sp., patógenos das cigarrinhas das pastagens e cana-de-açúcar, e Neozygites floridana, patógeno de diversos ácaros. Esses fungos se assemelharam quanto ao crescimento em meios adicionados de sais, vitaminas e aminoácido, e em meio completo. A adição de sais ao meio básico proporciona um aumento significativo na produção das três espécies de fungos, e maior do que a adição de vitaminas e aminoácidos. Batkoa sp., Furia sp. e N. floridana se assemelharam quanto ao crescimento em meios contendo diferentes fontes de carbono, mas se diferenciam em meios com diferentes fontes de nitrogênio. $\mathrm{O}$ meio contendo 2,66\% de glucose proporciona uma produção das três espécies de fungos significativamente maior do que o meio com 2,66\% de sacarose. A adição de $0,1 \%$ de monossacarídeos no meio com $2,66 \%$ de sacarose não aumenta significativamente a produção dos fungos. 


\section{Summary}

\section{Effect of salts, vitamins, sugars and sources of nitrogen on the culture of three Entomophthorales species: Batkoa sp., Furia sp. and Neozygites floridana}

Entomophthorales fungi frequently cause epizootics in insect and mite populations, but most species have not been developed as biopesticides largely because of difficulty and expense of mass production. Insect cell culture media have allowed growth of several species which, until recently, were referred to as obligate pathogens. The research reported here was designed to provide simple inexpensive media for three Entomopthorales isolates: Batkoa sp. and Furia sp., pathogens of the spittlebugs pests of pasture and sugar-cane in Brazil, and Neozygites floridana, which is pathogenic to several mite species. The salts, vitamins and amino acids in insect cell culture medium (Grace's supplemented with lactalbumen hydrolysate and yeastolate) were used with different sources of carbon and nitrogen. The new media were evaluated for their effects on the production of mycelium or hyphal bodies in liquid medium. Batkoa sp., Furia sp. and N. floridana are similar concerning their growth patterns in the Grace's medium and in media with added salts, vitamins and amino acids. The addition of salts to the basic medium causes a significant increase in biomass production of the three fungal species. There was less effect from the addition of vitamins and amino acids. Batkoa sp., Furia sp. and $N$. floridana are similar concerning their growth patterns in media with different sources of carbon, but different in media with different sources of nitrogen. The production of the three fungal species is significantly higher in a medium containing $2.66 \%$ glucose than in $2.66 \%$ sucrose. The addition of $0.1 \%$ monossacarides to media containing $2.66 \%$ sucrose does not significantly increase biomass production. 


\subsection{Introdução}

Os fungos Entomophtorales patogênicos a insetos e ácaros possuem uma estreita relação com seus hospedeiros, o que permite que esses agentes causem epizootias, como tem sido observado para Batkoa sp., Furia sp., e Neozygites floridana (Weiser \& Muma) Remaudière \& Keller. Batkoa sp. e Furia sp. são patógenos das cigarrinhas Mahanarva fimbriolata (Fabr., 1787) e Deois schach (Fabr., 1787), importantes pragas das pastagens, podendo a primeira espécie atacar também cana-de-açúcar (Lepage \& Monte, 1942; Batista Filho et al., 1997; Alves, 1998). N. floridana é patogênico a diversas espécies de ácaros, incluindo o ácaro rajado, Tetranychus urticae Koch (Alvares et al. 1991), o qual pode atacar muitas culturas em diversas partes do mundo (Wolf, 1951; Latgé, 1981; Beauvais \& Latgé, 1988).

Por outro lado, essa forte relação dos fungos Entomophthorales com seus hospedeiros torna esses entomopatógenos muito mais difíceis de serem desenvolvidos como bioinseticidas. O crescimento desses agentes "in vitro" depende, geralmente, da espécie, meio de cultura e componentes usados na preparação do meio (Latgé, 1981). Meios para cultura de tecido de insetos têm permitido o crescimento de várias espécies referidas ainda recentemente como parasitas obrigatórias, como N. parvisporas, patogênico a Thrips tabaci (Grundschober et al., 1998) e N. floridana (Leite et al., 2000). No entanto, meios de cultura simples e baratos tornam-se necessários para a produção em maior escala desses patógenos, visando a utilização prática dos mesmos em programas de controle microbiano. Esse estudo teve por objetivo avaliar o efeito dos sais, vitaminas e aminoácidos usados no meio para cultura de tecido de insetos, Grace's suplementado, além de fontes de carbono e outras de nitrogênio, na produção em meio líquido de Batkoa sp., Furia sp. e N. floridana.

\subsection{Material e Métodos}

Efeito de sais , vitaminas e aminoácidos - Foram elaborados 6 tratamentos: a) meio básico [sucrose $(2,66 \%)+$ glucose $(0,07 \%)+$ frutose $(0,04 \%)+$ lactalbumina hidrolisada $(0,33 \%)$ + yeastolate $(0,33 \%)]$; b) meio básico + sais; c) meio básico + vitaminas; d) meio básico + aminoácidos; e) meio básico + sais + vitaminas + aminoácidos 
f) Grace's suplementado com lactalbumina hidrolizada mais yeastolate ( $\mathrm{HyQ}^{\circledR} \mathrm{TNM}-\mathrm{FH}$, \#SH30280.02) (testemunha).

Foram utilizados todos os sais e vitaminas, e 66,7\% (1/3) dos aminoácidos que fazem parte da composição do meio Grace's suplementado (pg.133), sendo todos os componentes com suas concentrações citados a seguir:

- Sais - $\mathrm{CaCl}_{2} \cdot 2 \mathrm{H}_{2} \mathrm{O}(0,06 \%), \mathrm{KCl}(0,28 \%), \mathrm{MgCh}_{2} \cdot 6 \mathrm{H}_{2} \mathrm{O}(0,16 \%)$, $\mathrm{MgSO}_{4} .7 \mathrm{H}_{2} \mathrm{O}(0,2 \%), \mathrm{NaHCO}_{3}(0,03 \%), \mathrm{NaH}_{2} \mathrm{PO}_{4} \cdot \mathrm{H}_{2} \mathrm{O}(0,1 \%)$;

- Vitaminas - Ácido para-aminobenzóico (0,002\%), Biotina (0,002\%), D-Pantotenato de cálcio $(0,002 \%)$, Choline (0,02\%), Ácido fólico (0,002\%), Finositol (0,002\%), Ácido nicotinico (0,002\%), Piridoxina $\mathrm{HCl}(0,002 \%)$, Riboflavina $(0,002 \%)$, Tiamina $\mathrm{HCl}(0,002 \%)$;

- Aminoácidos - L-alanina (0,0225\%), L-arginina.HCl (0,07\%), Lasparagina (0,035\%), L-ácido glutâmico (0,06\%), L-glutamina (0,06\%), L-histidina (0,25\%), L-isoleucina (0,005\%), L-leucina (0,0075\%), L-lisina.HCl (0,0625\%), Lmethionina $(0,005 \%)$, L-fenilalanina $(0,015 \%)$, L-prolina $(0,035 \%)$, L-serina $(0,055 \%)$, L-valina $(0,01 \%)$.

$\mathrm{Na}$ preparação dos meios de cultura utilizou-se a esterilização por filtragem em filtro de 0,22 $\mu \mathrm{m}$, uma vez que a esterilização por autocalvagem proporciona a precipitação dos sais. Antes de realizar a filtragem os meios iveram o $\mathrm{pH}$ ajustado para 6,2, usando-se soluções esterilizadas de $\mathrm{HCl}(0,1 \%)$ e $\mathrm{NaOH}(10 \%)$.

Para os fungos Batkoa sp. e Furia sp. foram utilizadas 6 repetições por tratamento, sendo cada repetição representada por um tubo plástico $(2,8 \times 11,8 \mathrm{~cm})$ de 50 $\mathrm{mL}$ contendo $8 \mathrm{~mL}$ do meio de cultura. O fungo utilizado para inoculação dos tubos foi obtido de uma colônia proveniente de meio de cultura sólido, constituído de extrato de levedura $(2 \%)$, dextrose $(2 \%)$ e ágar $(1,5 \%)$. Cada tubo foi inoculado com um pedaço de 0,3 x 0,3 cm do meio colonizado. Após a inoculação, os tubos foram parcialmente tampados, visando permitir a troca de gases, e acondicionados em um agitador orbital, ajustado para $200 \mathrm{rpm}$, na temperatura de $23^{\circ} \mathrm{C}$ e fotofase de 14 horas.

Após um período de 7 dias procedeu-se a avaliação quanto a produção de massa seca dos patógenos nos diferentes meios de cultura. Para isso, o fungo foi filtrado sobre papel de filtro de $45 \mathrm{~mm}$ de diâmetro utilizando-se uma bomba de vácuo, descartando-se o meio de cultura. Os papéis de filtro, antes de serem utilizados, foram mantidos por 24 horas 
a $70^{\circ} \mathrm{C}$ e, em seguida, pesados. Após a filtragem, os papéis de filtro com o fungo foram submetidos ao mesmo procedimento.

Para o fungo N. floridana foram utilizadas 5 repetições por tratamento, sendo cada repetição representada por um tubo plástico $(1,5 \times 9,5 \mathrm{~cm})$ de $8 \mathrm{~mL}$ contendo $2 \mathrm{~mL}$ do meio de cultura. Cada tubo foi inoculado com $1,2 \times 10^{5}$ corpos hifais de $N$. floridana, a partir de $0,1 \mathrm{~mL}$ de uma suspensão do fungo obtido em meio líquido Grace’s suplementado. Após a inoculação, os tubos foram tampados, agitados em vortex e acondicionados em um agitador orbital, ajustado para $200 \mathrm{rpm}$, na temperatura de $23^{\circ} \mathrm{C}$ e fotofase de 14 horas. Os tubos foram posicionados com inclinação de $45^{\circ}$ no agitador, sendo suas tampas mantidas levemente desatarraxadas.

As avaliações foram feitas a cada 4 dias, determinando-se a concentração de corpos hifais $/ \mathrm{mL}$ para cada tubo. $\mathrm{Na}$ instalação do experimento, também foram inoculados outros 5 tubos, contendo $2 \mathrm{~mL}$ de água destilada por tubo, com o objetivo de determinar a concentração inicial de corpos hifais. Os tubos foram agitados em vortex e a concentração do fungo determinada com o auxílio de uma câmara de Neubauer e um microscópio óptico com contraste de fase, utilizando-se a objetiva de $100 \mathrm{X}$.

Efeito de açúcares - Foram considerados 7 tratamentos: a) sucrose $(2,66 \%)$; b) glucose $(2,66 \%)$; c) sucrose $(2,66 \%)+$ glucose $(0,1 \%)$;) sucrose $(2,66 \%)+$ frutose $(0,1 \%) ;$ e) sucrose $(2,66 \%)+$ maltose $(0,1 \%) ;$ f) sucrose $(2,66 \%)+$ inositol $(0,1 \%) ; \mathrm{g})$ Grace's suplementado (testemunha).

Os meios contendo os diferentes açúcares foram preparados com lactalbumina hidrolisada $(0,33 \%)+$ yeastolate $(0,33 \%)$ como fontes de nitrogênio, mais os sais utilizados no estudo anterior, nas mesmas concentrações. Para os três fungos (Batkoa sp., Furia sp. e N. floridana) foram utilizadas as mesmas metodologias descritas no estudo anterior (efeito de sais, vitaminas e aminoácidos) exceto que para os fungos Batkoa sp. e Furia sp. foram consideradas 7 repetições por tratamento.

Efeito de fontes de nitrogênio - Foram considerados 13 tratamentos, representados pelas seguintes fontes de nitrogênio: a) lactalbumina hidrolisada (1\%); b) yeastolate $(1 \%)$; c) extrato de levedura $(1 \%)$; d) extrato de carne $(1 \%)$; e) peptona $(1 \%)$; f) leite desnatado (1\%); g) caseina hidrolisada (1\%); h) proteína hidrolisada de soja (1\%); i) 
caldo de soja (1\%); j) xarope de milho (1\%); k) gema de ovo (1\%); 1) lactalbumina hidrolisada $(0,33 \%)$ + yeastolate $(0,33 \%) ; \mathrm{m})$ Grace's suplementado (testemunha).

Os meios contendo as fontes de nitrogênio foram preparados com 2,66\% de glucose (dextrose) mais os sais utilizados nos estudos anteriores. Esses componentes foram esterilizados em soluções separadas, antes de serem misturados. Isso se deveu a dois motivos: - a autoclavagem do açúcar e das fontes de nitrogênico em uma mesma solução resulta em efeitos deletérios a $N$. floridana; - a autoclavagem dos sais em uma mesma solução resulta na precipitação dos minerais.

Portanto, o açúcar e as fntes de nitrogênico foram autoclavados em soluções contendo o dobro de suas concentrações para, em seguida, serem misturados em partes iguais. No preparo dos meios a base de soja e glúten de milho, os componentes "in natura" foram inicialmente deixados de molho em água destilada por 24 horas e, em seguida, autoclavados por 15 minutos. Os componentes em água foram homogeneizados em liquidificador e filtrados em papel de filtro, com o auxílio de uma bomba de vácuo. O material sólido foi descartado e o caldo extraído completado com água destilada até que o volume resultasse na porcentagem desejada dos respectivos componentes "in natura". Em seguida, o caldo foi autoclavado por 15 minutos e, então, utilizado no preparo do meio.

No preparo do meio com gema de ovo, realizou-se inicialmente a extração da gema em condições assépticas. Metade da superfície externa do ovo foi esterilizada expondo a mesma em uma chama produzida por um bico de Bunsem e, em seguida, perfurada com o auxílio de um bisturí previamente esterilizado. A partir desse orifício extraiu-se inicialmente a clara e, finalmente, a gema. A clara foi descartada e a gema misturada com água destilada estéril, utilizando-se o volume necessário para obter a concentração de $1 \%$.

Para a esterilização prévia dos sais, soluções dos minerais altamente concentradas foram filtradas em filtro de 0,22 $\mu \mathrm{m}$, com o auxílio de uma seringa. Visandose evitar a reação entre os sais nas soluções altamente concentradas, as mesmas foram preparadas com apenas dois tipos de sais (compatíveis entre si) cada uma, empregando-se a mistura de $\mathrm{CaCh} .2 \mathrm{H}_{2} \mathrm{O}$ com $\mathrm{KCl}, \mathrm{MgCh}_{2} \cdot 6 \mathrm{H}_{2} \mathrm{O}$ com $\mathrm{NaH}_{2} \mathrm{PO}_{4} \cdot \mathrm{H}_{2} \mathrm{O}$, e $\mathrm{MgSO}_{4} .7 \mathrm{H}_{2} \mathrm{O}$ com $\mathrm{NaHCO}_{3}$. A primeira mistura foi preparada na concentração de $50 \%$ para cada sal, enquanto que a segunda e terceira na concentração de $100 \%$. 
Para finalizar o preparo, os meios tiveram o $\mathrm{pH}$ ajustado para 6,2. O ajuste foi realizado utilizando soluções, também esterilizadas por filtragem, de $\mathrm{HCl}(0,1 \%)$ e $\mathrm{NaOH}$ $(10 \%)$.

Quanto ao restante da metodologia, realizaram-se os mesmos procedimentos utilizados no estudo dos efeitos de sais, vitaminas e aminoácidos, exceto para $N$. floridana, o qual foi avaliado somente uma vez quanto a produção, com 4 dias após a inoculação.

Os experimentos foram submetidos a análise de variância e as médias comparadas pelo teste de Tukey $(\mathrm{P}<0,05)$.

\subsection{Resultados e Discussão}

Efeito de sais, vitaminas e aminoácidos - As três espécies de Entomophthorales foram semelhantes quanto ao crescimento nos meios básicos adicionados de sais (SA), vitaminas (VI) e aminoácido (AA), e no meio completo (MC) (Figuras 7 e 8). O meio com sais proporcionou maior produção para as três espécies de fungo, em relação aos meios com vitaminas e aminoácidos, resultando em rendimentos significativamente maiores comparado ao meio básico (BA) para Batkoa sp. (F = 24,56; $\mathrm{P}$ $=0,000)$ e Furia sp. $(\mathrm{F}=13,43 ; \mathrm{P}=0,000)$.

Os aminoácidos representam o segundo grupo de maior importância na produção das três espécies de fungos, embora não tenham proporcionado aumento significativo para Batkoa sp. e Furia sp. Esse grupo e o dos sais apresentam grande importância para a produção de $N$. floridana, visto que o fungo não cresceu no meio sem esses componentes (BA) (Figura 8). O meio com sais proporcionou uma produção ligeiramente maior em relação ao meio com aminoácido, porém, o fungo obtido nesse último se reproduziu mais rapidamente.

Já as vitaminas não apresentaram nenhum efeito na produção das diferentes espécies de Entomophthorales. Apesar disso, não se pode concluir quanto a importância das vitaminas na produção das espécies estudadas uma vez que as mesmas poderiam estar presentes também no meio básico, na quantidade necessária para o crescimento desses patógenos, tendo sido fornecidas pelos componentes lactalbumina hidrolisada e yeastolate. 
Batkoa sp.

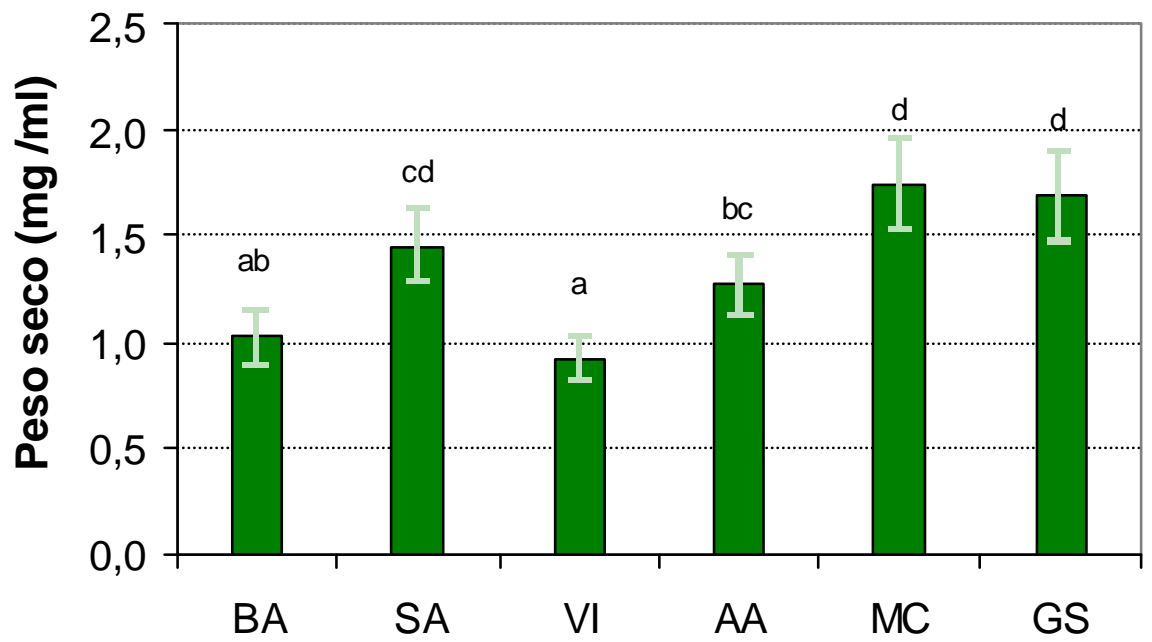

Furia sp.

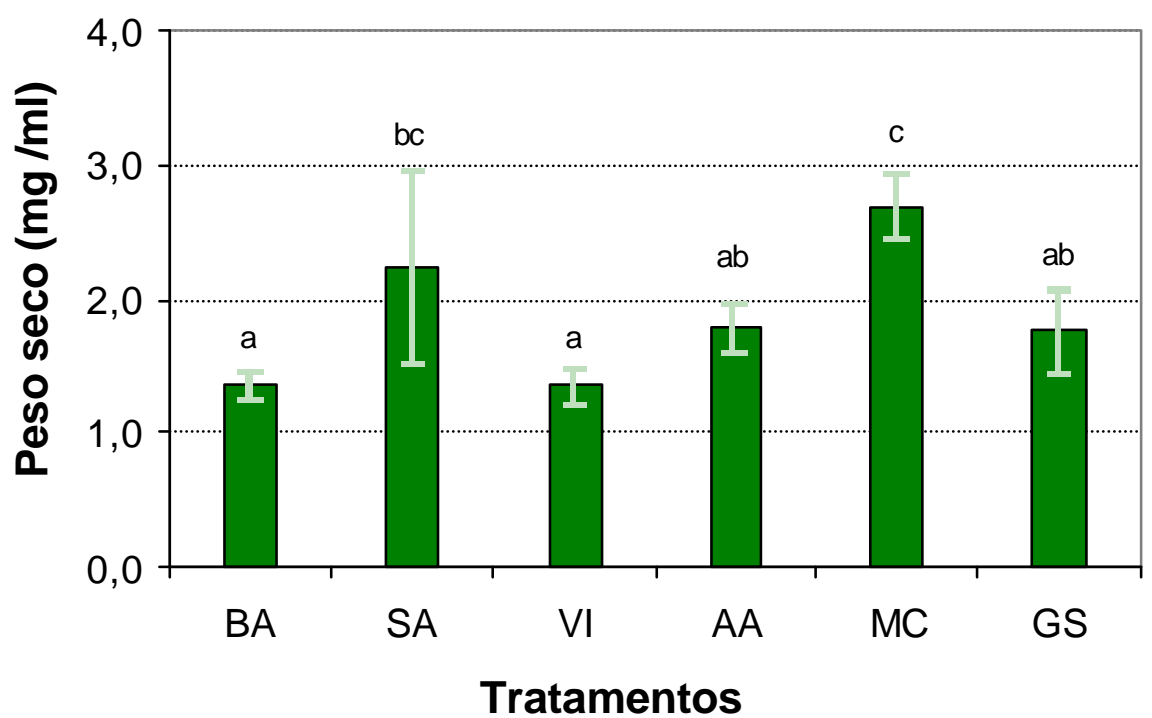

Figura 7 - Produção de biomassa dos fungos Batkoa sp. e Furia sp. em meios líquidos. BA = meio básico; $\mathrm{SA}=$ meio básico + sais; $\mathrm{VI}=$ meio básico + vitaminas; $\mathrm{AA}=$ meio básico + aminoácidos; $\mathrm{MC}=$ meio básico + os três componentes juntos; GS = meio Grace's suplementado. Tratamentos com a mesma letra não diferem entre si pelo teste de Tukey, ao nível de 5\% de probabilidade. Barras $=$ desvio padrão. 


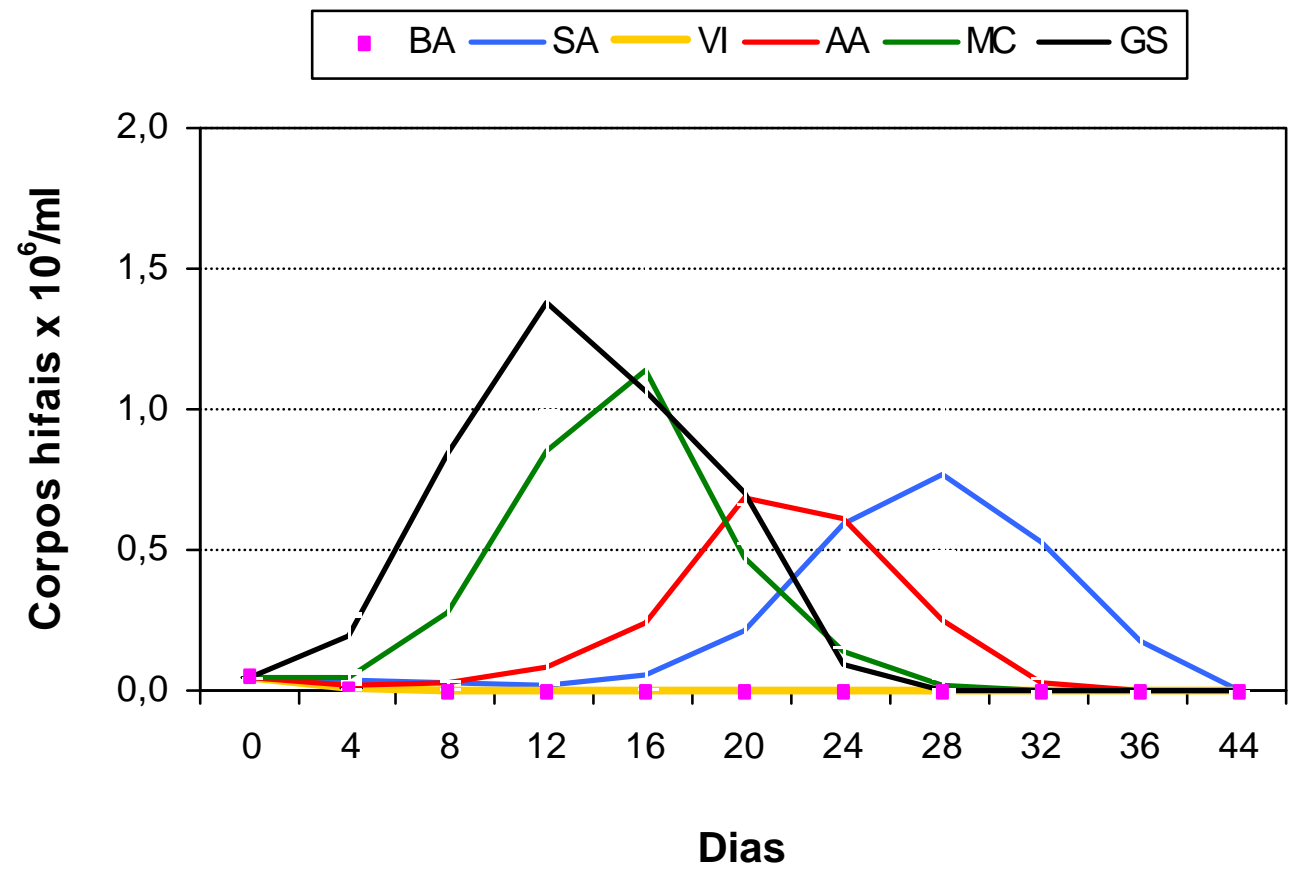

Figura 8 - Produção de Neozygites floridana em meios líquidos. BA = meio básico; SA = meio básico + sais; VI $=$ meio básico + vitaminas; $\mathrm{AA}=$ meio básico + aminoácidos; $\mathrm{MC}=$ meio básico + os três componentes juntos; $\mathrm{GS}=$ meio Grace's suplementado. Barras = desvio padrão.

O meio adicionado de sais, aminoácidos e vitaminas (meio completo) proporcionou, para as três espécies de patógenos, maior produção do que os meios contendo esses grupos isolados, não diferenciando significativamente, porém, do meio contendo sais. Para a espécie Furia sp., o meio completo proporcionou uma produção superior ao meio Grace's suplementado, com diferença significativa.

Um meio de cultura deve possuir, basicamente, uma fonte de carbono (C) e nitrogênio $(\mathrm{N})$, sais minerais e alguns fatores de crescimento (Soper \& Ward, 1981). Existem diversos estudos sobre avaliação de fontes de carbono e nitrogênio para a produção de fungos entomopatogênicos, mas poucos referem-se ao uso de sais. Entretanto, esses nutrientes inorgânicos possuem grande importância no crescimento, desenvolvimento e até mesmo sobrevivência de fungos.

O magnésio estabiliza ATP, RNA e enzimas, podendo ainda afetar as fibras do fuso cromático. $\mathrm{O}$ fósforo é um componente estrutural dos ácidos nucleicos, fosfolipídeos e 
vitaminas, atuando na forma de polifosfato como um mecanismo para a estocagem de cátions, juntamente com o magnésio e ferro. O potássio, devido a sua passagem livre pela membrana, mantém o balanço elétrico e osmótico da célula. $\mathrm{O}$ enxofre é um componente de certos aminoácidos, vitaminas e metabólitos. O cálcio tem várias funções pela sua ligação com a membrana da célula, influenciando ainda o funcionamento dos microtúbulos e microfilamentos (Garraway \& Evans, 1984). O sódio é um micronutriente importante na absorção de fósforo (Siegenthaler et al., 1967, Sykes \& Porter, 1973), podendo ainda aumentar a permeabilidade da membrana para potássio (Jennings \& Aynsley, 1971), açúcares e açúcares-álcoois (Allaway \& Jennings, 1970; Jennings \& Austin, 1973). Nesse estudo, os sais apresentaram grande importância na produção de Batkoa sp., Furia sp. e especialmente $N$. floridana. A forma de atuação desses minerais não está clara, pois o sódio e potássio podem atuar não somente como nutrientes mas também como reguladores da pressão osmótica.

Os fungos necessitam de nitrogênio para a síntese de diversos constituintes da célula, incluindo aminoácidos e proteínas, purinas, pirimidinas e ácidos nucleicos, glucosamina e quitina, e várias vitaminas. Na célula, os aminoácidos atuam geralmente como fontes de nitrogênio para a sintetização de moléculas mais complexas. Portanto, as fontes de nitrogênio usadas nos meios de cultura são geralmente convertidas em aminoácidos, dentro da célula, antes de serem utilizadas pelo organismo (Garraway \& Evans, 1984).

O uso de sais e aminoácidos visando a produção de Entomophthorales já foi avaliado por Wolf (1951) quando realizou o primeiro estudo de produção desses fungos em meio quimicamente definido. Verificou-se que Entomophthora apiculata e E. coronata podem ser produzidos em meio sintético a base de dextrose-asparagina-sais. Em seguida, Smith (1953) obteve bom crescimento de E. coronata também no meio definido contendo sais minerais, arginina (hidrocloreto), dextrose e água destilada.

Quanto as vitaminas, parecem ter pouca importância nos meios de cultura para a produção de Entomophthorales. Wolf (1951) citou que as espécies E. apiculata e E. coronata são autotróficas quanto às vitaminas e outros fatores de crescimento, enquanto que Latgé (1981) caracterizou os gêneros Entomophthora, Erynia, Zoophthora, Conidiobolus e Basidiobolus em um mesmo grupo quanto a habilidade dos mesmos em 
sintetizar vitaminas e utilizar nitrogênio mineral ou orgânico, ou ainda de oxidar e reduzir formas de enxofre.

Efeito de fontes de carbono - As três espécies de Entomophthorales se assemelharam quanto ao crescimento nos meios com diferentes fontes de carbono (Figuras 9 e 10).

O meio preparado com $2,66 \%$ de glucose proporcionou a maior produção para as três espécies de fungo, com incremento significativamente maior que nos demais tratamentos para as espécies Batkoa sp. $(\mathrm{F}=27,72 ; \mathrm{P}=0,000)$ e Furia sp. $(\mathrm{F}=48,99 ; \mathrm{P}=$ 0,000). A adição de baixas concentrações de glucose, frutose ou maltose no meio contendo sucrose proporcionou pequeno aumento na produção de Batkoa sp. e Furia sp., dificultando a classificação dessas fontes de carbono. Para o fungo $N$. floridana, a adição desses açúcares proporcionou um aumento na produção do patógeno, com maior rendimento para o meio com maltose, seguido daqueles com glucose e frutose. O açúcar inositol não apresentou efeito na produção desses fungos, sendo as produções obtidas nos meios com essa fonte de carbono e com apenas sucrose, as menores do experimento.

As fontes de carbono possuem duas funções essenciais na fisiologia de fungos: suprem a necessidade de carbono para a síntese de importantes componentes como os carboidratos, proteínas, lipídeos e ácidos nucleicos; atuam, durante a oxidação, como fonte de energia para o funcionamento de processos essenciais na vida do fungo. Os fungos são seletivos na utilização de açúcares e outros nutrientes, diferindo dentro de espécies e até mesmo isolados quanto a suas exigências por esses nutrientes (Garraway \& Evans, 1984).

A menor produção de Batkoa sp., Furia sp. e N. floridana no meio com sucrose, comparado ao meio com $2,66 \%$ de glucose, sugere que essas espécies não produzem invertase (utilizada na hidrólise das moléculas de sucrose), necessitando de carboidratos prontamente disponíveis como a glucose. Vários estudos têm mostrado a incapacidade de Entomophthorales na produção de invertase e a preferência desses organismos por monossacarídeos como a glucose, frutose e maltose (Latgé, 1975a; Grundschober et al., 1998). Cooke \& Rayner (1984) afirmaram que fungos da Divisão Zygomicotina são incapazes de metabolizar sucrose. 


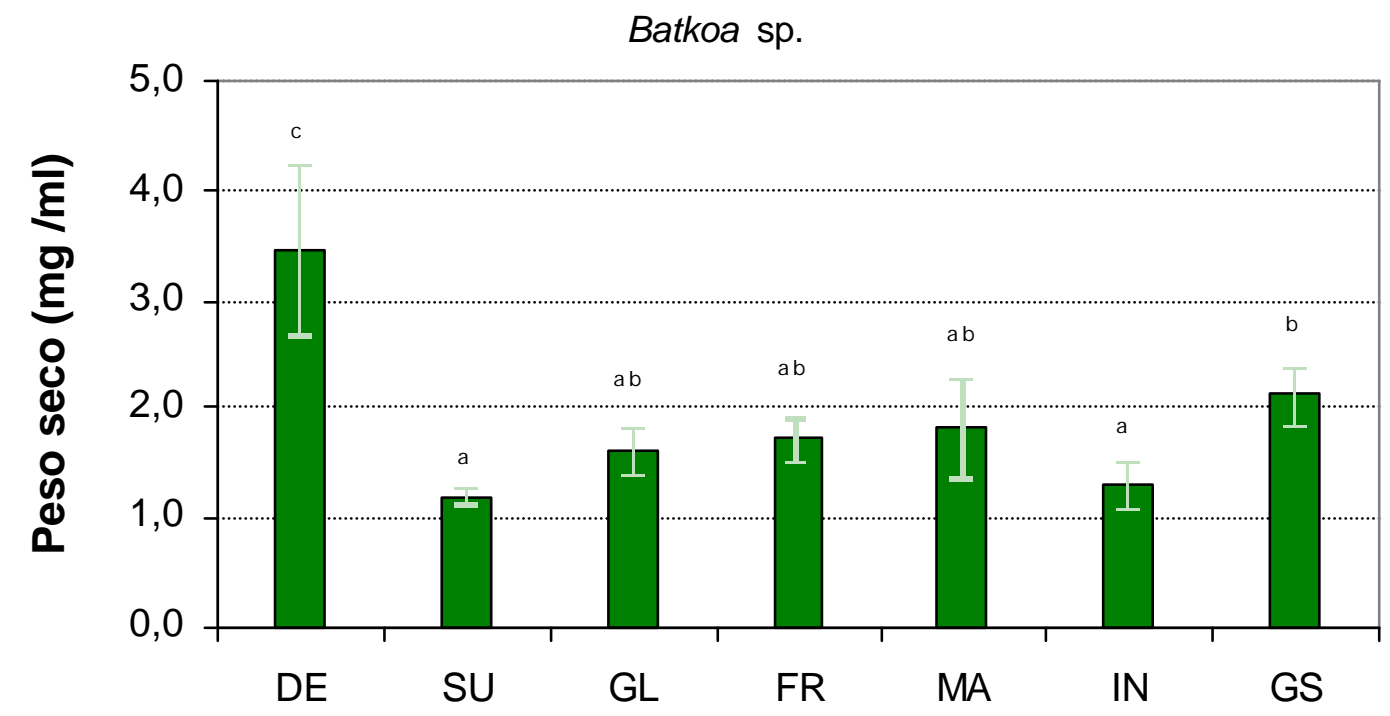

Furia sp.

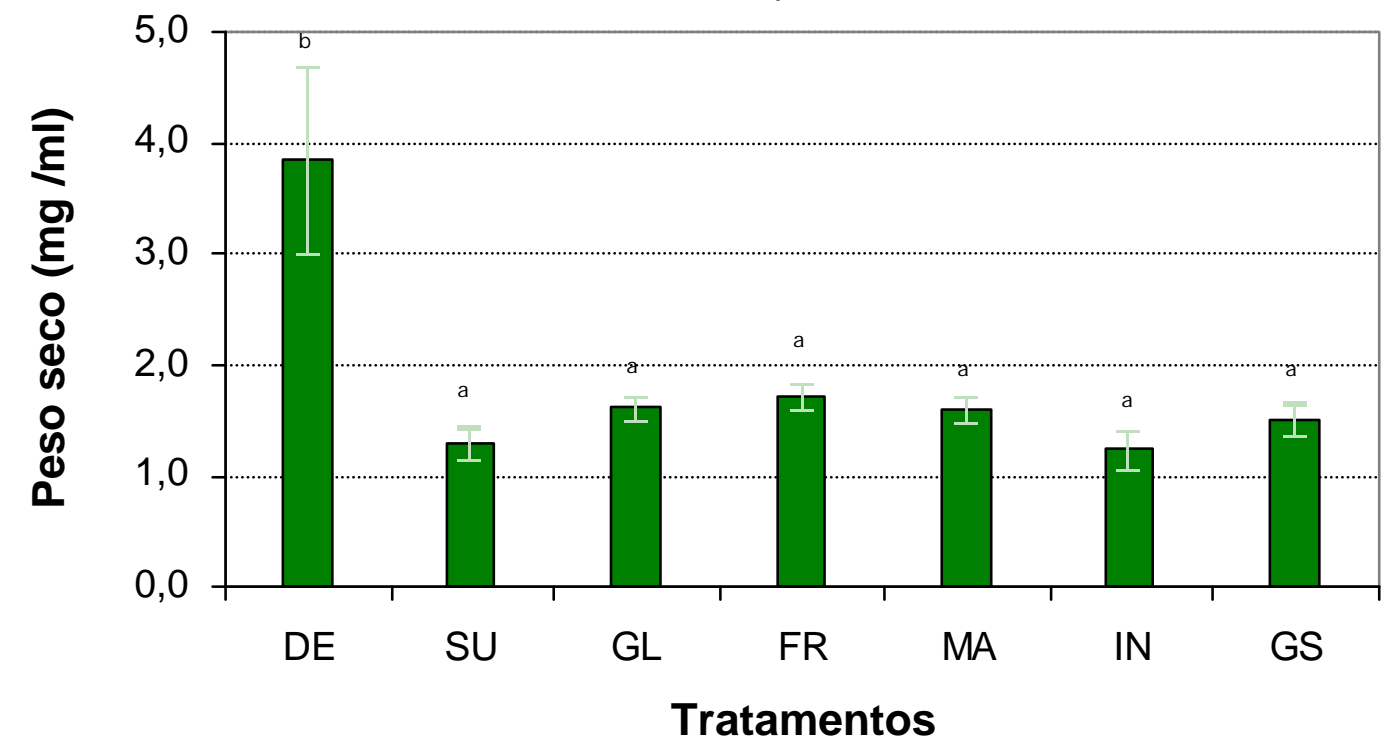

Figura 9 - Produção de biomassa dos fungos Batkoa sp. e Furia sp. em meios líquidos. DE $=$ glucose $(2,66 \%) ; \mathrm{SU}=$ sucrose $(2,66 \%) ; \mathrm{GL}=$ sucrose $(2,66 \%)+$ glucose $(0,1 \%) ; \mathrm{FR}=\operatorname{sucrose}(2,66 \%)+$ frutose $(0,1 \%) ; \mathrm{MA}=\operatorname{sucrose}(2,66 \%)+$ maltose $(0,1 \%) ;$ IN $=$ sucrose $(2,66 \%)+$ inositol $(0,1 \%) ;$ GS $=$ Grace's suplementado. Tratamentos com a mesma letra não diferem entre si pelo teste de Tukey, ao nível de 5\% de probabilidade. Barras = desvio padrão. 


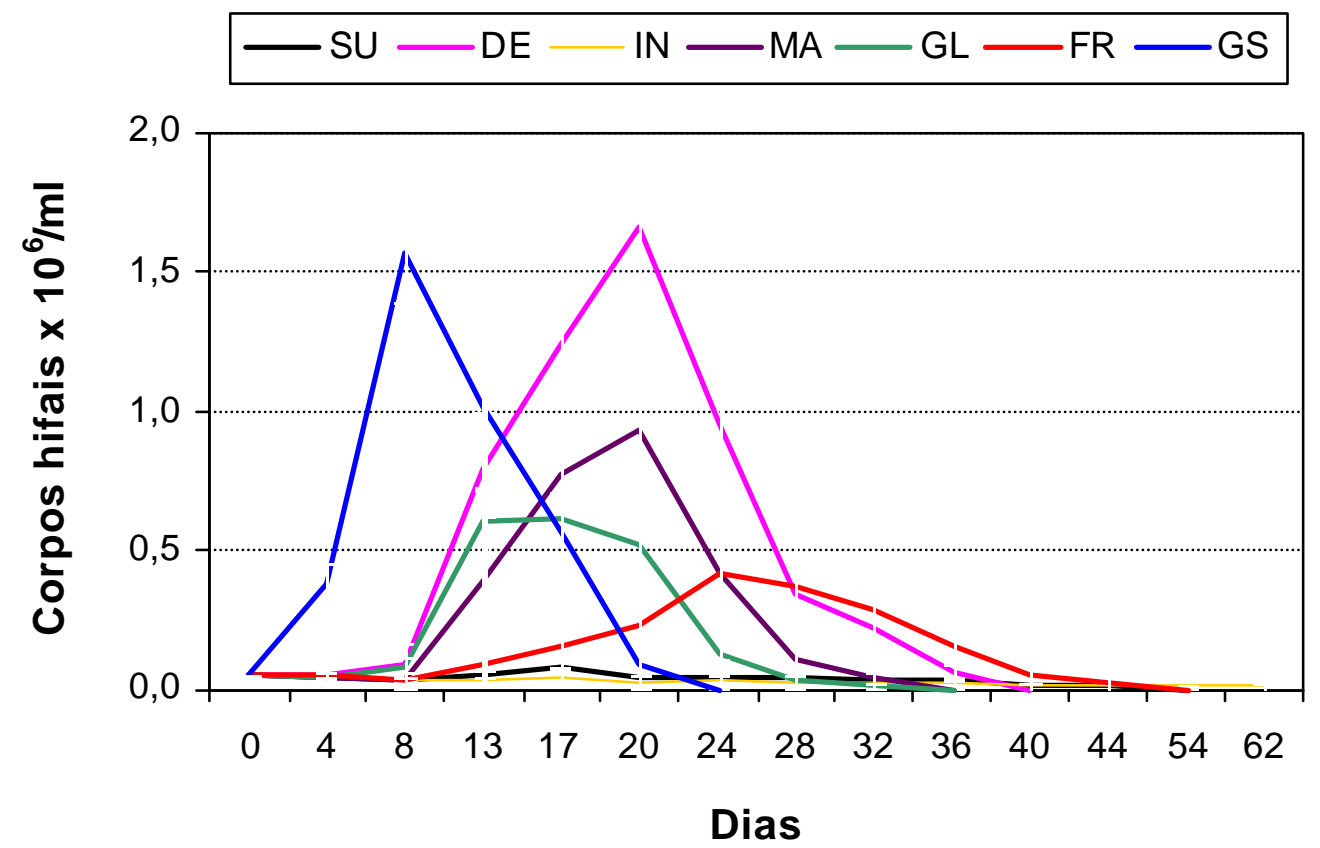

Figura 10 - Produção de Neozygites floridana em meios líquidos. DE = glucose $(2,66 \%)$; $\mathrm{SU}=$ sucrose $(2,66 \%) ; \mathrm{GL}=$ sucrose $(2,66 \%)+$ glucose $(0,1 \%) ; \mathrm{FR}=$ sucrose $(2,66 \%)+$ frutose $(0,1 \%) ; \mathrm{MA}=\operatorname{sucrose}(2,66 \%)+$ maltose $(0,1 \%) ; \mathrm{IN}=$ sucrose $(2,66 \%)+$ inositol $(0,1 \%) ; \mathrm{GS}=$ Grace's suplementado. Barras = desvio padrão.

Para N. floridana, o meio contendo 2,66\% de glucose proporcionou uma produção ligeiramente maior que o meio Grace's suplementado, sem diferir significativamente. Porém, esse último meio permitiu uma maior taxa de crescimento do patógeno, sendo um dos prováveis motivos a presença de aminoácidos em maior concentração no mesmo. Os aminoácidos contribuem para acelerar a taxa de reprodução do fungo já que atuam na síntese de diversos constituintes da célula, especialmente dos ácidos nucleicos, os quais estão diretamente associados a reprodução (Garraway \& Evans, 1984).

Efeito de fontes de nitrogênio - Neste estudo, Batkoa sp., Furia sp. e $N$. floridana não apresentaram a mesma resposta quando avaliados em meios com diferentes fontes de nitrogênio (Figura 11). Extrato de levedura proporcionou a maior produção para Batkoa sp., embora não tenha diferenciado significativamente do LD, EC, LY, GS e GE (F 
= 7,40; $\mathrm{P}=0,000)$. O extrato de carne proporcionou a maior produção para Furia sp., diferindo significativamente dos demais tratamentos $(\mathrm{F}=49,20 ; \mathrm{P}=0,000)$, enquanto o meio Grace's suplementado manteve-se o melhor para $N$. floridana, não diferindo apenas do meio peptona $(\mathrm{F}=101,12 ; \mathrm{P}=0,000)$, o qual proporcionou um rendimento ligeiramente menor. O leite desnatado proporcionou a segunda maior produção para Batkoa sp. e Furia sp. e a terceira maior para $N$. floridana.

De forma geral, fungos Entomophthorales parecem apresentar a mesma exigência para sais, aminoácidos e açúcares, mas não para fontes de nitrogênio. Latgé (1981) também constatou semelhança entre os Entomophthorales quanto as exigências para sais, aminoácidos e açúcares. Os meios a base dos subprodutos vegetais soja e xarope de milho apresentaram produção relativamente baixa para as três espécies de fungos, demonstrando a preferência desses organismos para fontes que forneçam moléculas de proteína já hidrolisadas, como extrato de levedura, extrato de carne e peptona. Os componentes proteína hidrolisada de soja e caseína hidrolisada, os quais são bastante ricos em nitrogênio, resultaram em baixa produção para as três espécies de fungos. Isso se deve, provavelmente, a algum efeito tóxico resultante de concentrações extremamente elevadas de nitrogênio ou de algum componente específico, presente nos meios de cultura.

Lactalbumina hidrolisada e yeastolate não se destacaram na produção das espécies, tendo o primeiro componente proporcionado menor produção em relação ao segundo, o que já foi observado por Leite et. al. (2000) para o fungo $N$. floridana. Esses componentes, avaliados isoladamente, proporcionaram menores rendimentos para Batkoa sp. e $N$. floridana do que quando avaliados em conjunto (LY), o que sugere que os mesmos se diferenciam quanto a alguns tipos ou concentrações de nutrientes fornecidos aos organismos, vindo a se completarem na nutrição dessas espécies quando fornecidos em conjunto. 

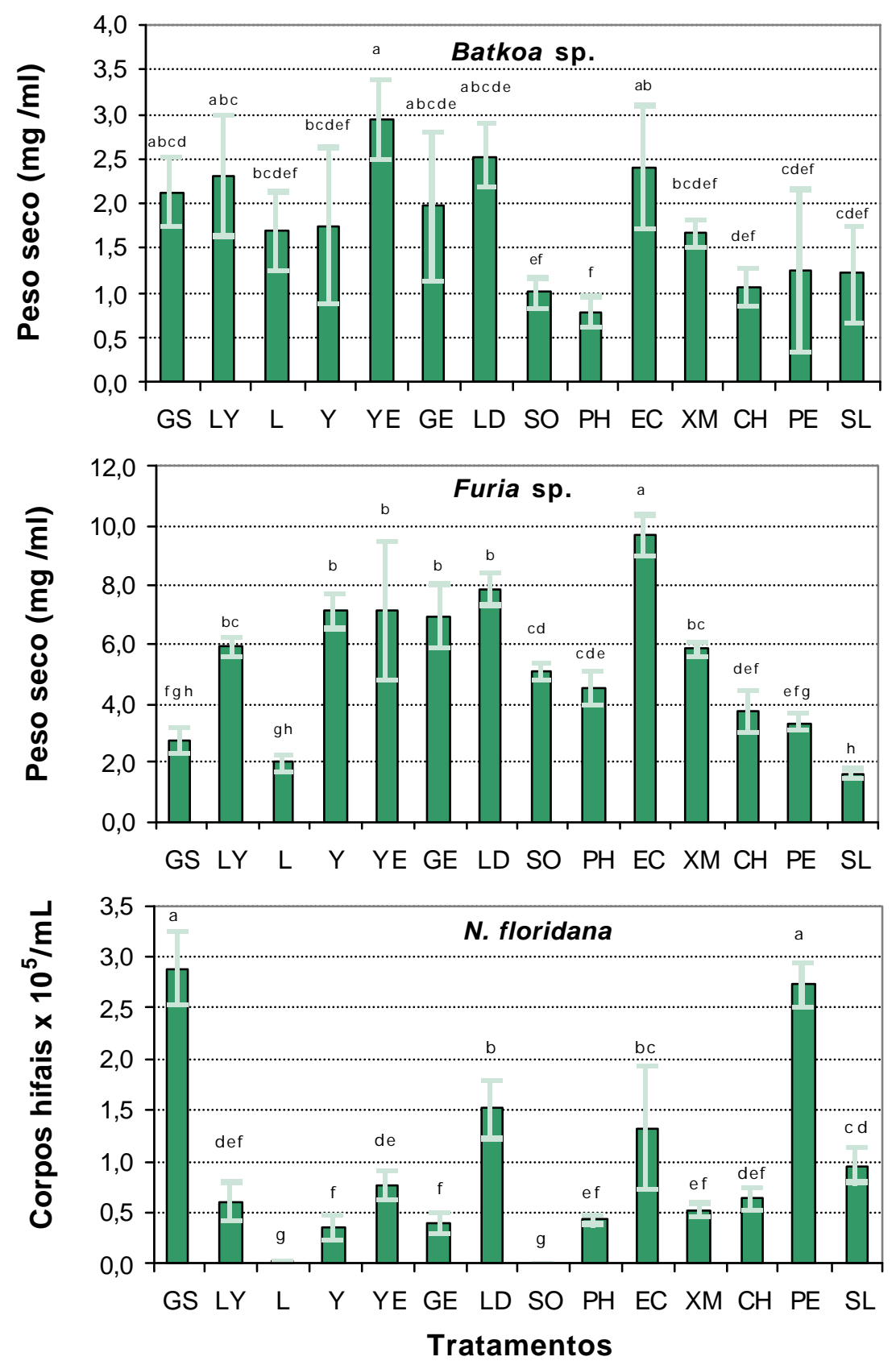

Figura 11 - Produção de Batkoa sp., Furia sp. e Neozygites floridana em meios de cultura líquidos com diferentes fontes de nitrogênio. GS = meio Grace's suplementado; $\mathrm{LY}=$ lactalbumina hidrolisada + yeastolate; $\mathrm{L}=$ lactalbumina hidrolisada; $\mathrm{Y}=$ yeastolate; $\mathrm{YE}=$ extrato de levedura; $\mathrm{GE}=$ gema de ovo; $\mathrm{LD}=$ leite desnatado; $\mathrm{SO}=$ soja $; \mathrm{PH}=$ proteína hidrolisada de soja $; \mathrm{EC}=$ extrato de carne; $\mathrm{XM}=$ xarope de milho; $\mathrm{CH}=$ ácido de caseína hidrolisada; $\mathrm{PE}=$ peptona; $\mathrm{SL}=$ soro de leite. Tratamentos com a mesma letra não diferem entre si pelo teste de Tukey $(\alpha=0,05)$. Barras $=$ desvio padrão. 
Os fungos Batkoa sp. e Furia sp. parecem ser semelhantes quanto a seletividade para fontes de nitrogênio, entretanto, a segunda espécie é mais adaptada a ambientes adversos, pois demonstra um crescimento muito mais rápido, resultando em uma produção maior em relação a Batkoa sp. Já $N$. floridana, comportou-se como o mais exigente em sais e mais seletivo para fontes de nitrogênio, o que pode ser explicado pela sua especificidade para ácaros. O meio Grace's suplementado manteve-se o melhor para N. floridana, confirmando os resultados obtidos por Leite et al. (2000) que destacaram esse meio como o melhor dentre vários outros avaliados. No entanto, o meio contendo peptona não diferiu significativamente do meio Grace's, sugerindo a realização de novos estudos visando avaliar o efeito das três melhores fontes de nitrogênio (peptona, leite desnatado e extrato de carne), em diferentes combinações e concentrações, na produção desse patógeno. Esses estudos poderão resultar no desenvolvimento de um meio de cultura que proporcione maior produção de $N$. floridana, de custo bastante inferior, comparado ao meio Grace's suplementado.

\subsection{Conclusões}

Os ensaios e observações realizadas permitiram concluir que:

1. Batkoa sp., Furia sp. e N. floridana se assemelham quanto ao crescimento em meios contendo sais, vitaminas e aminoácido, e em meio completo;

2. A adição de sais ao meio básico proporciona um aumento significativo na produção das três espécies de fungos, e maior do que a adição de vitaminas e aminoácidos;

3. O meio contendo $2,66 \%$ de glucose proporciona uma produção das três espécies de fungo significativamente maior do que o meio com 2,66\% de sacarose (sucrose);

4. A adição de $0,1 \%$ de monossacarídeos no meio com $2,66 \%$ de sacarose não aumenta significativamente a produção dos fungos;

5. Batkoa sp., Furia sp. e N. floridana se assemelham quanto ao crescimento em meios contendo diferentes fontes de carbono, mas se diferenciam em meios com diferentes fontes de nitrogênio. 


\section{EFEITO DE FONTES DE NITROGÊNIO NA PRODUÇÃo DE ENTOMOPHTHORALES}

\section{Resumo}

Os fungos Entomophthorales Batkoa sp., Furia sp. e Neozygites floridana têm sido estudados para o controle biológico de pragas, sendo os dois primeiros patógenos empregados para o controle das cigarrinhas das pastagens e cana-de-açúcar, e o último para o controle de alguns ácaros de importância agrícola. Para o desenvolvimento desses agentes como bioinseticida, é importante o estabelecimento de meios de cultura que maximizem a produção dos mesmos, com menor custo para obtenção. Esse estudo avaliou o efeito de quatro fontes de nitrogênio comumente usadas na produção de Entomophthorales, em diferentes combinações e concentrações, tendo em vista a produção em meio líquido de micélio ou corpos hifais de Batkoa sp., Furia sp. e $N$. floridana. O extrato de levedura proporciona maior produção de Batkoa sp. A concentração de 0,5\% de extrato de levedura é a mais adequada para a produção vegetativa desse fungo. A combinação de extrato de levedura + extrato de carne + leite desnatado proporciona a maior produção de Furia sp. A combinação de extrato de levedura + leite desnatado proporciona o segundo maior rendimento de Furia sp., sendo mais adequada para a produção do fungo devido ao menor custo. A concentração de $1 \%$ da mistura dessas fontes de nitrogênio é adequada para a produção vegetativa de Furia sp. A combinação de extrato de levedura + peptona + leite desnatado proporciona a maior produção de $N$. floridana. A concentração de 3\% da mistura dessas fontes de nitrogênio é adequada para a produção vegetativa desse fungo. 


\section{Summary}

\section{Effect of nitrogen sources on the growth of Entomophthorales fungi}

The Entomophthorales fungi Batkoa sp., Furia sp. and Neozygites floridana have been studied for biological control of pests: the first two pathogens for the control of spittlebug pests of pasture and sugarcane, and the third for the control of mites of agricultural importance. For the development of these agents as biopesticides and bioacaricides, it is important to have available culture media that maximize production at low cost. The research reported here evaluates in different combinations and concentrations, the effects of 4 sources of nitrogen on production of mycelium or hyphal bodies in liquid media of all three species. Yeast extract allows the highest production of Batkoa sp. The concentration of $0.5 \%$ yeast extract is the most suitable for vegetative growth of Batkoa sp. The combination of yeast extract + beef extract + skim milk allows the highest production of Furia sp. The combination of yeast extract + skim milk allows the second highest production of Furia sp., and is the most suitable for mass production due to the lower cost. The $1 \%$ concentration of the mixture of these nitrogen sources is suitable for vegetative growth of Furia sp. The combination of yeast extract + peptone + skim milk allows the highest production of $N$. floridana. The $3 \%$ concentration of the mixture of these nitrogen sources is suitable for the vegetative growth of $N$. floridana. 


\subsection{Introdução}

Os fungos Entomophthorales Batkoa sp., Furia sp. e Neozygites floridana (Weiser \& Muma) Remaudière \& Keller têm sido estudados para o controle biológico de pragas, sendo os dois primeiros patógenos empregados para o controle das cigarrinhas das pastagens e cana-de-açúcar, e o último para o controle de alguns ácaros de importância agrícola, incluindo o ácaro-rajado, Tetranychus urticae Koch (Alvares et al. 1991). Para o desenvolvimento desses agentes como bioinseticida e bioacaricida, é importante o estabelecimento de meios de cultura que maximizem a produção dos mesmos, com menor custo para obtenção. Isso pode ser conseguido selecionando, no preparo dos meios, os componentes mais favoráveis ao crescimento desses patógenos, além das concentrações mais econômicas e que promovam maior rendimento.

Sawyer (1929) realizou um dos trabalhos mais extensos sobre produção de Entomophthorales "in vitro". Avaliou o crescimento de Entomophthora sphaerosperma e Empusa sp. em 40 meios de cultura, com melhores resultados em meios a base de batata, carne de peixe e carne de porco. Observou que o meio líquido favorece o crescimento de micélio enquanto que o meio sólido favorece o crescimento de corpos hifais e a reprodução por conídios. Verificou-se ainda que essas espécies preferem fontes de proteínas que sejam rapidamentes hidrolizadas pelas enzimas proteolíticas secretadas pelos patógenos.

Depois disso foram realizados diversos estudos sobre produção "in vitro" de Entomophthorales (Latgé, 1975b; Latgé, 1981; Latgé \& Sanglier, 1985, Leite et al., 1991), porém muito pouco foi pesquisado sobre o efeito de fontes de nitrogênio em diferentes combinações e concentrações. Esse estudo avaliou o efeito de quatro fontes de nitrogênio comumente usadas na produção de Entomophthorales, em diferentes combinações e concentrações, tendo em vista a produção em meio líquido de Batkoa sp., Furia sp. e N. floridana.

\subsection{Material e Métodos}

As fontes de nitrogênio utilizadas para a realização do ensaio foram extrato de levedura, extrato de carne, peptona e leite desnatado. 
Efeito de combinações - Foram considerados 17 tratamentos, representados pelas seguintes fontes de nitrogênio: a) leite desnatado (LM); b) extrato de levedura (YE); c) peptona (PE); d) extrato de carne (EC); e) LM+YE; f) LM+PE; g) LM+EC; h) YE+PE; i) $\mathrm{YE}+\mathrm{EC}$; j) PE+EC; k) LM+YE+PE; l) LM+YE+EC; m) LM+PE+EC; n) YE+PE+EC; o) $\mathrm{LM}+\mathrm{YE}+\mathrm{PE}+\mathrm{EC}$; p) lactalbumina hidrolisada + yeastolate (LY); e q) meio Grace's suplementado com lactalbumina hidrolizada mais yeastolate (HyQ ${ }^{\circledR}$ TNM-FH, \#SH30280.02) (GS). Os tratametos LY e GS foram considerados como testemunhas.

Os meios foram preparados utilizando-se as fontes de nitrogênio isoladas ou em mistura, na concentração total de $1 \%$, adicionados de $2,66 \%$ de glucose (dextrose) e dos sais $\mathrm{CaCh}_{2} \cdot 2 \mathrm{H}_{2} \mathrm{O}(0,06 \%), \mathrm{KCl}(0,28 \%), \mathrm{MgCl}_{2} \cdot 6 \mathrm{H}_{2} \mathrm{O}(0,16 \%), \mathrm{MgSO}_{4} \cdot 7 \mathrm{H}_{2} \mathrm{O}(0,2 \%)$, $\mathrm{NaHCO}_{3}(0,03 \%)$ e $\mathrm{NaH}_{2} \mathrm{PO}_{4} \cdot \mathrm{H}_{2} \mathrm{O}(0,1 \%)$. Esses componentes foram esterilizados em soluções separadas antes de serem misturados. Isso se deveu a dois motivos: - a autoclavagem do açúcar e das fontes de nitrogênico em uma mesma solução resulta em efeitos deletérios a $N$. floridana; - a autoclavagem dos sais misturados em uma mesma solução resulta na precipitação dos minerais.

Portanto, o açúcar e as fontes de nitrogênico foram autoclavados em soluções contendo o dobro de suas concentrações para, em seguida, serem misturados em partes iguais. Para a esterilização prévia dos sais, soluções dos minerais altamente concentradas foram filtradas em filtro de 0,22 $\mu \mathrm{m}$, com o auxílio de uma seringa. Visando-se evitar a reação entre os sais nas soluções altamente concentradas, as mesmas foram preparadas com apenas dois tipos de sais (compatíveis entre si) cada uma, empregando-se a mistura de $\mathrm{CaCl}_{2} \cdot 2 \mathrm{H}_{2} \mathrm{O}$ com $\mathrm{KCl}, \mathrm{MgCh}_{2} \cdot 6 \mathrm{H}_{2} \mathrm{O}$ com $\mathrm{NaH}_{2} \mathrm{PO}_{4} \cdot \mathrm{H}_{2} \mathrm{O}$, e $\mathrm{MgSO}_{4} \cdot 7 \mathrm{H}_{2} \mathrm{O}$ com $\mathrm{NaHCO}_{3}$. A primeira mistura foi preparada na concentração de $50 \%$ para cada sal, enquanto que a segunda e terceira na concentração de $100 \%$.

O preparo dos meios foi finalizado com o ajuste do $\mathrm{pH}$ para 6,2, utilizando-se soluções esterilizadas de $\mathrm{HCl}(0,1 \%)$ e $\mathrm{NaOH}(10 \%)$.

Para os fungos Batkoa sp. e Furia sp. foram utilizadas 6 repetições por tratamento, sendo cada repetição representada por um tubo plástico $(2,8 \times 11,8 \mathrm{~cm})$ de 50 $\mathrm{mL}$ contendo $8 \mathrm{~mL}$ do meio de cultura. O fungo utilizado para inoculação dos tubos foi obtido de uma colônia desenvolvida em meio de cultura sólido, constituído de extrato de levedura $(2 \%)$, dextrose $(2 \%)$ e ágar $(1,5 \%)$. Cada tubo foi inoculado com um pedaço de 0,3 x $0,3 \mathrm{~cm}$ do meio colonizado. Após a inoculação, os tubos foram tampados e 
acondicionados em um agitador orbital, ajustado para $200 \mathrm{rpm}$, na temperatura de $23{ }^{\circ} \mathrm{C}$ e fotofase de 14 horas. As tampas foram mantidas levemente desatarraxadas, visando permitir a troca de gases.

Após um período de 7 dias, procedeu-se a avaliação quanto a produção de massa seca dos patógenos nos diferentes meios de cultura. Para isso, o fungo foi filtrado sobre papel de filtro de $45 \mathrm{~mm}$ de diâmetro com o auxílio de uma bomba de vácuo, descartando-se o meio de cultura. Os papéis de filtro, antes de serem utilizados, foram mantidos por 24 horas a $70{ }^{\circ} \mathrm{C}$ e, em seguida, pesados. Após a filtragem, os papéis de filtro com o fungo foram submetidos ao mesmo procedimento.

Para o fungo $N$. floridana foram utilizadas 5 repetições por tratamento, sendo cada repetição representada por um tubo plástico $(1,5 \times 9,5 \mathrm{~cm})$ de $8 \mathrm{~mL}$ contendo $2 \mathrm{~mL}$ do meio de cultura. Cada tubo foi inoculado com $0,1 \mathrm{~mL}$ de uma suspensão de corpos hifais de N. floridana, obtida de uma colônia desenvolvida no meio líquido Grace's suplementado. Após a inoculação, os tubos foram tampados, agitados em vortex e acondicionados em um agitador orbital, ajustado para $200 \mathrm{rpm}$, na temperatura de $23{ }^{\circ} \mathrm{C}$ e fotofase de 14 horas. Os tubos foram posicionados com inclinação de $45^{\circ}$ no agitador, sendo suas tampas mantidas levemente desatarraxadas.

As avaliações foram feitas a cada 2 dias, determinando-se a concentração de corpos hifais /mL para cada tubo. $\mathrm{Na}$ instalação do experimento, também foram inoculados outros 5 tubos, contendo $2 \mathrm{~mL}$ de água destilada por tubo, com o objetivo de determinar a concentração inicial de corpos hifais. A concentração do fungo foi determinada com o auxílio de uma câmara de Newbauer e um microscópio óptico com contraste de fase, utilizando-se a objetiva de 100 vezes. Para isso os tubos foram previamente agitados em vortex.

Efeito de concentrações - Foram utilizadas as fontes ou combinações de fontes selecionadas na etapa anterior, as quais proporcionaram maior produção para cada patógeno: extrato de levedura para Batkoa sp.; extrato de levedura + extrato de carne + leite desnatado para Furia sp; e extrato de carne + leite desnatado + peptona para $N$. floridana.

Foram realizados dois experimentos, considerando-se no primeiro 5 tratamentos para cada espécie, representados pelas concentrações totais de 1, 2, 3 e $4 \%$ das fontes de nitrogênio, isoladas ou em combinação, e pelo meio Grace's suplementado (Testemunha). 
Em uma segunda etapa foram considerados 6 tratamentos para cada espécie, representados pelas concentrações totais de 0,$25 ; 0,5 ; 0,75 ; 1,0$ e $2,0 \%$ das fontes isoladas ou em combinação, e pelo meio Grace's suplementado (Testemunha).

Os meios foram preparados com 2,66\% de glucose + sais. Os sais foram esterilizados por autoclavagem antes de serem adicionados nos diferentes meios, utilizando-se soluções separadas para cada sal, nas concentrações de $50 \%$ para $\mathrm{CaCl}_{2} .2 \mathrm{H}_{2} \mathrm{O}$ e $\mathrm{KCl}$, e $100 \%$ para $\mathrm{MgCh} \cdot 6 \mathrm{H}_{2} \mathrm{O}, \mathrm{NaH}_{2} \mathrm{PO}_{4} \cdot \mathrm{H}_{2} \mathrm{O}, \mathrm{MgSO}_{4} \cdot 7 \mathrm{H}_{2} \mathrm{O}$ e $\mathrm{NaHCO}_{3}$. Para o restante da metodologia, empregaram-se os mesmos procedimentos usados no estudo anterior (efeito de combinações), utilizando-se 10 repetições para os experimentos com as concentrações maiores, mantendo-se 6 repetições para aqueles com concentrações menores.

Os experimentos foram submetidos a análise de variância e as médias comparadas pelo teste de Tukey $(\mathrm{P}<0,05)$.

\subsection{Resultados e Discussão}

Efeito de combinações - Extrato de levedura (YE) proporcionou a maior produção para Batkoa sp. (Figura 12), embora não tenha diferenciado significativamente de 10 outros tratamentos em escala decrescente de valores: YE+EC; EC; YE+PE; $\mathrm{LD}+\mathrm{YE}+\mathrm{EC}$; LD+YE+PE; LD+YE; COMPLETO; YE+PE+EC; LY e PE+EC (F = 5,77; P $=0,000)$. Os três melhores tratamentos não possuem leite desnatado e peptona como componentes, sugerindo que essas fontes de nitrogênio, apesar de não ter ocorrido diferença estatística, possuem menor importância para a produção de Batkoa sp.

Para Furia sp. (Figura 12), a combinação de leite desnatado, extrato de levedura e extrato de carne (LD+EL+EC) proporcionou a maior produção, embora não tenha diferenciado significativamente dos 9 seguintes melhores tratamentos (LD+YE, $\mathrm{LD}+\mathrm{PE}+\mathrm{EC}, \mathrm{LD}+\mathrm{EC}, \mathrm{EC}, \mathrm{COMPLETO}, \mathrm{LD}+\mathrm{YE}+\mathrm{PE}, \mathrm{LD}, \mathrm{PE}+\mathrm{EC}$ e $\mathrm{YE}+\mathrm{EC})(\mathrm{F}=9,25 ; \mathrm{P}$ $=0,000)$. Os quatro melhores tratamentos possuem o leite desnatado como componente, sugerindo que essa fonte de nitrogênio possui maior importância para a produção de Furia sp. do que para Batkoa sp. 
Batkoa sp.

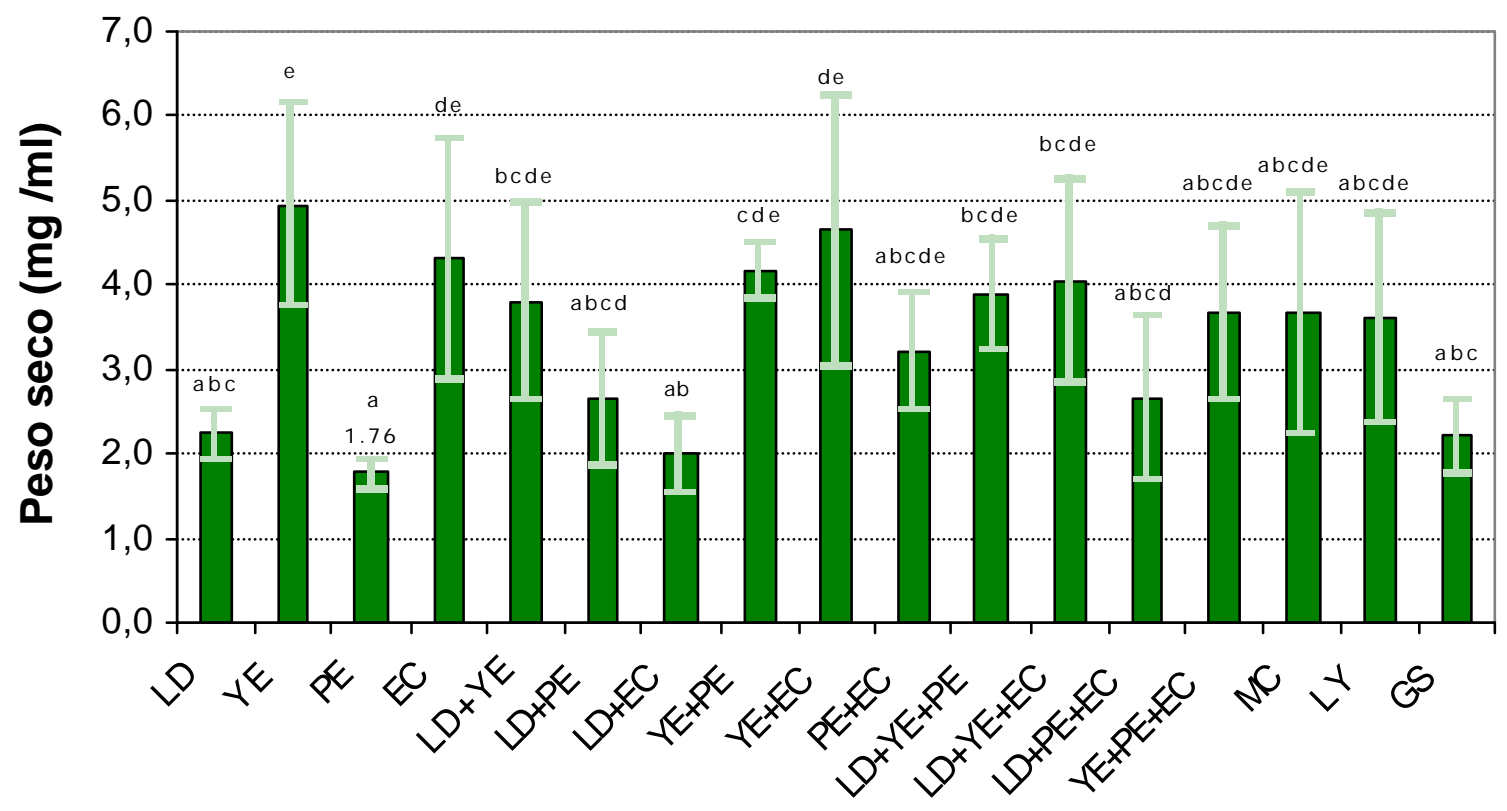

Furia sp.

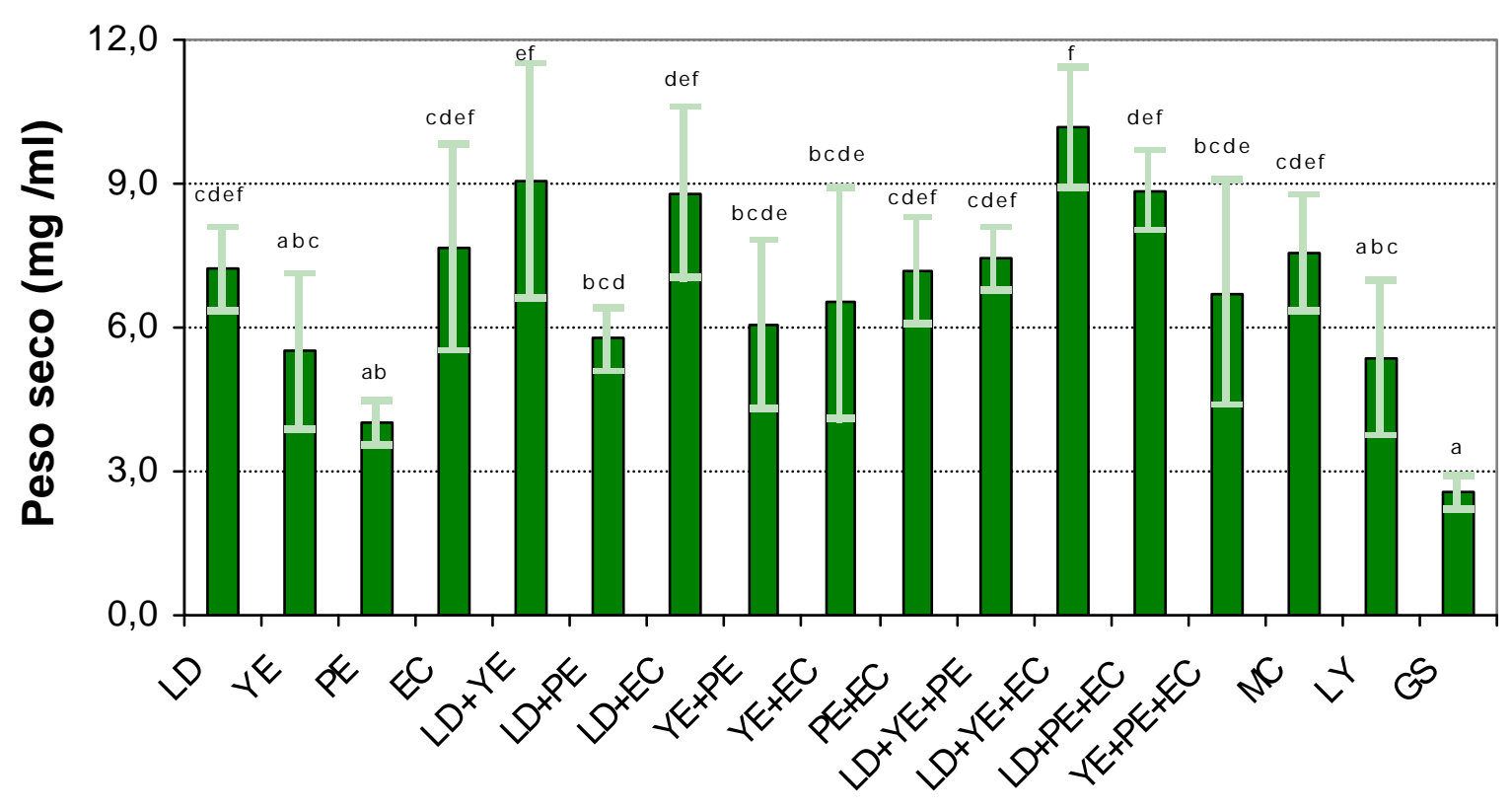

Tratamentos

Figura 12 - Produção de Batkoa sp. e Furia sp. em meios líquidos a base de diferentes combinações dos componentes leite desnatado (LD), extrato de levedura $(\mathrm{YE})$, peptona $(\mathrm{PE})$ e extrato de carne $(\mathrm{EC}) . \mathrm{MC}=$ meio completo; $\mathrm{LY}=$ lactalbumina hidrolisada + yeastolate; GS $=$ Grace's suplementado. Tratamentos com a mesma letra não diferem entre si pelo teste de Tukey, ao nível de $5 \%$ de probabilidade. Barras = desvio padrão. 
Para N. floridana (Figura 13), a combinação de leite desnatado, peptona e extrato de carne proporcionou uma das maiores concentrações de corpos hifais dentre todos os tratamentos, e a maior dentre aqueles com pico de crescimento nas duas primeiras semanas de avaliação, seguido ligeiramente abaixo pelo meio Grace's suplementado. Extrato de levedura avaliado isoladamente, embora tenha proporcionado o maior pico de produção do experimento, apresentou o crescimento mais lento do patógeno, já que o pico ocorreu aos 38 dias após a inoculação.

Em geral, os fungos não apresentaram os mesmos comportamentos quando cultivados nos meios com diferentes fontes de nitrogênio, sugerindo que essas diferentes exigências nutricionais possam ser fatores envolvidos na relativa especificidade de Entomophthorales aos seus hospedeiros. Outros fungos Entomophthorales também tem mostrado diferenças no crescimento em meios preparados com diferentes aminoácidos inorgânicos (Wolf, 1951; Latgé, 1975b).

$N$. floridana parece ser o mais seletivo entre as espécies, com grande variação na produção e no tempo para ocorrer o pico de crescimento nos diferentes meios. Esse fungo provavelmente exige aminoácidos, visto que leite desnatado e peptona, os quais são ricos nesses nutrientes, aceleraram a taxa de reprodução. Todos os picos de crescimento que ocorreram nas primeiras duas semanas foram observados nos meios contendo leite desnatado, peptona ou ambos os componentes. O meio contendo esses dois componentes como únicas fontes de nitrogênio antecipou o pico de crescimento para a primeira semana, proporcionando maior produção quando adicionado de extrato de carne. Nolan (1993) escolheu caldo de soja tripiticaseína como complemento para um meio básico na produção de Entomophaga aulicae, porque o mesmo poderia atuar como uma fonte adicional de aminoácido e outros elementos não definidos, de baixo custo. O gênero Neozygites é provavelmente exigente para fontes mais complexas de nitrogênio, já que $N$. parvospora cresceu em meio Grace's suplementado somente quando o meio foi adicionado de hemolinfa de lepidóptero (Grundschober et al., 1998). 

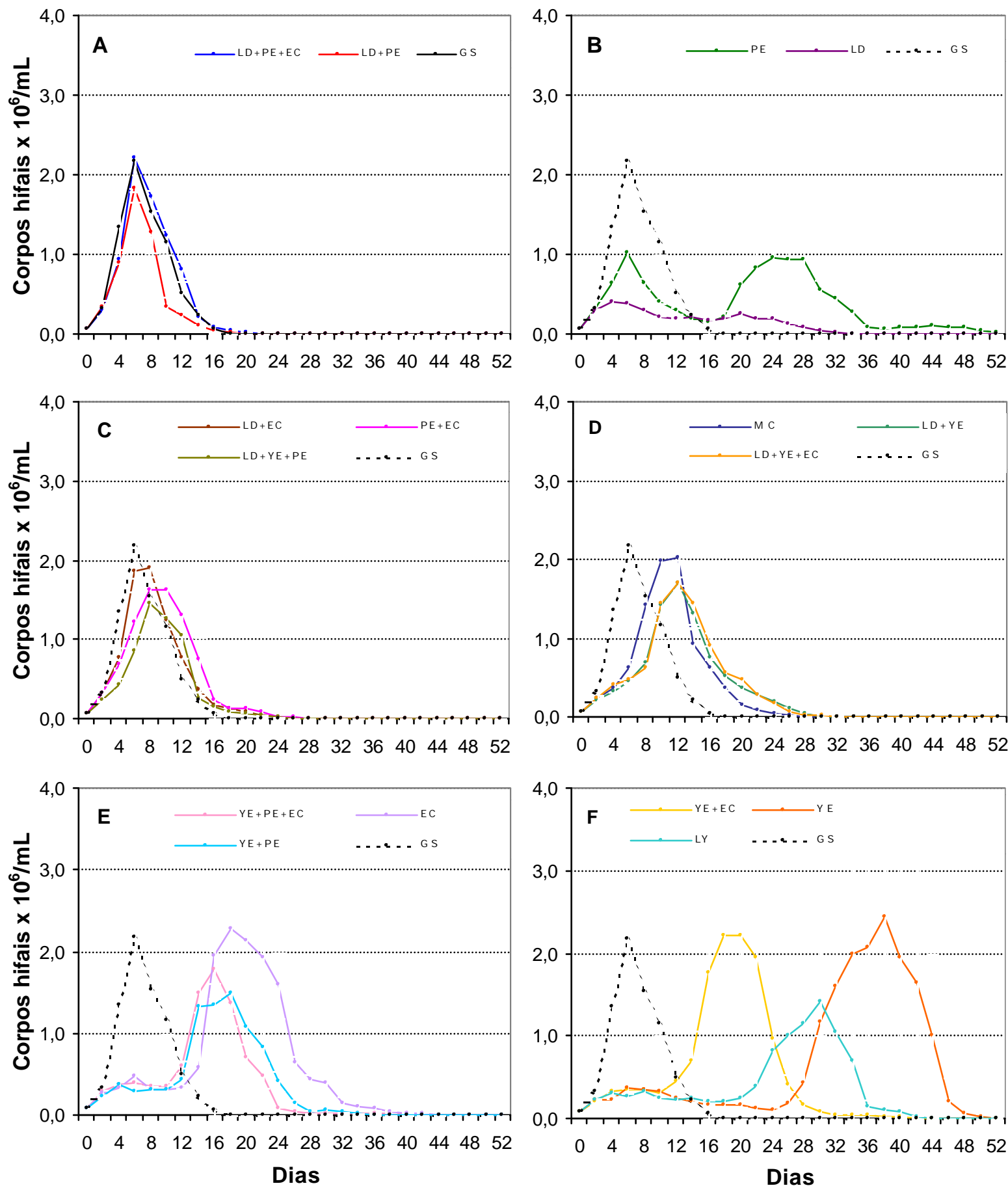

Figura 13 - Crescimento de Neozygites floridana em meios líquidos a base de diferentes combinações dos componentes leite desnatado (LD), extrato de levedura (YE), peptona (PE) e extrato de carne (EC). MC = meio completo; $\mathrm{LY}=$ lactalbumina hidrolisada + yeastolate; GS $=$ Grace's suplementado. Tratamentos (linhas cheias) com picos de crescimento na primeira (A e B), segunda $(\mathrm{C}$ e D) e terceira semana $(\mathrm{E}$ e F). Barras = desvio padrão. 
Batkoa sp. e Furia sp. apresentaram-se menos exigentes quanto as fontes de nitrogênio. Batkoa sp. parece ser mais difícil para desenvolvimento como bioinseticida, com crescimento mais lento e menor produção, enquanto que Furia sp. cresce mais rapidamente, com maior produção nos diferentes meios. As espécies com conidióforo ramificado como Furia sp. são provavelmente mais fáceis de serem produzidas "in vitro" do que aquelas com conidióforo único como Batkoa sp. e N. floridana. Os gêneros Zoophthora e Erynia, os quais possuem conidióforo ramificado, são os dois fungos Entomophthorales mais estudados para o desenvolvimento como bioinseticida a base de micélio seco (Mccabe \& Soper, 1985; Gray \& Markham, 1997; Shah et al., 1998). Por outro lado, Entomophaga, Entomophthora e outros gêneros, os quais possuem conidióforo único, tem sido produzidos em meios mais complexos (Nolan, 1993; Freimoser et al., 2000). O gênero Neozygites têm sido produzido somente em meios para cultura de tecido de inseto, os quais são consideravelmente caros e pouco adequados para um programa de produção massal (Grundschober et al., 1998; Leite et al., 2000).

Efeito de concentrações - Os três fungos também apresentaram respostas diferentes quando avaliados em diferentes concentrações de fontes de nitrogênio. A concentração de $1 \%$ da fonte de nitrogêncio proporcionou maior produção para Batkoa sp., no entanto, 0,5\% apresentou-se como a mais adequada visando a produção, já que é a mais econômica, não diferenciando estatisticamente das concentrações de 0,75 e 1,0\% (F = 6,46; $\mathrm{P}=0,000$ ). Além disso, essa concentração apresentou o menor desvio padrão em relação as duas concentrações maiores (Figuras 14 a 15).

Para Furia sp., a concentração de $2 \%$ proporcionou maior produção, diferindo significativamente dos demais tratamentos $(\mathrm{F}=137,53 ; \mathrm{P}=0,000)$. No entanto, a concentração de $1 \%$ pode ser mais adequada para produção desse patógeno já que proporcionou a segunda maior produção, além de ser mais econômica e ter a margem de segurança da concentração de $2 \%$ antes de causar efeito tóxico, conforme observado na de $3 \%$ (Figura 14). 
Batkoa sp.

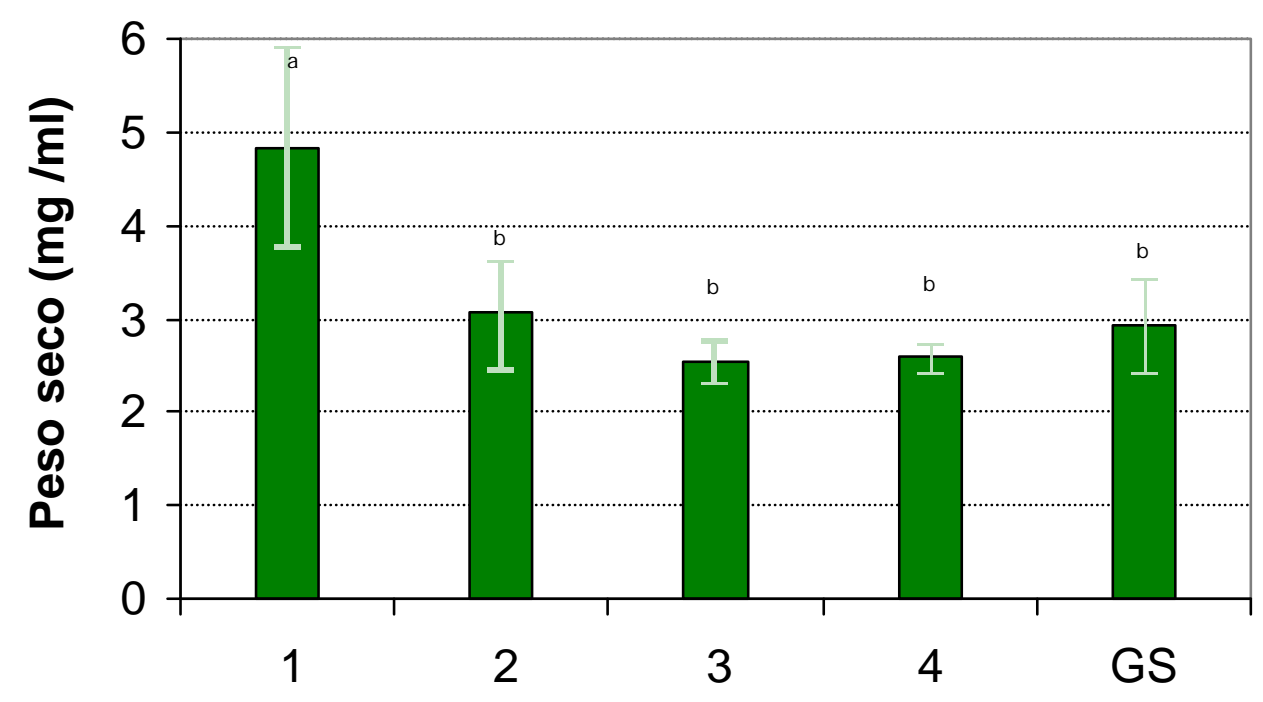

Furia sp.

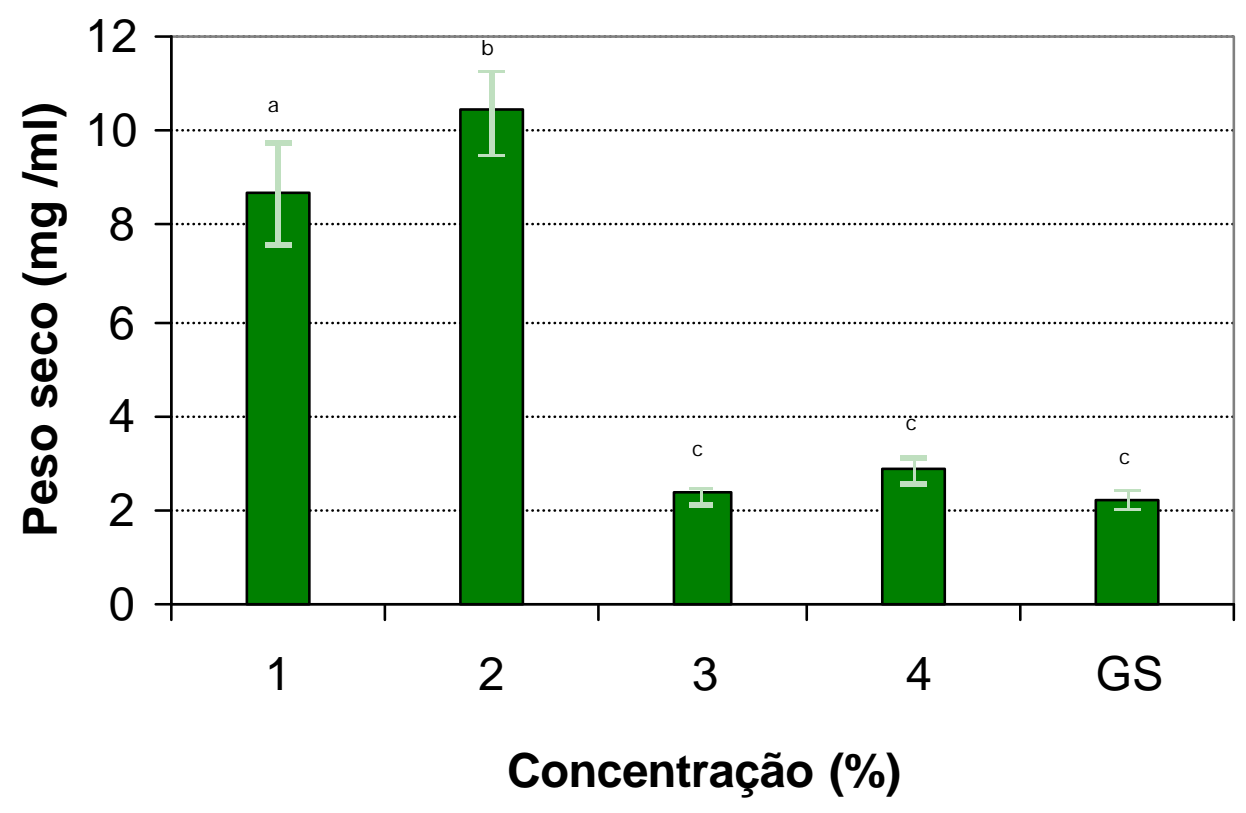

Figura 14 - Produção de Batkoa sp. e Furia sp. em meios líquidos contendo concentrações totais de $1,2,3$ e $4 \%$ de extrato de levedura para o primeiro patógeno, e da mistura em iguais proporções de extrato de levedura, extrato de carne e peptona, para o segundo. GS = Grace's suplementado. Tratamentos com a mesma letra não diferem entre si pelo teste de Tukey, ao nível de 5\% de probabilidade. Barras $=$ desvio padrão. 
Batkoa sp.

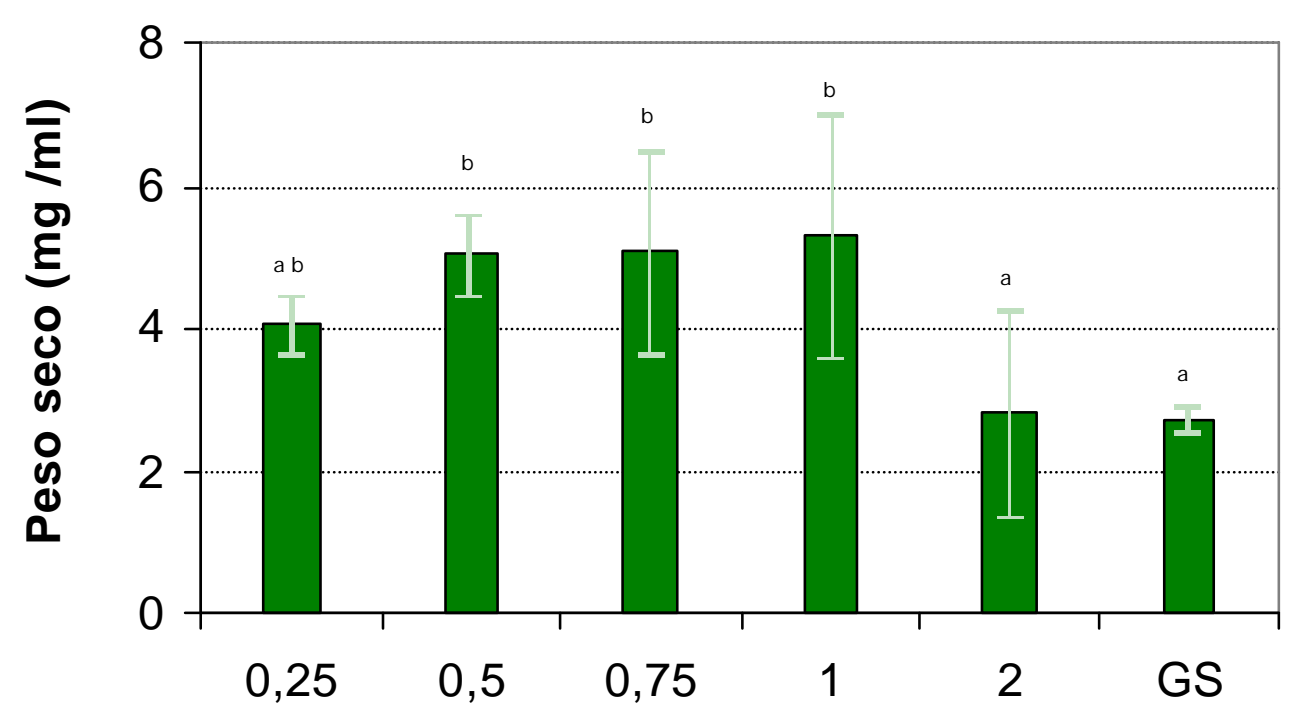

Furia sp.

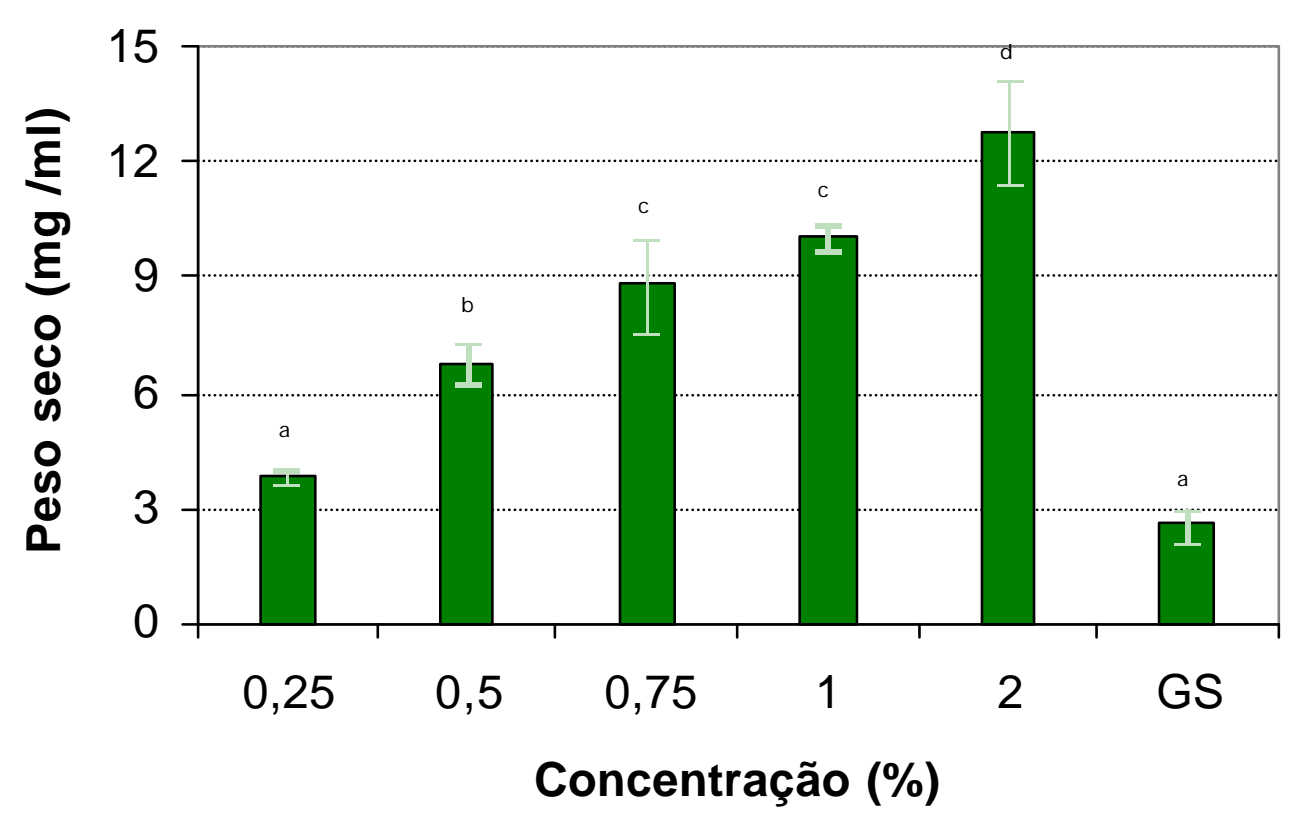

Figura 15 - Produção de Batkoa sp. e Furia sp. em meios líquidos contendo concentrações totais de 0,$25 ; 0,5 ; 0,75 ; 1$ e $2 \%$ de extrato de levedura para o primeiro patógeno, e da mistura em iguais proporções de extrato de levedura, extrato de carne e peptona para o segundo. GS = Grace's suplementado. Tratamentos com a mesma letra não diferem entre si pelo teste de Tukey, ao nível de 5\% de probabilidade. Barras $=$ desvio padrão. 
Nas concentrações acima de $1 \%$ para Batkoa sp. e 2\% para Furia sp., houve uma redução significativa na produção $\left(\mathrm{F}_{\mathrm{Batkoa}}=24,72 ; \mathrm{P}_{\text {Batkoa }}>0,000 ; \mathrm{F}_{\text {furia }}=378,27 ; \mathrm{P}_{\text {Furia }}\right.$ $>0,000)$, com rendimentos até mesmo abaixo daqueles obtidos nos meios com a menor concentração total das fontes de nitrogênio $(0,25 \%)$. Essas concentrações maiores causaram algum efeito tóxico aos fungos (Figura 15).

N. floridana não apresentou inibição de crescimento em função do aumento de concentração das fontes de nitrogênio, com $4 \%$ proporcionando a maior produção, acima de 2 vezes em relação ao meio Grace's suplementado (Figura 16). Para N. floridana, a concentração de 3\% apresentou-se mais adequada visando a produção massal, proporcionando uma produção acima de 2 vezes em relação as menores concentrações e pouco abaixo comparada a maior (4\%), porém com pico de crescimento mais antecipado.

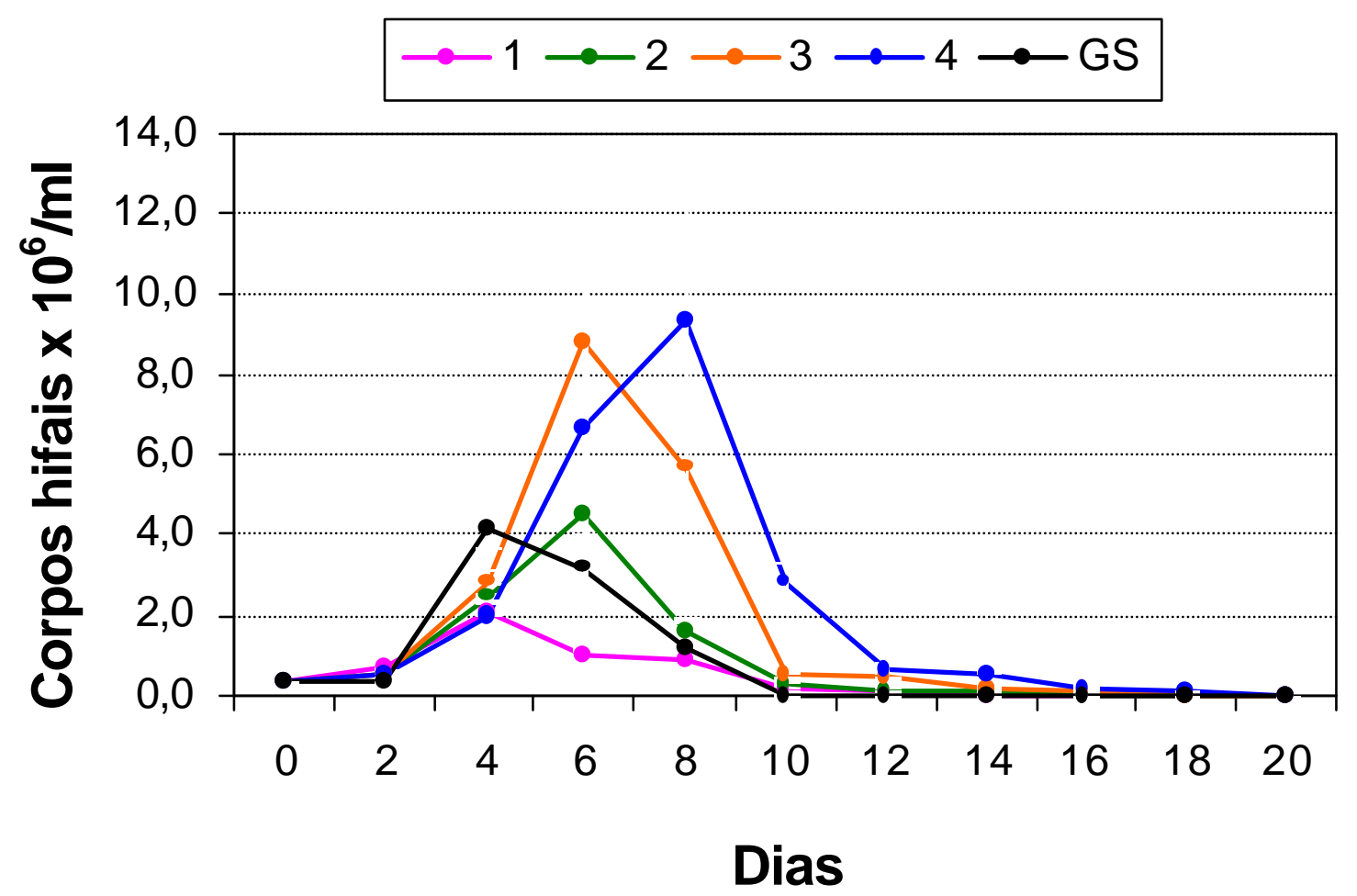

Figura 16 - Produção de Neozygites floridana em meios líquidos contendo concentrações totais de 1, 2, 3 e $4 \%$ da mistura em iguais proporções de extrato de carne, leite desnatado e peptona. GS = Grace's suplementado. Barras = desvio padrão. 
As melhores concentrações de fontes de nitrogênio para Batkoa sp. (0,5 a 1,0\%) e Furia sp. (1,0 e 2,0\%) podem se assemelhar a concentração de aminoácidos nos seus hospedeiros Mahanarva fimbriolata (Fabr., 1787) e Deois schach (Fabr., 1787), respectivamente, uma vez que a concentração de aminoácidos em pulgão é de 1,4\% (Schoffeniels \& Gilles, 1970). As concentrações mais elevadas foram tóxicas a esses fungos devido, provavelmente, ao excesso de amonia liberado pelos patógenos em decorrência da grande quantidade de nitrogênio metabolizado.

Batkoa sp. parece ser mais suscetível a elevadas concentrações de nitrogênio, pois teve crescimento reduzido em concentrações de extrato de levedura acima de $1 \%$ e até mesmo inibido quando, em estudos anteriores, utilizou-se $1 \%$ de proteína hidrolisada de soja, um dos componentes mais ricos em nitrogênio, com teor de até $40 \%$. Isso, provavelmente, explica o fato de leite desnatado e peptona, os quais são ricos em aminoácidos, não aumentarem a produção desse fungo quando adicionados ao meio, conforme observado nesse experimento. O leite desnatado é uma fonte de nitrogênio geralmente utilizada para a produção de Entomophthorales, especialmente em combinação com gema de ovo (Papierok \& Hajek, 1997). Pelo presente estudo, o uso do mesmo pode não ser vantajoso para todas as espécies.

A suscetibilidade de Entomophthorales a diferentes concentrações de fontes de nitrogênio varia provavelmente entre as espécies da Ordem. O fungo Entomophthora thaxteriana também teve aumento gradativo na produção em função do aumento de 1 para 4\% na concentração de extrato de levedura como fonte de nitrogênio (Latgé et al., 1978). Segundo Schoffeniels \& Gilles (1970), a concentração de aminoácidos na hemolinfa dos pulgões depende da espécie do inseto e da planta hospedeira. Assim, a menor suscetibilidade de $N$. floridana às concetrações mais elevadas de nitrogênio sugere que o seu hospedeiro, T. urticae, possa apresentar concentrações mais elevadas de aminoácidos na hemolinfa do que os hospedeiros de Batkoa sp. e Furia sp., que são as cigarrinhas $M$. fimbriolata e D. schach, respectivamente. Isso pode ser enfatizado pelo fato de que o ácaro ataca especialmente plantas leguminosas, com maior teor de nitrogênio, enquanto que as cigarrinhas atacam gramíneas, que possuem menor teor.

Os meios obtidos nesse estudo são simples, econômicos e permitem a produção das três espécies de Entomophthorales, com rendimentos superiores aos obtidos com o meio Grace's suplementado. Os meios podem ser escolhidos considerando-se não somente 
o rendimento na produção desses patógenos, mas também disponibilidade e custo das fontes de nitrogênio. $\mathrm{O}$ extrato de levedura apresentou-se bastante adequado para a produção massal de Batkoa sp., pois é facilmente encontrado em lojas do ramo, sendo vendido a um custo relativamente baixo (U\$ $23.00 / 500 \mathrm{~g}$ ). O custo do litro de meio, considerando a concentração de $0,5 \%$ desse componente e os gastos com outros ingredientes é de aproximadamente U\$ 0.40 .

Para Furia sp., leite desnatado + extrato de levedura + extrato de carne proporcionou maior produção, no entanto, a mistura leite desnatado + extrato de levedura apresenta-se também adequada para a produção em larga escala, pois proporcionou a segunda maior produção sem diferenciar significativamente da primeira mistura, além de permitir maior facilidade no preparo do meio, descartando o componente mais caro, extrato de carne (U\$ $54.50 / 500$ g). O custo do litro de meio, considerando a concentração de $1 \%$ do total das fontes de nitrogênio, seria de U\$ 0.70 para LD+YE+EC e U\$ 0.42 para LD+YE.

Para N. floridana, o meio leite desnatado + peptona + extrato de carne apresentou-se mais adequado, pois proporcionou uma das maiores produções, com o pico de crescimento mais antecipado. O custo do litro de meio, considerando a concentração de $3 \%$ do total das fontes de nitrogênio, é de U\$ 2.02, portanto, muito abaixo do meio Grace's suplementado, o qual é encontrado somente em lojas bastante especializadas, sendo vendido a um custo em torno de U\$ 40.00 o litro.

Assim, o meio de cultura para Batkoa sp. é o mais econômico, o que compensa a menor produção desse fungo /volume de meio comparada com o de Furia sp. No entanto, no calculo de custo do meio de cultura, deve-se considerar também o volume do meio necessário para a produção do fungo, o que será possível somente com base em pesquisas futuras, quando forem determinadas as concentrações desses fungos necessárias para o controle das pragas.

\subsection{Conclusões}

Os ensaios e observações realizadas permitiram concluir que:

1. O extrato de levedura proporciona maior produção de Batkoa sp.; 
2. A concentração de $0,5 \%$ de extrato de levedura é a mais adequada para a produção vegetativa de Batkoa sp. em meio líquido;

3. A combinação de extrato de levedura + extrato de carne + leite desnatado proporciona maior produção de Furia sp.;

4. A combinação de extrato de levedura + leite desnatado proporciona o segundo maior rendimento de Furia sp., sendo mais adequada para a produção do fungo devido ao menor custo;

5. A concentração de $1 \%$ da mistura dessas fontes de nitrogênio é adequada para a produção vegetativa de Furia sp.;

6. A combinação de extrato de levedura + peptona + leite desnatado proporciona a maior produção de N. floridana;

7. A concentração de $3 \%$ da mistura dessas fontes de nitrogênio é a mais adequada para a produção vegetativa de $N$. floridana. 


\section{EFEITO DE DIFERENTES SAIS NA PRODUÇÃO DE ENTOMOPHTHORALES}

Resumo

Fungos da Ordem Entomophthorales têm sido encontrados causando epizootias em populações de insetos e ácaros em todo o mundo, o que justifica estudos procurando desenvolver esses agentes como bioinseticidas e bioacaricidas. Procurando desenvolver meios simples e baratos para a produção de Entomophthorales, muitos estudos têm avaliado fontes de carbono e nitrogênio, porém poucos estudam a ação de sais, considerados como importantes elementos na nutrição de fungos. Esses minerais têm sido utilizados em conjunto, o que dificulta bastante o preparo do meio uma vez que a mistura de sais pode acarretar a precipitação dos mesmos, principalmente quando submetidos a altas temperaturas em autoclave. Em função disso, o objetivo da pesquisa foi avaliar separadamente os 6 tipos de sais usados no meio para cultura de tecido de insetos, Grace's suplementado, na produção em meio líquido de micélio ou corpos hifais de Batkoa sp., Furia sp. e Neozygites floridana. A mistura dos sais $\mathrm{CaCh}_{2} .2 \mathrm{H}_{2} \mathrm{O}(0,06 \%), \mathrm{KCl}(0,28 \%)$, $\mathrm{MgCh} .6 \mathrm{H}_{2} \mathrm{O}(0,16 \%), \mathrm{MgSO}_{4} \cdot 7 \mathrm{H}_{2} \mathrm{O}(0,2 \%), \mathrm{NaHCO}_{3}(0,03 \%)$ e $\mathrm{NaH}_{2} \mathrm{PO}_{4} \cdot \mathrm{H}_{2} \mathrm{O}(0,1 \%)$ proporciona maior produção dos fungos do que os sais utilizados isoladamente na cocentração de $0,83 \%$. No entanto, o sulfato de magnésio $\left(\mathrm{MgSO}_{4}\right)$ pode ser utilizado como único sal, na concentração de $0,83 \%$, visando a produção de Batkoa sp., Furia sp. e $N$. floridana, não diferenciando significativamente da mistura dos sais. 


\section{Summary}

\section{Effects of salts on the growth of Entomophthorales fungi}

Entomophthorales fungi have been found causing epizootics in insect and mite populations, which justifies studies to develop these agents as biopesticides and bioacaricides. Published efforts to develop simple and inexpensive media for the production of Entomophthorales have evaluated sources of carbon and nitrogen, but few have studied the action of salts, which are known important elements for fungal nourishment. These minerals have been used as mixtures, which can make difficulties in medium preparation since the salts may interact to cause their precipitation, especially when exposed to high (autoclave) temperatures. The research reported here aimed at evaluating the effect of 6 salts $\left(\mathrm{CaCl}_{2} \cdot 2 \mathrm{H}_{2} \mathrm{O}, \mathrm{KCl}, \mathrm{MgCh}_{2} \cdot 6 \mathrm{H}_{2} \mathrm{O}, \mathrm{NaH}_{2} \mathrm{PO}_{4} \cdot \mathrm{H}_{2} \mathrm{O}, \mathrm{MgSO}_{4} \cdot 7 \mathrm{H}_{2} \mathrm{O}\right.$ and $\left.\mathrm{NaHCO}_{3}\right)$ used in an insect cell culture medium, Grace's supplemented, on the production in liquid medium of mycelium or hyphal bodies of Batkoa sp. and Furia sp., pathogens of the spittlebugs pests of pasture and sugar-cane in Brazil, and Neozygites floridana, pathogenic to several mites. The mixture of salts afforded higher vegetative growth of the three fungi than did the salts evaluated individually at $0.83 \%$ concentration. Meanwhile, $\mathrm{MgSO}_{4}$ can be used as the sole salt for production of Batkoa sp., Furia sp. and N. floridana without significant differences from the salts mixture. 


\subsection{Introdução}

Fungos da Ordem Entomophthorales têm sido encontrados causando epizootias em populações de insetos e ácaros em todo o mundo, o que justifica estudos procurando desenvolver esses agentes como bioinseticidas e bioacaricidas. Dentre esses fungos incluem-se as espécies Batkoa sp. e Furia sp., patógenos das cigarrinhas das pastagens e cana-de-açúcar, pertencentes aos gêneros Mahanarva e Deois, respectivamente, e Neozygites floridana (Weiser \& Muma) Remaudière \& Keller, patógeno de ácaros como Tetranychus urticae Koch (Alvares et al. 1991) (Leite et al., 2000).

Estudos sobre a produção desses entomopatógenos em meios artificiais têm avançado bastante. O meio Grace's para cultura de tecido de insetos foi, inicialmente, utilizado para isolamento de espécies de Entomophthora (Welton \& Tyrrell, 1975). Esse meio, suplementado com outros componentes, possibilita o cultivo de espécies consideradas ainda na década de 80 parasitos obrigatórios (Latgé, 1982) como $N$. parvispora e N. floridana, patógenos de Thrips tabaci e $T$. urticae, respectivamente (Grundschober et al., 1998; Leite et al., 2000).

Procurando desenvolver meios simples e baratos para a produção de Entomophthorales, muitos estudos têm avaliado fontes de carbono e nitrogênio, porém poucos estudam a ação de sais, considerados como importantes elementos na nutrição de fungos. Esses minerais têm sido utilizados em conjunto (Wolf, 1951; Latgé \& Samglier, 1985), o que dificulta bastante o preparo do meio uma vez que a mistura de sais pode acarretar a precipitação dos mesmos, principalmente quando submetidos a altas temperaturas em autoclave. Em função disso, o objetivo da pesquisa foi avaliar separadamente os 6 tipos de sais usados no meio para cultura de tecido de insetos, Grace's suplementado, na produção em meio líquido de Batkoa sp., Furia sp. e N. floridana.

\subsection{Material e Métodos}

Os sais avaliados para a produção de Batkoa sp. Furia sp. e N. floridana foram $\mathrm{CaCl}_{2} .2 \mathrm{H}_{2} \mathrm{O}, \mathrm{KCl}, \mathrm{MgCh} \cdot 6 \mathrm{H}_{2} \mathrm{O}, \mathrm{NaH}_{2} \mathrm{PO}_{4} \cdot \mathrm{H}_{2} \mathrm{O}, \quad \mathrm{MgSO}_{4} .7 \mathrm{H}_{2} \mathrm{O}$ e $\mathrm{NaHCO}_{3}$. Foram considerados 9 tratamentos, representados pelo meio Grace's suplementado com lactalbumina hidrolisada mais yeastolate $\left(\mathrm{HyQ}^{\circledR}\right.$ TNM-FH, \#SH30280.02); meio básico 
(sem sais); meio básico contendo a mistura dos sais e meio básico contendo os 6 sais individualizados.

O meio básico foi preparado com 2,66\% de glucose (dextrose), utilizando-se diversas fontes de nitrogênio em diferentes combinações e concentrações para cada fungo, as quais foram selecionadas em estudos anteriores. Assim, para Batkoa sp. foi usado extrato de levedura (0,5\%); para Furia sp., a mistura de extrato de levedura $(0,33 \%)+$ extrato de carne $(0,33 \%)+$ leite desnatado $(0,33 \%)$; e para $N$. floridana, a mistura de extrato de carne $(1 \%)+$ leite desnatado $(1 \%)+$ peptona $(1 \%)$.

Para o tratamento meio básico + mistura de sais, os minerais foram utilizados nas mesmas concentrações empregadas no meio Grace's suplementado: 0,06\% para $\mathrm{CaCl}_{2} .2 \mathrm{H}_{2} \mathrm{O} ; 0,28 \%$ para $\mathrm{KCl} ; 0,16 \%$ para $\mathrm{MgCh}_{2} .6 \mathrm{H}_{2} \mathrm{O} ; 0,2 \%$ para $\mathrm{MgSO}_{4} .7 \mathrm{H}_{2} \mathrm{O} ; 0,03 \%$ para $\mathrm{NaHCO}_{3}$ e $0,1 \%$ para $\mathrm{NaH}_{2} \mathrm{PO}_{4} \cdot \mathrm{H}_{2} \mathrm{O}$. Para os tratamentos meio básico + sais individualizados, os minerais foram utilizados na concentração de $0,83 \%$, equivalente a concentração total da mistura desses minerais no meio Grace's suplementado.

No preparo dos meios, o açúcar e as fontes de nitrogênico foram autoclavados em soluções separadas, contendo o dobro de suas concentrações, antes de serem misturados em partes iguais. A autoclavagem desses componentes em uma mesma solução resulta em efeitos deletérios a $N$. floridana. Os sais foram adicionados nos meios após a autoclavagem dos mesmos, utilizando-se soluções matrizes separadas para cada sal, nas concentrações de $50 \%$ para $\mathrm{CaCl}_{2} .2 \mathrm{H}_{2} \mathrm{O}$ e $\mathrm{KCl}$, e $100 \%$ para $\mathrm{MgCl}_{2} \cdot 6 \mathrm{H}_{2} \mathrm{O}, \mathrm{NaH}_{2} \mathrm{PO}_{4} \cdot \mathrm{H}_{2} \mathrm{O}, \mathrm{MgSO}_{4} .7 \mathrm{H}_{2} \mathrm{O}$ e $\mathrm{NaHCO}_{3}$.

$\mathrm{O}$ pH dos meios foi ajustado para 6,2, utilizando-se um peagâmetro e soluções esterilizadas de $\mathrm{HCl}(0,1 \%)$ e $\mathrm{NaOH}(10 \%)$. Posteriormente, os meios foram avaliados quanto a pressão osmótica, utilizando-se um osmômetro.

Para os fungos Batkoa sp. e Furia sp. foram utilizadas 6 repetições por tratamento, sendo cada repetição representada por um tubo plástico $(2,8$ x $11,8 \mathrm{~cm})$ de 50 $\mathrm{mL}$ contendo $8 \mathrm{~mL}$ do meio de cultura. O fungo utilizado para inoculação dos tubos foi obtido de uma colônia desenvolvida em meio de cultura sólido, constituído de extrato de levedura (2\%), dextrose $(2 \%)$ e ágar $(1,5 \%)$. Cada tubo foi inoculado com um pedaço de 0,3 x 0,3 cm do micélio crescido na superfície do meio por 5 dias para Batkoa sp. e 3 dias para Furia sp. Após a inoculação, os tubos foram tampados e acondicionados em um agitador orbital, ajustado para $200 \mathrm{rpm}$, na temperatura de $23^{\circ} \mathrm{C}$ e fotofase de 14 horas. As 
tampas foram mantidas levemente desatarraxadas, visando permitir a troca de gases entre o interior do tubo e o ambiente.

Após um período de 7 dias, procedeu-se a avaliação quanto a produção de massa seca dos patógenos nos diferentes meios de cultura. Para isso, o fungo foi filtrado em papel de filtro de $45 \mathrm{~mm}$ de diâmetro com o auxílio de uma bomba de vácuo, descartandose o meio de cultura. Os papéis de filtro, antes de serem utilizados, foram mantidos por 24 horas a $70^{\circ} \mathrm{C}$ e, em seguida, pesados. Após a filtragem, os papéis com o fungo foram submetidos ao mesmo procedimento.

Para o fungo N. floridana foram utilizadas 5 repetições por tratamento, sendo cada repetição representada por um tubo plástico $(1,5 \times 9,5 \mathrm{~cm})$ de $8 \mathrm{~mL}$ contendo $2 \mathrm{~mL}$ do meio de cultura. Cada tubo foi inoculado com $0,1 \mathrm{~mL}$ de uma suspensão de corpos hifais de N. floridana, obtida de uma colônia desenvolvida no meio líquido Grace’s suplementado. Após a inoculação, os tubos foram tampados, agitados em vortex e acondicionados em um agitador orbital, ajustado para $200 \mathrm{rpm}$, na temperatura de $23^{\circ} \mathrm{C}$ e fotofase de 14 horas. Os tubos foram posicionados com inclinação de $45^{\circ}$ no agitador, sendo suas tampas mantidas levemente desatarraxadas.

As avaliações foram feitas a cada 2 dias, durante 26 dias, avaliando-se a concentração de corpos hifais/mL para cada tubo. Na instalação do experimento, também foram inoculados outros 5 tubos, contendo $2 \mathrm{~mL}$ de água destilada por tubo, com o objetivo de serem utilizados apenas para determinar a concentração inicial de corpos hifais. A concentração do fungo foi determinada com o auxílio de uma câmara de Newbauer e um microscópio óptico com contraste de fase, utilizando-se aumento de $100 \mathrm{X}$. Para isso os tubos foram previamente agitados em vortex.

Os experimentos foram submetidos a análise de variância e as médias comparadas pelo teste de Tukey $(\mathrm{P}<0,05)$.

\subsection{Resultados e Discussão}

A combinação de todos os sais (SA) proporcionou maior produção para Batkoa sp. e Furia sp., embora não tenha diferenciado significativamente dos tratamentos $\mathrm{MgSO}_{4}$ e $\mathrm{KCl}$ para o primeiro patógeno, e $\mathrm{MgCl}, \mathrm{NaH}_{2} \mathrm{PO}_{4}$ e $\mathrm{MgSO}_{4}$ para o segundo. Os meios contendo $\mathrm{NaHCO}_{3}$ e Grace's suplementado proporcionaram as menores produções para 
Batkoa sp. e Furia sp., respectivamente, com diferenças significativas comparados aos meios básicos (Figura 16).

Para N. floridana (Figura 17), $\mathrm{KCl}$ resultou na maior produção dentre os tratamentos, sendo que $\mathrm{MgCh}, \mathrm{NaHCO}_{3}, \mathrm{SA}$ e $\mathrm{MgSO}_{4}$ proporcionaram produção pouco abaixo, porém, com picos de crescimento do patógeno antecipados em 4 dias comparados com $\mathrm{KCl}$.

Os meios contendo $\mathrm{KCl}$ como único sal, preparados para os diferentes fungos, apresentaram as maiores pressões osmóticas, (meio para Batkoa sp.: 363 mOsm; para Furia sp.: 376 mOsm; e para $N$. floridana: $423 \mathrm{mOsm}$ ), enquanto que os meios não adicionados de sais (básicos) apresentaram as menores pressões osmóticas (Batkoa sp.: 210 mOsm; Furia sp.: 229 mOsm; e N. floridana: 265 mOsm) (Tabela 11).

Em geral, fica evidente a contribuição da mistura de sais (SA) para a produção desses 3 patógenos, proporcionando a maior produção para Batkoa sp. e Furia sp., e a terceira maior para $N$. floridana.

$\mathrm{MgSO}_{4}, \mathrm{MgCl}_{2}$ e $\mathrm{KCl}$ destacaram-se dentre os sais avaliados isoladamente, visto que esses minerais proporcionaram as maiores produções para cada patógeno, com exceção do último sal para Furia sp. $\mathrm{MgSO}_{4}$ proporcionou o 4 maior rendimento para $N$. floridana, mas permitiu a produção de corpos hifais mais uniformes e com maior semelhança a aqueles obtidos no hospedeiro natural (Figura 18). Ambos $\mathrm{Mg}$ e $\mathrm{SO}_{4}$ foram importantes na produção de Entomophthorales. Magnésio é requerido por todos os fungos, tendo função de regulador do metabolismo, pois estabiliza ATP, RNA e enzimas, pdendo ainda afetar as fibras do fuso cromático (Garraway \& Evans, 1984). Esse elemento, fornecido por $\mathrm{MgSO}_{4} .7 \mathrm{H}_{2} \mathrm{O}$, estimulou o crescimento de C. obscurus, proporcionando a maior produção de azigósporos em relação a 7 outros elementos $(\mathrm{Ca}$, fornecido por $\mathrm{CaCl}_{2} .2 \mathrm{H}_{2} \mathrm{O} ; \mathrm{Fe}$, por $\mathrm{FeSO}_{4} .7 \mathrm{H}_{2} \mathrm{O} ; \mathrm{Cu}$, por $\mathrm{CuSO}_{4} .5 \mathrm{H}_{2} \mathrm{O} ; \mathrm{Zn}$, por $\mathrm{ZnSO}_{4} . .7 \mathrm{H}_{2} \mathrm{O}$; Co, por $\mathrm{CoCh}_{2} .7 \mathrm{H}_{2} \mathrm{O}$; $\mathrm{Mo}$, por $\mathrm{Mo}\left(\mathrm{NH}_{4}\right)_{6} \mathrm{Mo}_{7} \mathrm{O}_{24} .4 \mathrm{H}_{2} \mathrm{O}$; e $\mathrm{Mn}$, por $\mathrm{MnCl}_{2} .5 \mathrm{H}_{2} \mathrm{O}$ ), podendo ser utilizado em concentrações de 0,2 a 12,8g/l (Latgé \& Sanglier, 1985). 


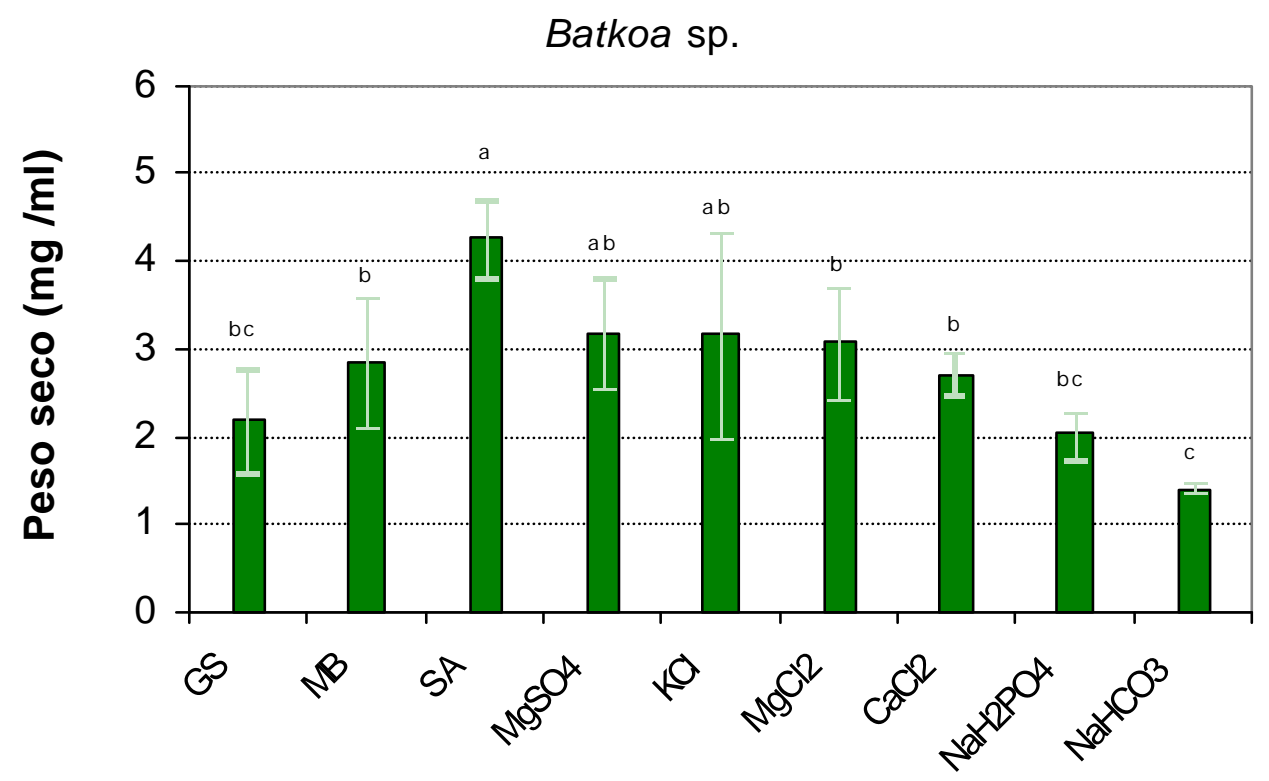

Furia sp.

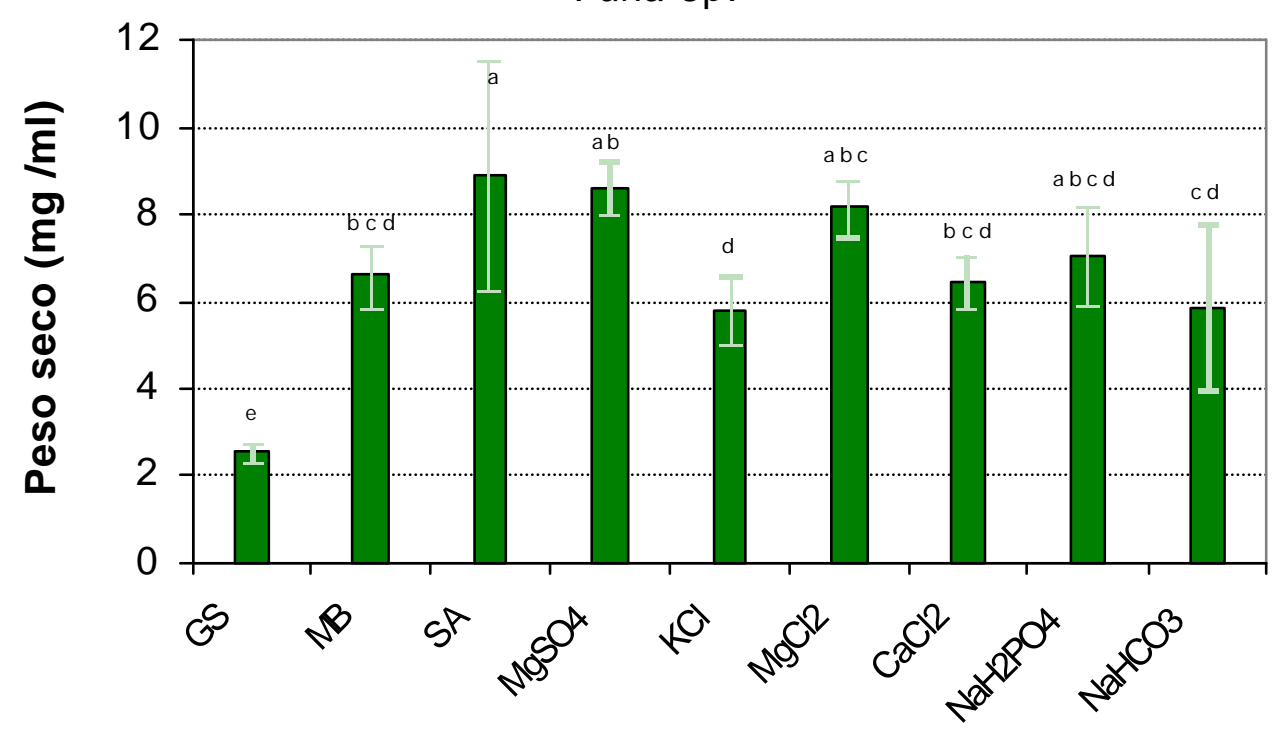

Tratamento

Figura 16 - Produção de Batkoa sp. e Furia sp. em meios líquidos contendo $\mathrm{CaCh}_{2} \cdot 2 \mathrm{H}_{2} \mathrm{O}$, $\mathrm{KCl}, \mathrm{MgCl}_{2} \cdot 6 \mathrm{H}_{2} \mathrm{O}, \mathrm{NaH}_{2} \mathrm{PO}_{4} \cdot \mathrm{H}_{2} \mathrm{O}, \mathrm{MgSO}_{4} \cdot 7 \mathrm{H}_{2} \mathrm{O}$ e $\mathrm{NaHCO}_{3} . \mathrm{MB}=$ meio básico (sem sais). $\mathrm{SA}=$ meio contendo a mistura de todos os sais. $\mathrm{GS}=$ meio Grace's suplementado. Tratamentos com a mesma letra não diferem entre si pelo teste de Tukey, ao nível de 5\% de probabilidade. Barras = desvio padrão. 

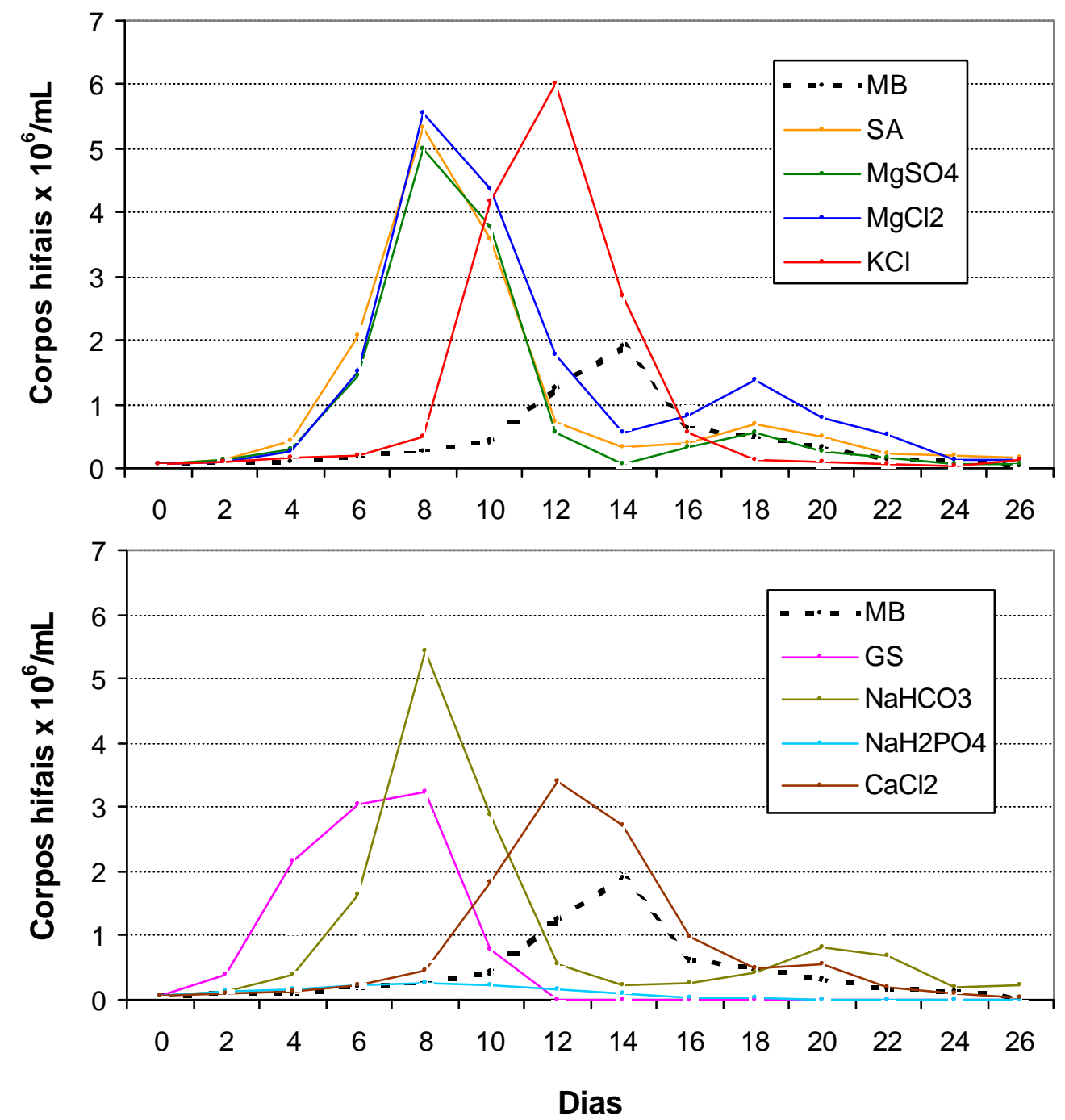

Figura 17 - Crescimento de Neozygites floridana em meios líquidos contendo $\mathrm{CaCh}_{2} \cdot 2 \mathrm{H}_{2} \mathrm{O}$, $\mathrm{KCl}, \mathrm{MgCl} \cdot 6 \mathrm{H}_{2} \mathrm{O}, \mathrm{NaH}_{2} \mathrm{PO}_{4} \cdot \mathrm{H}_{2} \mathrm{O}, \mathrm{MgSO}_{4} \cdot 7 \mathrm{H}_{2} \mathrm{O}$ e $\mathrm{NaHCO}_{3} . \mathrm{MB}=$ meio básico (sem sais). $\mathrm{SA}=$ meio contendo a mistura de todos os sais. $\mathrm{GS}=$ meio Grace's suplementado. Barras = desvio padrão. 
Tabela 11. Pressão osmótica (mOsm) de meios líquidos contendo 6 diferentes sais, para três diferentes fungos. $\mathrm{MB}=$ meio básico (sem sais). $\mathrm{SA}=$ meio contendo a mistura de todos os sais. GS = meio Grace's suplementado.

\begin{tabular}{|c|c|c|c|}
\hline \multirow[t]{2}{*}{ Tratamento } & \multicolumn{3}{|c|}{ Fungo } \\
\hline & Batkoa sp. * & Furia sp. * & Neozygites floridana \\
\hline $\mathrm{KCl}$ & $363 \pm 5,2$ & $376 \pm 2,0$ & $423 \pm 6,4$ \\
\hline $\mathrm{NaHCO}_{3}$ & $344 \pm 2,9$ & $354 \pm 2,9$ & $396 \pm 6,9$ \\
\hline SA & $342 \pm 2,7$ & $341 \pm 2,7$ & $351 \pm 3,3$ \\
\hline $\mathrm{CaCl}_{2} \cdot 2 \mathrm{H}_{2} \mathrm{O}$ & $301 \pm 7,6$ & $303 \pm 1,5$ & $341 \pm 5,7$ \\
\hline GS & $295 \pm 1,4$ & $307 \pm 1,4$ & $337 \pm 8,4$ \\
\hline $\mathrm{NaH}_{2} \mathrm{PO}_{4} \cdot \mathrm{H}_{2} \mathrm{O}$ & $291 \pm 4,0$ & $310 \pm 3,3$ & $344 \pm 2,6$ \\
\hline $\mathrm{MgCh}_{2} \cdot 6 \mathrm{H}_{2} \mathrm{O}$ & $280 \pm 1,9$ & $292 \pm 2,5$ & $332 \pm 2,2$ \\
\hline $\mathrm{MgSO}_{4} .7 \mathrm{H}_{2} \mathrm{O}$ & $237 \pm 2,3$ & $250 \pm 4,0$ & $294 \pm 3,6$ \\
\hline MB & $210 \pm 1,9$ & $229 \pm 7,4$ & $265 \pm 3,6$ \\
\hline
\end{tabular}

* Pressão osmótica \pm desvio padrão 


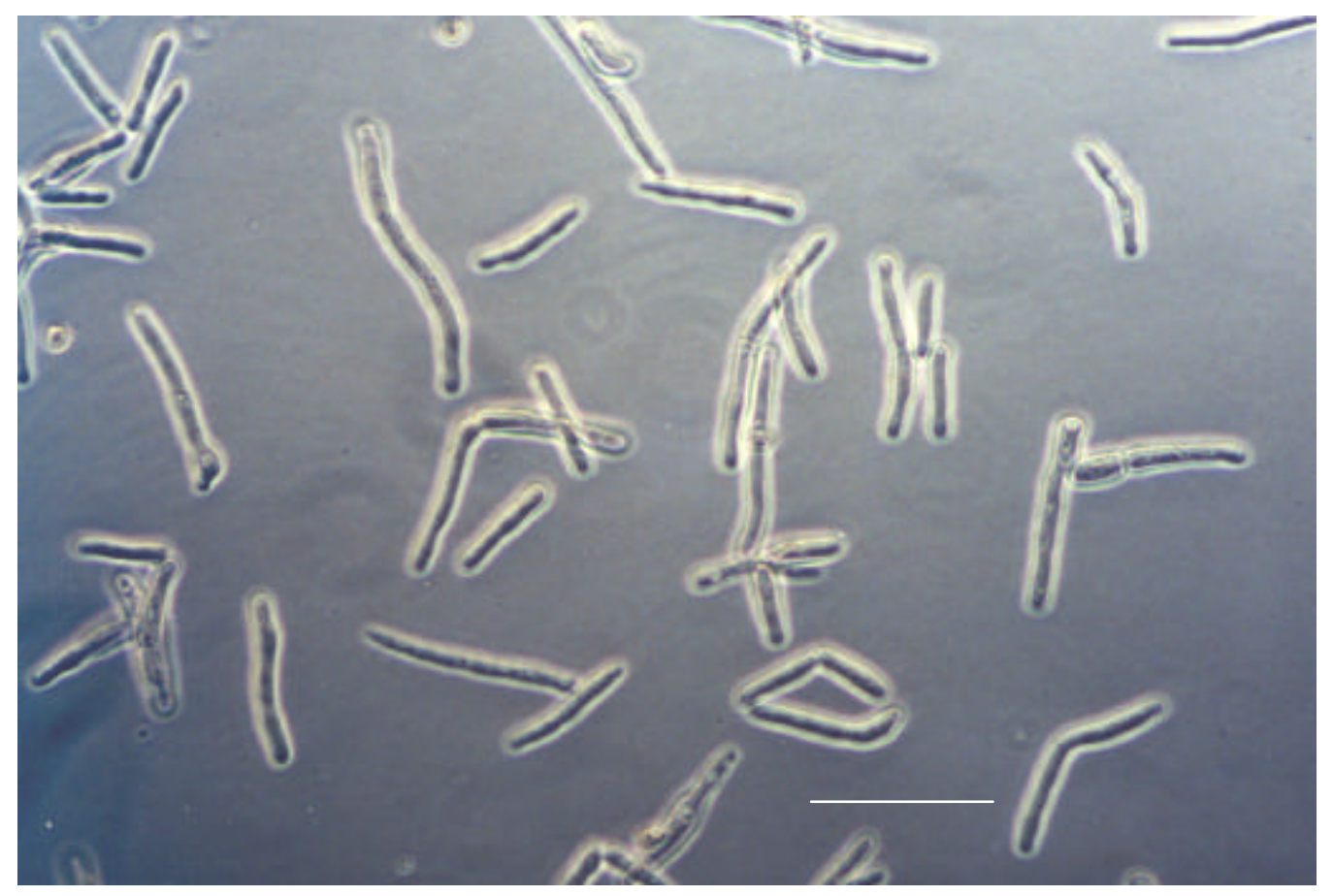

Figura 18 - Corpos hifais de Neozygites floridana produzidos em meio líquido contendo $\mathrm{MgSO}_{4}$ como único sal. Barra $=52 \mu \mathrm{m}$.

O enxofre é necessário por ser um elemento componente de proteínas, vitaminas e metabólitos. Os aminoácidos cisteina e metionina possuem enxofre, com o grupo livre sulfudril do primeiro aminoácido tendo importante função de estabilizar a estrutura da proteína. O enxofre é também componente das coenzimas tiamina, biotina, ácido lipoico e coenzima A. Algumas enzimas possuem complexos de ferro e enxofre nos lados ativos. Sulfato $\left(\mathrm{SO}_{4}{ }^{2-}\right)$ é a forma inorgânica de enxofre mais comumente utilizada pelos fungos. Após absorvido, o sulfato é rapidamente convertido em moléculas orgânicas e, então, em proteínas (Garraway \& Evans, 1984). Os enxofres fornecidos pelo aminoácido metionina e sal $\mathrm{MgSO}_{4} .7 \mathrm{H}_{2} \mathrm{O}$ na concentração de $0,47 \mathrm{~g} / \mathrm{l}$ proporcionaram um incremento na produção de Conidiobolus obscurus, com o enxofre orgânico superando significativamente o mineral (Latgé \& Sanglier, 1985).

$\mathrm{O}$ enxofre elementar $\left(\mathrm{S}_{8}\right)$ tem sido encontrado em diversos grupos de fungos, geralmente em maiores concentrações em estruturas dormentes como esporos, clamidósporos e esclerócios. Esse elemento aceita elétrons geralmente a partir do meio da 
cadeia transportadora, contribuindo para uma baixa taxa de respiração e, consequientemente, prolongar a dormência dessas estruturas (Pezet \& Pont 1975; Pezet \& Pont 1977). O enxofre orgânico (metionina) e mineral $\left(\mathrm{MgSO}_{4} \cdot 7 \mathrm{H}_{2} \mathrm{O}\right)$ aumentaram significativamente, a produção de azigósporos de $C$. obscurus quando usados nas concentrações de 0,47 e 2,85g /l, respectivamente (Latgé \& Sanglier, 1985).

$\mathrm{O} \mathrm{MgCh}_{2}$ proporcionou a segunda maior produção para cada patógeno, dentre os sais avaliados isoladamente. Isso ressalta a importância do magnésio como elemento necessário para a produção desses agentes. Beauvais \& Latgé (1988) constataram também que $\mathrm{Cl}$ é um importante elemento para a produção de Entomophaga aulicae na forma de protoplastos, desenvolvendo um meio contendo apenas $\mathrm{NaCl}$ como sal. Verificaram ainda que o rendimento obtido com esse sal não diferenciou daqueles obtidos com $\mathrm{KCl}$ e $\mathrm{MgCh}$.

As maiores pressões osmóticas obtidas no experimento estiveram mais próximas daquela determinada para a hemolinfa da larva de ultimo instar de Galleria mellonella, de 400 mOsm (Lunau et al., 1993). No entanto, a pressão osmótica parece não estar relacionada à produção dos fungos, pois se obteve altas produções tanto com os meios adicionados de $\mathrm{KCl}$ (exceto para Furia sp.), que apresentaram as maiores pressões osmóticas (363 a 423 mOsm), como com aqueles adicionados de $\mathrm{MgSO}_{4}$ e $\mathrm{MgCh}$, que apresentaram as menores pressões (237 a 294 mOsm e 280 a 332 mOsm, respectivamente). Beauvais \& Latgé (1988) mencionaram que a pressão osmótica não é importante para muitos fungos entomopatogênicos, podendo a espécie de Entomophthorales E. aulicae crescer em meios com pressão osmótica de até 580 mOsm. A pressão osmótica de 129 mOsm afetou drasticamente o crescimento de N. floridana (Leite et al., 2000), sugerindo existir um valor mínimo favorável para o crescimento desse fungo.

$\mathrm{NaHCO}_{3}, \mathrm{NaH}_{2} \mathrm{PO}_{4}$ e $\mathrm{CaCl}$ não se destacaram na produção desses fungos, exceto $\mathrm{NaHCO}_{3}$ para $N$. floridana. Os dois primeiros sais têm sido utilizados como tampão no preparo de meios. Essa função foi observada nitidamente no preparo dos meios, tendo $\mathrm{NaHCO}_{3}$ elevado o pH e $\mathrm{NaH}_{2} \mathrm{PO}_{4}$ reduzido, estabilizando-o em 6,2 quando misturados na proporção usada para o meio Grace's suplementado. Portanto, todos os sais podem apresentar uma função específica e contribuir para o crescimento desses fungos quando utilizados em conjunto nas proporções usadas para o meio Grace's suplementado, o que é enfatizado pela maior produção de Batkoa sp. e Furia sp. no meio básico adicionado desses sais. No entanto, quando se visa uma produção contínua e em larga escala desses fungos, o 
preparo de meios contendo a combinação de todos os sais torna-se mais difícil pelo fato de que os sais necessitam ser autoclavados separadamente para evitar precipitação. Para a produção industrial desses agentes, sugere-se utilizar apenas um sal tendo em vista facilitar o preparo do meio, além de reduzir o custo de produção. Assim, $\mathrm{MgSO}_{4}$ apresenta-se como forte candidato a ser utilizado como único sal no preparo de meios para Entomophthorales. Esse sal possibilita produções superiores àquelas obtidas no meio básico e Grace's suplementado, sem diferenciarem significativamente daquelas obtidas no meio básico mais a combinação de sais. Os meios desenvolvidos nesse estudo são bastante simples e relativamente de baixo custo, especialmente para $N$. floridana, o qual era anteriormente produzido apenas no meio de cultura já pronto, Grace's suplementado, de elevado custo e composição complexa.

\subsection{Conclusões}

Os ensaios e observações realizadas permitiram concluir que:

1. A mistura dos sais $\mathrm{CaCh}_{2} \cdot 2 \mathrm{H}_{2} \mathrm{O}(0,06 \%), \mathrm{KCl}(0,28 \%), \mathrm{MgCh}_{2} \cdot 6 \mathrm{H}_{2} \mathrm{O} \quad(0,16 \%)$, $\mathrm{MgSO}_{4} \cdot 7 \mathrm{H}_{2} \mathrm{O}(0,2 \%), \mathrm{NaHCO}_{3}(0,03 \%)$ e $\mathrm{NaH}_{2} \mathrm{PO}_{4} \cdot \mathrm{H}_{2} \mathrm{O}(0,1 \%)$ proporciona maior produção dos fungos do que os sais avaliados isoladamente na concentração de $0,83 \%$.

2. O sulfato de magnésio $\left(\mathrm{MgSO}_{4}\right)$ pode ser utilizado como único sal, na concentração de 0,83\%, visando a produção de Batkoa sp., Furia sp. e N. floridana. 


\section{PRESERVAÇÃO DE MICÉLIO DE Batkoa sp. e Furia sp. (ENTOMOPHTHORALES) EM COMBINAÇÃO COM DESSECANTES E REDUTORES DE OXIGÊNIO}

\section{Resumo}

A formulação de Entomophthorales é a etapa mais difícil no seu desenvolvimento como biopesticidas. Isso tem dificultado a avaliação da potência biológica de Batkoa sp. e Furia sp. no controle dos cercopídeos Mahanarva fimbriolata e Deois schach, pragas da cana-de-açúcar e das pastagens. Uma técnica de produção de micélio seco de Entomophthorales foi desenvolvida para permitir o uso desses fungos, no entanto, com resultados pouco satisfatórios quanto a preservação dos patógenos. Devido a esssas dificuldades, realizou-se esse estudo visando avaliar o efeito da combinação de dessecantes (sílica e glicerol) com redutores de oxigênio (vácuo e Ageless® ZPT-200) na preservação de micélio seco dos fungos Batkoa sp. e Furia sp. A combinação de sílica + Ageless® prolonga a sobrevivência desses dois fungos formulados como micélio seco até 90 dias, armazenados a $3^{\circ} \mathrm{C}$ e $23^{\circ} \mathrm{C}$. O uso de vácuo como redutor de oxigênio não prolonga a sobrevivência desses fungos, mesmo em associação com dessecantes. A temperatura de $3^{\circ} \mathrm{C}$ provoca uma ligeira queda no potencial de crescimento de Batkoa sp., porém prolonga a sobrevivência do fungo até 90 dias, independentemente do tratamento. 


\section{Summary}

\section{Preservation of Batkoa sp. and Furia sp. (Entomophthorales) dry mycelium with combinations of desiccants and oxygen reducers}

Formulation is the most difficult part of Entomophthorales development as biopesticides and bioacaricides, and has caused difficulty in evaluating the Batkoa sp. and Furia sp. for the control of the cercopids Mahanarva fimbriolata and Deois schach, pests of sugar-cane and pastures. A technique for producing dry mycelium of Entomophthorales was previously developed to allow field use of these fungi, but pathogen preservation (shelf life) was not satisfactory. Due these difficulties, the research reported here aimed at evaluating the effect of combinations of two desiccants (silica and glycerol) with two oxygen reducers (vacuum and Ageless ${ }^{\circledR}$ ZPT-200) on the preservation of dry mycelium of Batkoa sp. and Furia sp. under temperatures of $3^{\circ} \mathrm{C}$ and $23^{\circ} \mathrm{C}$. The combination of silica + Ageless ${ }^{\circledR}$ extends the survival of these two fungi formulated as dry mycelium for 90 days, stored at $3^{\circ} \mathrm{C}$ and $23^{\circ} \mathrm{C}$. The use of vacuum to reduce oxygen does not extend the survival of these fungi, even in association with desiccants. Storage at $3^{\circ} \mathrm{C}$ causes a slight decrease in growth potential of Batkoa sp., but it extends fungus survival for 90 days, independent of other treatments.

\subsection{Introdução}

A formulação de Entomophthorales é a etapa mais difícil no seu desenvolvimento como biopesticidas. Isso tem dificultado a avaliação da potência biológica de Batkoa sp. e Furia sp. no controle dos cercopídeos Mahanarva fimbriolata (Fabr., 1787) e Deois schach (Fabr., 1787), pragas da cana-de-açúcar e das pastagens.

Para alguns fungos, foram desenvolvidas metodologias de formulação de esporos de resistência na fase de pré-esporo ou esporo, antes ou após a quebra de dormência, misturando essas estruturas com argila, diluentes, e agentes molhantes e dispersante (Latgé \& Perry, 1981 e Soper \& Ward, 1982). No entanto, para vários outros 
fungos como Batkoa sp. e Furia sp., não se conhece ainda técnicas de produção de esporos de resistência, o que levou Mccabe \& Soper (1985) a desenvolver uma técnica de produção de micélio seco de Entomophthorales. Uma solução de maltose (10\%), pulverizada sobre o micélio fresco, forneceu proteção ao fungo durante o processo de secagem. Os resultados de preservação desses patógenos obtidos com esses estudos foram poucos satisfatórios.

O micélio seco de Zoophthora radicans tratado com maltose e armazenado a $4^{\circ} \mathrm{C}$ manteve boa viabilidade por 80 dias em pesquisa realizada por Pell et al. (1993) e 7 dias por Pell et al. (1998). Essa preservação foi inferior quando o micélio seco foi quebrado em pequenos grânulos e acondicionado a $-20^{\circ} \mathrm{C}$ após a secagem do fungo. Mais recentemente, verificou-se que o armazenamento de conídios de Metarhizium anisopliae em condições de baixa umidade e ausência de oxigênio, reduziu significativamente o metabolismo do patógeno, permitindo a preservação por longo período, mesmo em temperatura ambiente (Jin et al., 1999).

Devido a esssas dificuldades, realizou-se esse estudo visando avaliar o efeito da combinação de dessecantes com redutores de oxigênio na preservação de micélio seco dos fungos Batkoa sp. e Furia sp.

\subsection{Material e Métodos}

Os fungos foram avaliados na forma de grânulos de micélio, sendo obtidos de colônias desenvolvidas em meio de cultura sólido (extrato de levedura - 1\% + glucose $2 \%$ ), após o corte do micélio (crescido na superfície) em porções de 0,8 x 0,8 cm. As porções de micélio foram extraidas, separadas do meio sólido e distribuidas sobre papel de filtro seco e estéril, dentro de placas de Petri de $3,0 \mathrm{~cm}$ de diâmetro, utilizando-se 5 porções de micélio para cada placa.

As placas foram seladas com filme de PVC e mantidas em sala sob temperatura de $23^{\circ} \mathrm{C}$, no escuro, onde permaneceram durante 24 horas para Furia sp. e 48 horas para Batkoa sp. O papel de filtro absorveu o excesso de umidade dos pedaços de micélio, estimulando os fungos a crescerem com maior intensidade. Consequentemente, obteve-se no final desse período de 24 ou 48 horas de incubação, um abundante crescimento micelial com produção de esporos. 
Após esse período, os filmes de PVC foram retirados, expondo as placas ainda tampadas a umidade de $32 \%$ pelo período de 1 ou 2 dias até que a água dentro das placas evaporasse para o ambiente externo, através das pequenas aberturas da tampa, com redução na umidade do fungo para menos de $32 \%$.

As placas contendo os pedaços de micélio seco foram então acondicionadas nas temperaturas de $3^{\circ} \mathrm{C}$ (geladeira) e $23^{\circ} \mathrm{C}$ (ambiente), após serem embaladas sob 8 condições envolvendo diferentes atmosferas e umidades: a) sob vácuo; b) sob vácuo, juntamente com o dessecante glicerol; c) sob vácuo, com glicerol mais um absorvente de oxigênio; d) sob vácuo, com o dessecante sílica; e) sob vácuo, com sílica mais um absorvente de oxigênio; f) sob pressão ambiente, com glicerol; g) sob pressão ambiente, com sílica; h) sob pressão e umidade ambiente (testemunha).

As placas de cada tratamento foram dispostas uma ao lado da outra sobre a tampa invertida de uma placa de Petri de $10 \mathrm{~cm}$ de diâmetro. Para os tratamentos com vácuo, o conjunto foi colocado dentro de um saco plástico de 15 x $19 \mathrm{~cm}$, revestido de nylon, e submetido ao processo de vácuo, utilizado um aparelho doméstico, "Food Saver (®”. Foi utilizado o absorvente de oxigênio Ageless ${ }^{\circledR}$, tipo ZPT 200, o qual tem uma capacidade de absorção de 1,5 litros de oxigênio para cada envelope $(5,5$ x 6,0 cm).

Para os tratamentos com dessecantes, foi utilizado papel de filtro $(9 \mathrm{~cm}$ de diâmetro) umedecido com $2 \mathrm{~mL}$ de glicerol, colocado sob o suporte das placas contendo micélio seco, ou $8 \mathrm{~g}$ de sílica distribuída ao redor das mesmas. Para os tratamentos com absorvente de oxigênio, cada cojunto de placa foi embalado juntamente com um pequeno envelope de Ageless ${ }^{\circledR}$ estendido sobre suas tampas. Para a testemunha, o conjunto foi apenas coberto com a mesma tampa usada para a base e, em seguida, selado com filme PVC.

Realizou-se uma avaliação antes do início do experimento e aos 10, 30 e 60 dias após a primeira. A avaliação constituiu-se da retirada dos pedaços de micélio seco de cada placa, seguido da distribuição dos mesmos sobre meio sólido (extrato de levedura-1\% + glucose-2\%) em placa de Petri de $10,0 \mathrm{~cm}$ de diâmetro. $\mathrm{O}$ fungo foi mantido sob $23^{\circ} \mathrm{C}$, no escuro, e avalido quanto a viabilidade e crescimento (diâmentro de colônia) aos 6 dias para Furia sp. e 10 dias para Batkoa sp., após sua inoculação no meio

Os experimentos foram submetidos a análise de variância e as médias comparadas pelo teste de Tukey $(\mathrm{P}<0,05)$. 


\subsection{Resultados e Discussão}

Na primeira fase do experimento (Figuras 19, 20, 21 e 22), a combinação Vácuo+Sílica+Ageless proporcionou a melhor preservação dos fungos nas duas temperaturas. Esse tratamento foi o único a permitir a sobrevivência dos fungos até 90 dias a $23^{\circ} \mathrm{C}$ (Figuras 19 e 20), mantendo $100 \%$ da viabilidade, com redução nos diâmetros de colônia de 38,5\% para Batkoa sp. e 11,5\% para Furia sp comparados com aqueles iniciais, porém sem diferença significativa (Batkoa sp.: $\mathrm{F}=15,47 ; \mathrm{P}=0,000$. Furia sp.: $\mathrm{F}=$ $121,038 ; \mathrm{P}=0,000)$.

Em condições de geladeira, houve uma queda na viabilidade e potencial de crescimento de Batkoa sp. já a partir do $10^{\underline{O}}$ dia de armazenamento independentemente do tratamento (Figura 21). Por outro lado, o ambiente de geladeira contribuiu para prolongar a sobrevivência do patógeno até 90 dias em todos os tratamentos, porém com redução significativa em alguns deles quanto a viabilidade $(\mathrm{F}=11,21 ; \mathrm{P}=0,000)$, e em todos quanto ao potencial de crescimento $(\mathrm{F}=4,708 ; \mathrm{P}=0,000)$.

Para Furia sp. (Figura 22), as condições em geladeira causaram a inviabilização do patógeno em alguns tratamentos aos 90 dias da avaliação mas mantiveram o fungo vivo em outros além do tratamento Vácuo+Sílica+Ageless. Esse tratamento proporcionou a melhor preservação também em geladeira, mantendo 100\% da viabilidade dos grânulos de micélio seco aos 90 dias, sem afetar significativamente o potencial de crescimento $(\mathrm{F}=$ $24,962 ; \mathrm{P}=0,000)$.

$\mathrm{Na}$ segunda fase do experimento (Tabelas 12 e 13), o tratamento Vácuo+Sílica+Ageless teve eficiência semelhante a Sílica+Ageless para a preservação dos fungos nas duas temperaturas, com os dois tratamentos mantendo a viabilidade dos patógenos acima de $86 \%$ até 90 dias, sem afetar o potencial de crescimento dos mesmos, exceto para Furia sp. acondicionado a $3^{\circ} \mathrm{C}$, com redução no crescimento acima de $36 \%$. 

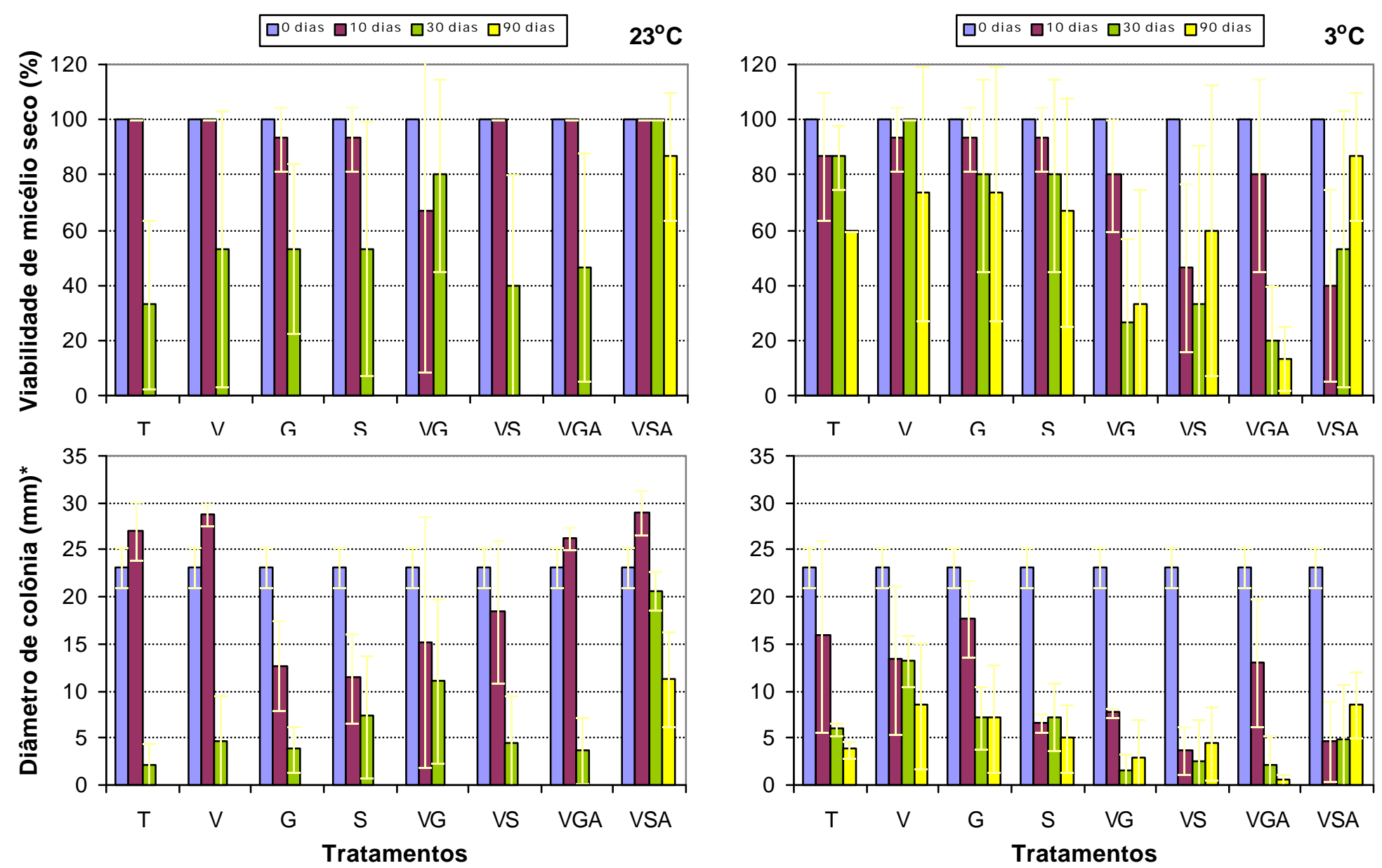

Figura 19 - Viabilidade e crescimento de Batkoa sp. em meio sólido, após diferentes períodos de armazenamento do fungo na forma micélio seco, a $23^{\circ} \mathrm{C}$ e $3^{\circ} \mathrm{C}$, embalado em diferentes combinações envolvendo vácuo (V), glicerol (G), sílica (S), Ageless (A) e testemunha $(\mathrm{T}) .{ }^{*}$ Colônias originadas de grânulos de micélio seco após 6 dias de crescimento. 

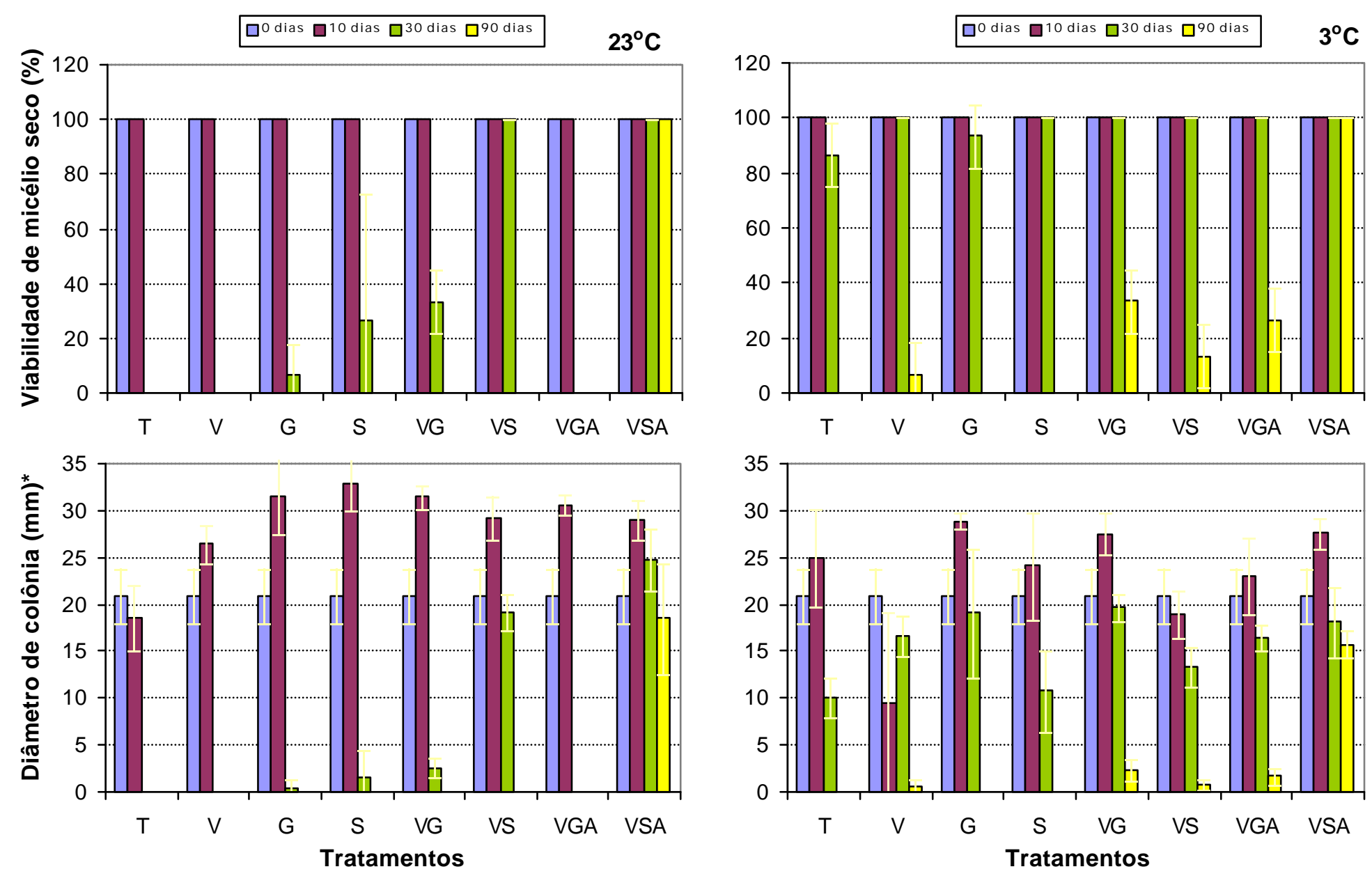

Figura 19 - Viabilidade e crescimento de Furia sp. em meio sólido, após diferentes períodos de armazenamento do fungo na forma micélio seco, a $23^{\circ} \mathrm{C}$ e $3^{\circ} \mathrm{C}$, embalado em diferentes combinações envolvendo vácuo $(\mathrm{V})$, glicerol $(\mathrm{G})$, sílica $(\mathrm{S})$, Ageless (A) e testemunha $(\mathrm{T})$. * Colônias originadas de grânulos de micélio seco após 6 dias de crescimento. 
Tabela 12. Viabilidade e crescimento Batkoa sp. em meio sólido, após 90 dias de armazenamento do fungo na forma de micélio seco, a $3{ }^{\circ} \mathrm{C}$ e $23^{\circ} \mathrm{C}$, embalado em diferentes combinações envolvendo vácuo (V), glicerol (G), sílica (S), Ageless (A) e testemunha (T). * Colonia originada de grânulos de micelio seco após 6 dias de crescimento.

\begin{tabular}{llcccc}
\hline \multirow{2}{*}{ Temperatura } & Tratamento & \multicolumn{2}{c}{ Viabilidade $(\%)$} & \multicolumn{2}{c}{ Diâmetro de colônia (mm) } \\
\cline { 3 - 6 } & & Inicial & Após 90 dias & Inicial & Após 90 dias \\
\hline \multirow{2}{*}{$23^{\circ} \mathrm{C}$} & VSA & 100 & 100 & 14,8 & 20,3 \\
& $\mathrm{SA}$ & 100 & 100 & 14,8 & 21,8 \\
& $\mathrm{~T}$ & 100 & 100 & 14,8 & 0 \\
3 & $\mathrm{VSA}$ & 100 & 100 & 14,8 & 21,9 \\
& $\mathrm{SA}$ & 100 & 100 & 14,8 & 19,4 \\
& $\mathrm{~T}$ & 100 & 100 & 14,8 & 0 \\
\hline
\end{tabular}

Tabela 13. Viabilidade e crescimento Furia sp. em meio sólido, após 90 dias de armazenamento do fungo na forma de micélio seco, a $3^{\circ} \mathrm{C}$ e $23^{\circ} \mathrm{C}$, embalado em diferentes combinações envolvendo vácuo $(\mathrm{V})$, glicerol $(\mathrm{G})$, sílica $(\mathrm{S})$, Ageless (A) e testemunha $(\mathrm{T})$. * Colonia originada de grânulos de micelio seco após 6 dias de crescimento.

\begin{tabular}{llcccc}
\hline \multirow{2}{*}{ Temperatura } & Tratamento & \multicolumn{2}{c}{ Viabilidade $(\%)$} & \multicolumn{2}{c}{ Diâmetro de colonia (mm) } \\
\cline { 3 - 6 } & & Inicial & Após 90 dias & Inicial & Após 90 dias \\
\hline \multirow{2}{*}{$23^{\circ} \mathrm{C}$} & VSA & 100 & 86,7 & 8,35 & 8,1 \\
& SA & 100 & 100 & 8,35 & 10,6 \\
& $\mathrm{~T}$ & 100 & 0 & 8,35 & 0 \\
$33^{\circ} \mathrm{C}$ & $\mathrm{VSA}$ & 100 & 86,7 & 8,35 & 5,3 \\
& $\mathrm{SA}$ & 100 & 86,7 & 8,35 & 4,6 \\
& $\mathrm{~T}$ & 100 & 0 & 8,35 & 0 \\
\hline
\end{tabular}


Condições de prateleira - A combinação Sílica+Ageless, com ou sem vácuo, contribuiu para a preservação desses fungos. Conídios de Beauveria bassiana e M. anisopliae armazenados em um ambiente com baixa concentração de oxigênio e baixa umidade relativa (0-10\%) foram preservados por longo período em condições de prateleira. Nessas condições, o fungo permanece em estado de dormência com baixa atividade fisiológica, suportando temperaturas de até $37^{\circ} \mathrm{C}$.

Para M. anisopliae, a preservação só foi possível enxarcando os conídios, previamente, com $0,05 \%$ do surfactante álcool tridecil etoxilado. Esse surfactante reduz a elevada tensão superficial do conídio, acentuada ainda mais pela secagem, permitindo a rehidratação e germinação do fungo depois de misturado em água (Jin et al., 1999). Micélios desses fungos são geralmente mais tolerantes ao processo de secagem do que conídios. No entanto, formulações de micélio seco têm demonstrado instabilidade sob altas temperaturas e limitadas aplicações no controle de pragas (Jin et al., 1999).

A queda na sobrevivência de Batkoa sp. e Furia sp. pode ser devido ao aumento da umidade ao redor das estruturas dos patógenos, comprovado pela mudança de coloração dos grânulos de sílica indicadora, passando do azul no início do experimento para cor-de-rosa no final, enquanto que no tratamento contendo somente sílica a coloração do dessecante manteve-se inalterada. Isso foi causado, provavelmente, pela água liberada do absorvente de oxigênio conforme o produto reagia com a atmosfera ao longo do tempo. $\mathrm{O}$ ingrediente ativo do Ageless é um óxido de ferro com elevado poder de ação, transformando-se em hidróxidos de ferro após a absorção de oxigênio. Em um compartimento selado, Ageless reduz o oxigênio para 0,01\% (100ppm) ou menos.

Portanto, a morte do fungo ocorreu, provavelmente, pela sua reativação nas condições de umidade devada, e pela ausência de oxigênio para o seu desenvolvimento. $\mathrm{O}$ absorvente de oxigênio foi avaliado, previamente, como único componente para a preservação do fungo, mostrando-se altamente deletério ao patógeno. O oxigênio é exigido pelos fungos para o funcionamento de algumas enzimas oxidases ou monoxidases, responsáveis por algumas reações de hidrólises necessárias para a biossintese do esterol e do ácido graxo insaturado durante o crescimento do patógeno (Griffin, 1994).

Para Z. radicans, o micélio seco tem sido uma das formas possíveis de serem utilizadas em formulações para o controle biológico de pragas. Esse fungo possui uma proteção natural contra a dessecação, proporcionada por uma muscilagem viscosa secretada 
sobre os conidióforos durante a formação dos mesmos, a qual atua também como meio higroscópico que ajuda a manter a pressão de turgor das hifas em crescimento ou como lubrificante das mesmas ( $\mathrm{Li}$ et al., 1993). Apesar disso, esse fungo não apresenta a mesma resistência ao processo de secagem, nem a mesma estabilidade em baixas porcentagens de umidade como os hifomicetos, o que tem dificultado a avaliação do potencial de uso desse patógeno (Pell et al., 1993; Pell et al., 1998).

Nesse experimento, a secagem não afetou a viabilidade devido ao lento processo de desidratação dentro das placas de Petri, com o auxílio do papel de filtro absorvendo o excesso de meio. Também, o meio de cultura retirado juntamente com o patógeno, permitiu maior crescimento do mesmo no início da secagem, protegendo-o contra esse processo pela atuação, principalmente, do açúcar presente no substrato. Esse processo de secagem aproxima-se mais das condições naturais, já que o fungo sobre o hospedeiro é seco juntamente com o substrato.

O micélio de Entomophthorales pode ser induzido a um estado de dormência com a secagem, mantendo-se, no entanto, com atividade fisiológica, provavelmente alta para sua preservação já que a taxa de respiração do micélio é maior que a de conídios (Griffin, 1994). Portanto, o acondicionamento de micélio seco em condições de reduzida concentração de oxigênio além de baixa umidade, provavelmente, reduz a atividade fisiológica, contribuindo para a preservação do patógeno conforme se verificou no experimento.

O uso de vácuo como redutor de oxigênio não prolongou a sobrevivência dos fungos até 90 dias mesmo em associação com sílica, sugerindo que o vácuo não retira ar suficiente para manter o estado de dormência. Não há necessidade do uso de vácuo para a preservação desses Entomophthorales quando se utiliza a combinação de Sílica+Ageless (Tabelas 11 e 12). Também, o dessecante glicerol também não prolongou a sobrevivência devido, provavelmente, a sua menor capacidade de absorção de umidade em relação a sílica.

Condições de geladeira - A geladeira acarretou uma ligeira queda na viabilidade e poder de crescimento do micélio de Batkoa sp. logo após o acondicionamento dos mesmos, mas prolongou a sobrevivência desse fungo até 90 dias, independentemente do tratamento, contribuindo também para a preservação de Furia sp. em alguns tratamentos 
(Vácuo, Vácuo+Glicerol, Vácuo+Sílica, Vácuo+Glicerol+Ageless, Vácuo+Sílica+Ageless). Não houve uma contribuição significativa dos dessecantes para a preservação desses fungos em geladeira ou prateleira, exceto quando a sílica foi utilizada com Ageless. $\mathrm{O}$ acondicionamento de Entomophthorales em ambiente seco, dentro da geladeira, pode permitir a preservação desses fungos sobre o cadáver por até um ano. Entomophaga aulicae foi mantido por um mês no cadáver acondicionado em ambiente seco a $21^{\circ} \mathrm{C}$, sobrevivendo por até 13 meses a $4^{\circ} \mathrm{C}$ ou freezer (Tyrrell, 1988). Condições de freezer também foram testadas com sucesso para a preservação de Neozygites frezenii (Steinkraus, 1993).

Para micélio seco de Batkoa sp. e Furia sp., as condições de freezer foram deletérias, sugerindo que o fungo mantido sobre cadáveres pode ser mais resistente à dessecação em baixas temperaturas (Pell et al., 1998) ou que o cadáver possa oferecer alguma proteção para essas condições. A resistência de Entomophthorales a baixas temperaturas também depende da espécie do patógeno. Assim, Entomophthora aphidis sobreviveu pelo período de 32 semanas a $0^{\circ} \mathrm{C}$ e $20^{\circ} \mathrm{C}$ ou $50 \%$ de umidade relativa em cadáveres do afídeo Acyrthosiphon pisum, enquanto que E. thaxteriana manteve sua viabilidade por 16 semanas na temperatura de $10^{\circ} \mathrm{C}$, a 20 ou $50 \%$ de umidade relativa (Wilding, 1973).

Em geral, o tratamento Sílica+Ageless contribui para a preservação de micélio seco de Entomophthorales em condições de geladeira e principalmente em prateleira. No entanto, o processo de secagem do fungo necessita ainda ser aprimorado. Sugerimos avaliar a preservação desses fungos após a sua secagem com e sem o substrato, comparando-se com a preservação dos mesmos sobre seus hospedeiros naturais.

\subsection{Conclusões}

Os ensaios e observações realizadas permitiram concluir que:

1. A combinação de sílica + Ageless® prolonga a sobrevivência desses dois fungos formulados como micélio seco até 90 dias, armazenados a $3^{\circ} \mathrm{C}$ e $23^{\circ} \mathrm{C}$;

2. O uso de vácuo como redutor de oxigênio rão prolonga a sobrevivência desses fungos, mesmo em associação com dessecantes; 
3. A temperatura de $3^{\circ} \mathrm{C}$ provoca uma ligeira queda no potencial de crescimento de Batkoa sp., porém prolonga a sobrevivência do fungo até 90 dias independentemente do tratamento. 


\section{CONCLUSÕES}

Os ensaios e observações realizadas permitiram concluir que:

1. Batkoa sp. e Furia sp. causam doença na população de Mahanarva fimbriolata e Deois schach, respectivamente;

2. Furia sp. possui maior potencial epizootico que Batkoa sp.;

3. Batkoa sp., Furia sp. e Neozygites floridana se assemelham quanto ao crescimento em meios contendo sais, vitaminas e aminoácido, e em meio completo;

4. A adição de sais ao meio básico proporciona um aumento significativo na produção das três espécies de fungos, e maior do que a adição de vitaminas e aminoácidos;

5. A mistura dos sais $\mathrm{CaCh}_{2} \cdot 2 \mathrm{H}_{2} \mathrm{O}(0,06 \%), \mathrm{KCl}(0,28 \%), \mathrm{MgCl}_{2} \cdot 6 \mathrm{H}_{2} \mathrm{O} \quad(0,16 \%)$, $\mathrm{MgSO}_{4} .7 \mathrm{H}_{2} \mathrm{O}(0,2 \%), \mathrm{NaHCO}_{3}(0,03 \%)$ e $\mathrm{NaH}_{2} \mathrm{PO}_{4} \cdot \mathrm{H}_{2} \mathrm{O}(0,1 \%)$ proporciona maior produção dos fungos do que os sais avaliados isoladamente na concentração de $0,83 \%$.

6. O sulfato de magnésio $\left(\mathrm{MgSO}_{4}\right)$ pode ser utilizado como único sal, na concentração de $0,83 \%$, visando a produção de Batkoa sp., Furia sp. e N. floridana;

7. O meio contendo $2,66 \%$ de glucose proporciona uma produção das três espécies de fungos significativamente maior do que o meio com $2,66 \%$ de sacarose (sucrose); 
8. A adição de $0,1 \%$ de monossacarídeos no meio com $2,66 \%$ de sacarose não aumenta significativamente a produção dos fungos;

9. Batkoa sp., Furia sp. e N. floridana se assemelham quanto ao crescimento em meios contendo diferentes fontes de carbono, mas se diferenciam em meios com diferentes fontes de nitrogênio;

10. O extrato de levedura proporciona maior produção de Batkoa sp.;

11. A concentração de $0,5 \%$ de extrato de levedura é a mais adequada para a produção vegetativa de Batkoa sp. em meio líquido;

12. A combinação de extrato de levedura + extrato de carne + leite desnatado proporciona maior produção de Furia sp.,

13. A combinação de extrato de levedura + leite desnatado proporciona o segundo maior rendimento de Furia sp., sendo mais adequada para a produção do fungo devido ao menor custo;

14. A concentração de $1 \%$ da mistura dessas fontes de nitrogênio é adequada para a produção ve getativa de Furia sp.;

15. A combinação de extrato de levedura + peptona + leite desnatado proporciona a maior produção de N. floridana;

16. A concentração de $3 \%$ da mistura dessas fontes de nitrogênio é a mais adequada para a produção vegetativa de $N$. floridana;

17. A combinação de sílica + Ageless ${ }^{\circledR}$ prolonga a sobrevivência desses dois fungos formulados como micélio seco até 90 dias, armazenados a $3^{\circ} \mathrm{C}$ e $23^{\circ} \mathrm{C}$; 
18. O uso de vácuo como redutor de oxigênio não prolonga a sobrevivência desses fungos, mesmo em associação com dessecantes;

19. A temperatura de $3{ }^{\circ} \mathrm{C}$ provoca uma ligeira queda no potencial de crescimento de Batkoa sp., porém prolonga a sobrevivência do fungo até 90 dias independentemente do tratamento. 


\section{REFERÊNCIAS BIBLIOGRÁFICAS}

ALLAWAY, A.E.; JENNINGS, D.H. The influence of cations on glucose transport and metabolism by, and the loss of sugar alcohols from, the fungus Dendryfiella salina. New Phytolologist, v. 69, p. 581-593, 1970.

ALMEIDA, J.E.M.; BATISTA FILHO, A.; COSTA, V.A.; LEITE, L.G.; RAMIRO, Z.A.; RUSSOMANO, O.M.R.; KRUPPA, P.C.; CALIL, E.M.B. Manejo integrado de pragas e doenças das culturas: pastagens. São Paulo: Secretaria de Agricultura e Abastecimento, 2000. v. 2, 50 p., (Manual Técnico, Série Especial).

ALVARES, J.M.; BELlOTTI, A.C.; BRAUN, A.R.; ACOSTA, A. Estudios de patogenicidad de hongo asociado con Tetranychus urticae Koch, acaro plaga de la yuca. Revista Colombiana de Entomologia, v. 17, p. 28-33, 1991.

ALVES, S.B. Controle biológico de pragas de pastagens. In: SIMPÓSIO SOBRE MANEJO DA PASTAGEM, 7., Piracicaba, 1985. Anais. Piracicaba: FEALQ, 1985. p. 169-208.

ALVES, S.B. Controle microbiano de insetos. São Paulo: Manole, 1986a. p.29-60: Epizootiologia.

ALVES, S.B. Controle microbiano de insetos. São Paulo: Manole, 1986b. p.73-126: Fungos entomopatogênicos. 
ALVES, S.B. Controle microbiano de insetos. Piracicaba: FEALQ, 1998. p. 289-370: Fungos entomopatogênicos.

ALVES, S.B.; ALMEIDA, J.E.M. Controle biológico das pragas das pastagens. In: SIMPÓSIO SOBRE ECOSSISTEMA DE PASTAGENS, 3, Jaboticabal, 1997. Anais. Jaboticabal: FCAV, UNESP, 1997. p. 318-341..

ALVES, S.B.; LECUONA, R.E. Utilización de hongos entomopatógenos. In: LECUONA, R.E.(Ed.). Microorganismos patógenos empleados en el control microbiano de insetos plaga. Buenos Aires: Talleres Gráficos Mariano Mas, 1996. p.241-254.

ARGEL, P.J.; KELLER-GREIN, G. Regional expertice with Brachiaria: Tropical America - humid lowlands. In: Brachiaria: Biology, Agronomy, and Improvement. Campo Grande: CIAT \& EMBRAPA, 1996. p. 205-224.

BALAZY, S. New species of Entomophthoraceae from the Wielkopolski National Park (Poland). Bulletin De L’Academie Polonaise Des Sciences. Classe II, Serie Des Sciences Biologiques, v. 29, p. 221-226, 1981.

BALAZY, S.; WISNIEWSKI, J. Records on some lower fungi occurring in mites (Acarina) in Poland. Acta Mycologica, v. 20, p. 159-172, 1984.

BATISTA FILHO, A.; LEITE, L.G.; TAKADA, H.M.; LAMAS, C.; RAMIRO, Z.A. Incidência do fungo entomopatogênico Batkoa apiculata (Entomophthorales) sobre cigarrinhas das pastagens em Pindamonhangaba, SP. In: REUNIÃO ANUAL DO INSTITUTO BIOLÓGICO, 10, São Paulo, 1997. Resumo. Arquivos do Instituto Biológico, v. 64, p.82, 1997.

BATKO, A. Remarks on the genus Entomophthora Fresenius 1856 non Nowakowski 1883 (Phycomycetes: Entomophthoracese). Bulletin De L'Academie Polonaise Des Sciences. Classe II, Serie Des Sciences Biologiques, v. 12, p. 319-321, 1964a. 
BATKO, A. On the new genera: Zoophthora gen. nov., Triplosporium (Thaxter) gen. nov. and Entomophaga gen. nov. (Phycomycetes: Entomophthoraceae). Bulletin De L’Academie Polonaise Des Sciences. Classe II, Serie Des Sciences Biologiques, v. 12, p. 323-326, $1964 b$.

BATKO, A. Remarks on the genus Lamia Nowakowski 1883 vs. Culicicola Nieuwland 1916 (Phycomycetes: Entomophthoracese). Bulletin De L’Academie Polonaise Des Sciences. Classe II, Serie Des Sciences Biologiques, v. 12, p. 399-402, 1964c.

BATKO, A. Some new combinations in the fungus family Entomophthoraceae (Phycomycetes). Bulletin De L'Academie Polonaise Des Sciences. Classe II, Serie Des Sciences Biologiques, v. 12, p. 403-406,. 1964d.

BATKO, A. On the subgenera of the fungus genus Zoophthora Batko 1964 (Entomophthoraceae). Acta Mycologica, v. 2, p. 15-21, 1966.

BATKO, A.; WEISER, J. On the taxonomic position of the fungus discovered by Strong, Wells and Apple: Strongwellsea castrans gen. nov. et sp. nov. (Phycomycetes: Entomophthoracese). Journal of Invertebrate Pathology., v. 7, p. 455-463, 1965.

BEAUVAIS, A.; LATGÉ, J.P. A simple medium for growing Entomophthoralean protoplasts. Journal of Invertebrate Pathology, v. 51, p. 175-178, 1988.

BEM-ZE'EV, I.; KENNETH, R.G. Feature criteria of taxonomic value in the Entomophthorales: I. A revision of the Batkoa classification. Mycotaxon, v. 14, p. 393$455,1982$.

BENZ, G. Key factors: environment. In: FUXA, J.R.; TANADA, Y. (Ed.) Epizootiology of Insect Diseases. New York: John Wiley, 1987. p. 177-214. 
BOTELHO, W.; SÁ, J.L.C. Ocorrência da mosca sírfida, Salpingogaster nigra Schiner (Diptera-Syrphidae) predando ninfas de cigarrinhas-das-pastagens (HomopteraCercopidae) e alguns dados biológicos observados. In: EMPRESA DE PESQUISA AGROPECUÁRIA DE MINAS GERAIS. Relatório 1974-1979. Belo Horizonte, 1980. p.17-24.

BOZZOLA, J.J.; RUSSELL, L.D. Electron microscopy: principles and techniques for biologists. Boston: Jones and Bartlett, 1992. 542 p.

BRANDENBURG, R.L.; KENNEDY, G.G. Relationship of Neozygites floridana (Entomophthorales: Entomophthoraceae) to twospotted spider mite (Acari: Tetranychidae) populations in field corn. Journal of Economic Entomology, v. 75, n. 4, p. 691-694, 1982.

BROBYN, P.J.; WILDING, N. Invasive and developmental processes of Entomophthora species infecting aphidis. Transactions British Mycological Society, v. 69, n. 3, p. 349366. 1977.

BROBYN, P.J.; WILDING, N.; CLARK, S.J. The persistence of infectivity of conidia of the aphid pathogen Erynia neoaphidis on leaves in the field. Annals of Applied Biology, v. 107, p. 365-376, 1985.

CABANAC, M.; LE GUELTE, L. Temperature regulation and prostaglandin E1 fever in scorpions. Journal of Physiology, v. 303, p. 365-370, 1980.

CARNER, G.R.; CANERDAY, T.D. Entomophthora sp. as a factor in the regulation of the twospotted spider mite on cotton. Journal of Economic Entomology, v. 63, p. 638-640, 1970. 
CARRUTHERS, R.I.; HAYNES, D.L. Temperature, moisture and habitat effects on Entomophthora muscae (Entomophthorales: Entomophthoraceae) conidial germination and survival in the onion agroecosystem. Environmental Entomology, v. 15, p. 1156$1160,1986$.

CARRUTHERS, R.I.; HAYNES, D.L.; MACLEOD, D.M. Entomophthora muscae (Entomophthorales: Entomophthoraceae) mycosis in the onion fly, Delia antiqua (Diptera: Anthomyiidae). Journal of Invertebrate Pathology, v. 45, p. 81-93, 1985.

CARRUTHERS, R.I.; LARKIN, T.S.; FIRSTENCEL, H; FENG, Z. Influence of thermal ecology on the mycosis of a rangeland grasshopper. Ecology, v. 73, n. 1, p. 190-204, 1992.

CARRUTHERS, R.I.; RAMOS, M.E.; LARKIN, T.S., HOSTETTER, D.L.; SOPER, R.S. The Entomophaga grylli (Fresenius) Batko species complex: Its biology, ecology and use for biological control of pest grasshoppers. Memoirs of the Entomological Society of Canada, v. 171, p. 329-353, 1997.

CARRUTHERS, R.I; SOPER, R.S. Fungal diseases. In: FUXA, J.R.; TANADA, Y. (Ed.) Epizootiology of insect diseases. New York: John Wiley, 1987. p. 357-416.

CARVALHO, P. Década vivida. Globo Rural, v. 10, n. 108, p.102-108, 1995.

CASTERLIN, M.E.; REYNOLDS, W.W. Fever induced in marine arthropods by prostaglandin E1. Life Sciences, v. 25, p. 1601-1604. 1979.

COOKE, R.C.; RAYNER, A.D..M. Ecology of saprotrophic fungi. London: Longman, 1984. $294 \mathrm{p}$.

COSENZA, G.W.; NAVES, M.A. O controle da cigarrinha das pastagens. Campo Grande: EMBRAPA/ CNPAC, 1980. 4 p. (Comunicado Técnico, 6). 
COTTAS, M.P.; RAMIRO, Z.A. Flutuação populacional de cigarrinhas das pastagens em duas variedades de Brachiaria na região do Pontal do Paranapanema, Estado de São Paulo. Anais da Sociedade Entomológica do Brasil, v. 10, n. 1, p.51-60, 1981a.

COTTAS, M.P.; RAMIRO, Z.A. Flutuação populaçional de cigarrinhas das pastagens em áreas tratadas e não tratadas com o fungo entomógeno Metarhizium anisopliae (Metsch.) Sorokin, 1883. Biológico, v. 47, n. 9, p.255-261, 1981 b.

DEDRYVER, C.A. Déclenchement em serre d'une épizootie a Entomophthora fresenii sur Aphis fabae par introduction d'inoculum et régulation de l'humidité relative. Entomophaga, v. 24, n. 4, p. 443-453, 1979.

DELALIBERA JR., I.; SOSA GOMES, D.R.; MORAES, G.J. Infection of Mononychellus tanajoa (Acari: Tetranychidae) by the fungus Neozygites sp. (Entomophthorales) in northeastern Brazil. Florida Entomologist, v. 75, n. 1, p. 145-147, 1992.

DELALIBERA-JUNIOR, I; HUMBER, R.A.; BENTO, J.M.S.; MATOS, AP. First record of the entomopathogenic fungus Neozygites fumosa on the cassava mealybug Phenacoccus herreni. Journal of Invertebrate Pathology, v. 69, n. 3, p. 276-278, 1997.

DICK, G.L.; BUSCHMAN, L.L. Seasonal ocurrence of a fungal pathogen, Neozygites adjarica (Entomophthorales: Neozygitaceae), infecting banks grass mites, Oligonychus pratensis, and twospotted spider mites, Tetranychus urticae (Acari: Tetranychidae), in field corn. Journal of the Kansas Entomological Society., v. 68, n. 4, p. 425-436. 1995.

DUSTAN, A.G. Studies on a new species of Empusa parasitic on the green apple bug (Lygus communis var. novascotiensis Knight) in the Annapolis Valley. Proceedings of Acadian Entomological Society, v. 9, p. 14-36, 1923. 
DUSTAN, A.G. The control of the European apple sucker, Psyllia mali Schmidb., in Nova Scotia. Ottawa: Dominion of Canada, Department of Agriculture, 1924. 13 p. (Pamphlet. New Series, 45).

EVANS, H.F.; ENTWISTlE, P.F. Viral diseases. In: FUXA, J.R.; TANADA, Y. (Ed.) Epizootiology of insect diseases. New York: John Wiley, 1987. p. 257-322.

FITZPATRICK, H.M. The lower fungi-phycomycetes. New York: McGraw-Hill, 1930. $331 \mathrm{p}$.

FREIMOSER, F.M.; GRUNDSCHOBER, A.; AEBI, M.; TUOR, U. In vitro cultivation of the entomopathogenic fungus Entomophthora thripidium: isolation, growth requirements, and sporulation. Mycologia, v. 92, n. 2, p. 208-215, 2000.

GALAINI-WRAIGHT, S.; WRAIGHT, S.P.; CARRUTERS, R.I.; MAGALHAES, B.P. \& ROBERTS, D.W. Description of a Zoophthora radicans (Zygomicetes: Entomophthoraceae) epizootic in a population of Empoasca kraemeri (Homoptera: Cicadellidae) on beans in Central Brasil. Journal of Invertebrate Pathology, v.58, p. 311-328, 1991.

GALLO, D.; NAKANO, O.; SILVEIRA NETO, S.; CARVALHO, R.P.L.; BATISTA, G.C.; BERTI FILHO, E.; PARRA， J.R.P.; ZUCCHI， R.A.;ALVES， S.B.; VENDRAMIM, J.D. Manual de entomologia agrícola. São Paulo: Agronômica Ceres, 1988. 649p.

GARRAWAY, M.O.; EVANS, R.C. Fungal Nutrition and Physiology. New York: John Wiley, 1984. $401 \mathrm{p}$.

GEDEN, C.J.; STEINKRAUS, D.C.; RUTZ, D.A. Evaluation of two methods for release of Entomophthora muscae (Entomophthorales: Entomophthoraceae) to infect house flies (Diptera: Muscidae) on dairy farms. Environmental Entomology, v. 22, n. 5, p. 1201$1208,1993$. 
GILES, K.L.; OBRYCKI, J.J. Reduced insecticide rates and strip-harvesting effects on alfalfa weevil (Coleóptera: Curculionidae) larval populations and prevalence of Zoophthora phytonomi (Entomophthorales: Entomophthoraceae). Journal of Economic Entomology, v. 90, n. 4, p. 933-944, 1997.

GILES, K.L.; OBRYCKI, J.J.; DEGOOYER, T.A.; ORR, C.J. Seasonal ocurrence and impact of natural enemies of Hypera posticata (Coleóptera: Curculionidae) larvae in Iowa. Environmental Entomology, v. 23, p. 167-176, 1994.

GLARE, T.R.; MILNER, R.J.; CHILVERS, G.A. The effect of environmental factors on the production, discharge and germination of primary conidia of Zoophthora phalloides Batko. Journal of Invertebrate Pathology, v. 48, p. 275-283, 1986.

GOETTEL, M.S.; SWEENEY, A.W.; ROBERTS, D.W. Effects of drying and hehydration on mycelia of the mosquito pathogenic fungi Culicinomyces clavisporus and Tolypocladium cylindrosporum. Mycologia, v. 81, p. 472-475, 1989.

GRAY, S.N.; MARKHAM, P. A model to explain the growth kinects of the aphidpathogenic fungus Erynia neoaphidis in liquid culture. Mycological Research, v. 101, n. 12, p. 1475-1483, 1997.

GRIFFIN, D.H. Fungal Physiology. New York: Wiley-Liss, 1993. 458 p.

GRONER, A. Production of resting spores of Entomophthora thaxteriana. Journal of Invertebrate Pathology, v. 26, p. 393-394, 1975.

GRUNDSCHOBER, A.; TUOR, U.; AEBI, M. In vitro cultivation and sporulation of Neozygites parvispora (Zygomycetes: Entomophthorales). Systematics and Applied Microbiology, v. 21, p. 461-469, 1998. 
GUAGLIUMI, P. Inimigos naturais da cigarrinha da folha, Marhanarva posticata Stal. Recife: Comissão Executiva de Defesa Fitosanitária da Lavoura Canavieira de Pernambuco, 1969. 37p. (Boletim Técnico, 1).

GUAGliUMi, P. Pragas da cana de açúcar - Nordeste do Brasil. Rio de Janeiro: Instituto do Açúcar e do álcool, 1972. 622 p. (Coleção Canavieira, 10).

HAJEK, A.E.; St. LEGER, R.J. Interactions between fungal pathogens and insect hosts. Annual Review of Entomology, v. 39, p. 293-322, 1994.

HAJEK, A.E.; ROBERTS, D.W. Pathogen reservoirs as a biological control resource: introduction of Entomophaga maimaiga to North American gypsy moth, Lymantria dispar, populations. Biological Control, v. 1, p. 29-34, 1991.

HAJEK, A.E.; CARRUTHERS, R.I.; SOPER, R.S. Temperatura and moisture relations of sporulation and germination by Entomophaga maimaiga (Zygomycetes: Entomophthorales), a fungal pathogen of Lymantria dispar (Lepidoptera: Lymantriidae). Environmental Entomology, v. 19, n. 1, p.85-90, 1990.

HAJEK, A.E.; ELKINTON, J.S.; WITCOSKY, IJ. Introduction and spread of the fungal pathogen Entomophaga maimaiga (Zygomycetes: Entomophthorales) along the leading edge of gypsy moth (Lepdoptera: Lymantriidae) spread. Biological Control, v. 25, n. 5, p. 1235-1247, 1996.

HAJEK, A.E.; LARKIN, T.S.; CARRUTHERS, R.I.; SOPER, R.S. Modeling the dynamics of Entomophaga maimaiga (Zygomycetes: Entomophthorales) epizootics in gypsy moth (Lepdoptera: Lymantriidae) populations. Environmental Entomology, v. 22, n. 5, p.1172-1187, 1993.

HALL, I.M.; BELL, J.V. Nomenclature of Empusa Cohn 1855 vs. Entomophthora Fresenius 1856. Journal of Insect Pathology, v. 4, p. 224-228, 1962. 
HALL, I.M.; DUNN, P.H. Entomophthorous fungi parasitic on the spotted alfafa aphid. Hilgardia, v. 27, p. 159-181, 1957.

HALL, I.M.; PAPIEROK, B. Fungi as biological control agents of arthopods of agricultural and medical importance. Parasitology, v. 84, p. 205-240, 1982.

HAMM, J. Epizootics of Entomophthora aulicae in lepidopterous pests of sorghum. Journal of Invertebrate Pathology, v. 36, p. 60-63, 1980.

HARTRE, E.F. Determination of protein: a modification of the method of the Lowry that gives a linear photometric response. Analytical Biochemistry., v. 48, p.422-427, 1972.

HOLDOM, D.G. Moisture requirements and field occurrence of Entomophthora planchoniana Cornu. In: BAILEY, P.; SWINCER, D. (Eds.), AUSTRALIAN APPLIED ENTOMOLOGY RESEARCH CONFERENCE, 4, Adelaide, 1984. Proceedings. Adelaide: University of Queenland, 1984. p. 24-28.

HUMBER, R.A. An alternative view of certain taxonomic criteria used in the Entomophthorales (Zygomycetes). Mycotaxon, v. 13, p. 191-240, 1981.

HUMBER, R.A. Eryniopsis: a new genus of the Entomophthoraceae (Entomophthorales). Mycotaxon, v. 21, p. 257-264, 1984a.

HUMBER, R.A. Foundations for an evolutionary classification of the Entomophthorales (Zygomycetes). In: WHEELER, Q.; BLACKWELL, M. (Ed.). Fungus-insect relationships: perspectives in ecology and evolution. New York: Columbia University Press, 1984b. p. 166-183.

HUMBER, R.A. Synopsis of a revised classification for the Entomophthorales (Zygomycotina). Mycotaxon, v. 34, p.441-460, 1989. 
HUMBER, R.A. Fungi: identification. In: LACEY, L. (ed.), Manual of techniques in insect pathology. New York: Academic Press, 1997. p. 153-186.

JAQUES, R.P.; PATTERSON, N.A. Control of the apple sucker, Psylla mali Schmidt, by the fungus Entomophthora sphaerosperma (Fresenius). Canadian Entomologist, v. 94, p. $818-825,1962$.

JENNINGS, D.H.; AUSTIN, S. The stimulatory effect of the non-metabolized sugar 3-Omethyl glucose on the conversion of mannitol and arabitol to polysaccharide and other insoluble compounds in the fungus Dendryfiella salina. Journal of General and Applied Microbiology, v. 75, p.: 287-294, 1973.

JENNINGS, D.H.; AYNLEY, J.S. Compartmentation and low temperature fluxes of potassium of mycelium of Dendryfiella salina. New Phytolologist, v. 70, p. 713-723, 1971.

JIN, X.; GRIGAS, K.E.; JOHNSON, C.A.; PERRY, P.; MILLER, D.W. Method for storing fungal conidia. U.S. Patent 5, 989, 898 nov. 1993.

KELLER, S. Arthropod-pathogenic Entomophthorales of Switzerland. II. Conidiobolus, Entomophaga and Entomophthora. Sydowia, v. 40, p. 122-167, 1987.

KELLER, S. Arthropod-pathogenic Entomophthorales of Switzerland. II. Erynia, Eryniopsis, Neozygites, Zoophthora and Tarichium. Sydowia, v. 43, p. 39-122, 1991.

KELLER, S. The genus Neozygites (Zygomycetes, Entomophthorales) with special reference to species found in tropical regions. Sydowia, v. 49, n. 2, p. 118-146, 1997.

KENNETH, R.G.; WALLIS, G.; GERSON, U.; PLAUT, H.N. Observations and experiments on Triplosporium floridanum attacking spider mites in Israel. Journal of Invertebrate Pathology, v. 19, p. 366-369, 1972. 
KEVORKIAN, A.G. Studies in the Entomophthoraceae. 1. Observations on the genus Conidiobolus. Journal of Agriculture of the University of Puerto Rico, v. 21, p. 191200, 1937.

KNUDSEN, G.R.; JOHNSON, J.B.; ESCHEN, D.J. Alginate pellet formulation of a Beauveria bassiana (Fungi: Hyphomycetes) isolate pathogenic to cereal aphids. Journal of Economic Entomology, v. 83, p. 2225-2228, 1990.

KNUDSEN, G.R.; ESCHEN, D.J.; DANDURAND, L.M.; WANG, Z.G. Method to enhance growth and sporulation of pelletized biocontrol fungi. Applied and Environmental Microbiology, v. 57, p. 2864-2867, 1991.

KRAMER, J.P. The house fly mycosis caused by Entomophthora muscae. Effect of relative humidity on infectivity and conidial germination. Journal of New York Entomological Society, v. 88, p. 236-240, 1980.

KREUGER, S.R.; VILLANI, M.G.; MARTINS A.S.; ROBERTS, D.W. Efficacy of soil applications of Metahizium anisopliae (Metsch.) Sorokin conidia, and standard and lyophilized mycelial paticles against scarab grubs. Journal of Invertebrate Pathology, v. 59, p. 54-60, 1992.

LAMB, D.J.; FOSTER, G.N. Some observations on Strongwellsea castrans (Zygomicetes: Entomophthorales), a parasite of root flies (Delia spp.) in the south of Scotland. Entomophaga, v. 31, n. 1, p. 91-97, 1986.

LATGÉ, J.P. Croissance et sporulation de 6 espèces d'Entomophthorales. I. Influence de la nutrition carbonée. Entomophaga, v. 20, n. 2, p. 201-207, 1975a.

LATGÉ, J.P. Croissance et sporulation de 6 espèces d'Entomophthorales. II. Influence de diverses sources d'azote. Mycopathologia, v. 57, n. 1, p. 53-57, 1975 b.

LATGÉ, J.P. Comparaison des exigences nutritionnelles des Entomophthorales. Annals of Microbiology, v. 132B, p. 299-306, 1981. 
LATGÉ, J.P. Production of Entomophthorales. In: INTERNATIONAL COLLOQUIUM ON INVERTEBRATE PATHOLOGY, 3, Brighton, 1982. Proceedings. Brighton: University of Sussex, 1982. p. 164-169.

LATGÉ, J.P.; PERRY, D.F. The utilization of an Entomophthora obscura resting spore preparation in biological control experiments against cereal aphids. Bulletin. Organization Internationale de Lutte Biologique/Section Régionale Ouest Paleartique. v. 3, n. 4, p. 19-25, 1980.

LATGÉ, J.P.; REMAUDIÈRE, G. Croissance et sporulation de 6 espèces d'Entomophthorales. III. Influence de concentrations de carbone et d'azote et du rapport C/N. Revue de Mycologie, v. 39, p. 239-250, 1975.

LATGÉ, J.P.; SANGLIER, J.J. Optimisation de la croissance et de la sporulation de Conidiobolus obscurus en milieu défini. Canadian Journal of Botany, v. 63, p. 68-85, 1985.

LATGÉ, J.P.; REMAUDIÈRE, G.; DIAQUIM, M. Um nouveau milieu pour la croissance et la sporulation d'Entomophthorales pathogènes d'aphides. Annales de Microbiologie, v. 120, p. $463-476,1978$.

LATGÉ, J.P.; SOPER, R.S.; MADORE, C.D. Media suitable for industrial production of Entomophthora virulenta zygospores. Biotechnology and Bioengineering, v. 19, p. 1269-1284, 1977.

LE RÜ, B.; IZIQUEL, Y. Nouvelles données sur le déroulement de la mycose à Neozygites fumosa sur la cochenille du manioc Phenacoccus manihoti. Entomophaga, v. 35, n. 2, p. $173-183,1990$. 
LEITE, L.G. Estudo de alguns fatores que afetam a epizootia de Zoophthora radicans e utilização do fungo para o controle de Empoasca sp. Piracicaba,. 1991. 117 p. Dissertação (Mestrado) - Escola Superior de Agricultura "Luis de Queiroz", Universidade de São Paulo.

LEITE, L.G.; BATISTA FILHO, A.B.; MACHADO, L.A.; COSTA, V.A. Utilização do fungo Zoophthora radicans para o controle da cigarrinha-verde do feijão, Empoasca sp. In: CICLO DE PALESTRAS SOBRE CONTROLE BIOLÓGICO DE PRAGAS, 3, Campinas, 1993. Campinas: Instituto Biológico, 1993. p.59-62.

LEITE, L.G.; ALVES, S.B.; WRAIGHT, S.P.; GALAINI WRAIGHT, S.; ROBERTS, D.W. Comportamento de isolados do fungo Zoophthora radicans sobre Empoasca kraemeri. Ecossistema, v. 21, p.16-22, 1996a.

LEITE, L.G.; ALVES, S.B.; WRAIGHT, S.P.; GALAINI WRAIGHT, S.; ROBERTS, D.W. Processos de germinação de isolados do fungo Zoophthora radicans sobre Empoasca kraemeri. Scientia Agricola, v. 53, n. 1, p. 179-183, 1996 b.

LEITE, L.G.; SMITH, L.; MORAES, G.J.; ROBERTS, D.W. In vitro production of hyphal bodies of the mite pathogenic fungus Neozygites floridana. Mycologia, v. 92, p. 201207, 2000.

LEITE, L.G.; ALVES, S.B.; WRAIGHT, S.P.; GALAINI WRAIGHT, S.; ROBERTS, D.W. Habilidade de infecção de isolados de Zoophthroa radicans sobre Empoasca kraemeri. Scientia Agricola, v. 53, n. 1, p. 152-158, 1996c.

LEITE, L.G.; ALVES, S.B.; WRAIGHT, S.P.; GALAINI-WRAIGHT, S.; ROBETS, D.W.; MAGALHAES, B.P. Conidiogênese de Zoophthora radicans (Brefeld) Humber sobre Empoasca kraemeri (Ross\& Moore), a diferentes temperaturas. Arquivos do Instituto Biológico, v. 63, n. 1, p. 47-53, 1996d. 
LEITE, L.G.; BATISTA FILHO, A.; CRUZ, B.P.B. Crescimento vegetativo do fungo Zoophthora radicans (Brefeld) Humber em diferentes meios de cultura naturais. Arquivos do Instituto Biológico, v. 58, n. 1/2, p. 21-24, 1991.

LEPAGE, H.S. ; MONTE, O. As cigarrinhas do capim "kikuio". O Biológico, v. 8, n. 12, p.255-259, 1942.

LI, Z.; BUTT, T.M.; BECKETT, A.; WILDING, N. The structure of dry mycelia of the entomophthoralean fungi Zoophthora radicans and Erynia neoaphidis following different preparatory treatments. Mycological Research, v. 97, p. 1315-1323, 1993.

LUNAU, S.; STOESSEL; S.; SCHMIDT-PEISKER, A.J.; EHLERS, R.U. Establishment of monoxenic inocula for scaling up in vitro cultures of the entomopathogenic nematodes Steinernema spp. and Heterorhabditis spp. Nematologia, v. 39, p. 385-399. 1993.

MACCABE, D.; SOPER, R.S. Preparation of an entomopathogenic fungal insect control agent. U.S. Patent 4, 530, 834 jul. 1985.

MACLEOD, D.M. Entomophthorales infections. In: STEINHAUS, E.A. (Ed.) Insect pathology: an advanced treatise. New York: Academic Press, 1963. v. 2, p. 189-231.

MACLEOD, D.M. Notes on the genus Empusa Cohn. Canadian Journal of Botany, v. 34, p. 16-26, 1956.

MACLEOD, D.M.; MÜLLER-KOGLER, E. Insect pathogens: species originally described from their resting spores mostly as Tarichium species (Entomophthorales: Entomophthoraceae). Mycologia, v. 62, p. 33-66, 1970. 
MAGALHÃES, B.P.; BICELLI, R.L.; PARRA, J.R.P.; HADDAD, M.L. Influência de temperatura e da umidade relativa sobre ovos de cigarrinha das pastagens, Deois incompleta em Brachiaria spp. In: CONGRESSO BRASILEIRO DE ENTOMOLOGIA, 9., Londrina, 1984. Resumos. Londrina: SEB, 1984. p. 42-43.

MAGALHÃES, B.P.; LORD, J.C.; WRAIGHT, S.P.; DAOUST, R.A.; ROBERTS, D.W. Pathogenicity of Beauveria bassiana and Zoophthora radicans to the coccinellid predators Coleomegilla maculata and Eriops connexa. Journal of Invertebrate Pathology, v. 52, p. 471-473, 1988.

MCDONALD, D.M.; NOLAN, R.A. Effect of relative humidity and temperature on Entomophaga aulicae conidium discharge from infected eastern hemLock looper larvae and subsequent conidum development. Journal of Invertebrate Pathology, v. 65, n. 2, p.83-90, 1995.

MCGUIRE, M.R.; MADDOX, J.V.; ARMBRUST, E.J. Effect of temperature on distribution and success of introduction of an Empoasca fabae (Homoptera: Cicadellidae) isolate of Erynia radicans (Zygomycetes: Entomophthoraceae). Journal of Invertebrate Pathology, v. 50, p. 291-301, 1987a.

MCGUIRE, M.R.; MORRIS, M.J.; ARMBRUST, E.J.; MADDOX, J.V. An epizootic caused by Erynia radicans (Zygomicetes: Entomophthoraceae) in an Illinois Empoasca fabae (Homoptera: Cicalellidae) population. Journal of Invertebrate Pathology, v. 50, p. $78-80,1987$ b.

MELO, L.A.S.; SILVEIRA NETO, S. Tipos de amostragens e evolução populacional das cigarrinhas das pastagens. Pesquisa Agropecuária Brasileira, v. 18, n. 12, p. 1303$1309,1983$.

MELO, L.A.S.; SILVEIRA NETO, S.; VILLA NOVA, N.A.; REIS, P.R. Influencia de elementos climáticos sobre a população de cigarrinhas-das-pastagens. Pesquisa Agropecuária Brasileira, v. 19, n. 1, p.9-19, 1984. 
MILANEZ, J.M.; MILDE, L.C.E.; PARRA, J.R.P.. Estimativa da constante térmica das cigarrinhas das pastagens Zulia (Notozulia) entreriana (Berg, 1879) e Deois (Acanthodeois) flavopicta (Stal, 1854) (Homoptera: Cercopidae) em condições de campo. Anais da Sociedade de Entomologia do Brasil, v. 12, n. 2, p.151-163, 1983.

MILLSTEIN, J.A.; BROWN, G.C.; NORDIN, G.L. Microclimatic humidity influence on conidial discharge in Erynia sp. (Entomophthorales: Entomophthoraceae), an entomopathogenic fungus of the alfalfa weevil (Coleoptera: Curculionidae). Environmental Entomology, v. 11, n. 6, p. 1166-1169, 1982.

MILLSTEIN, J.A.; BROWN, G.C.; NORDIN, G.L. Microclimatic moisture and conidial production in Erynia sp. (Entomophthorales: Entomophthoraceae): in vivo moisture balance and conidiation phenology. Environmental Entomology, v. 12, n. 5, p. 1339$1343,1983$.

MILNER, R.J. Pattern of primary spore discharge of Entomophthora spp. from blue green aphid, Acyrthosiphon kondoi. Journal of Invertebrate Pathology, v. 38, p. 419-425, 1981.

MILNER, R.J.; SOPER, R.S. Bioassay of Entomophthora against the spotted alfalfa aphid Therioaphis trifolii f. maculata. Journal of Invertebrate Pathology, v. 37, p. 168-173, 1981.

MILNER, R.J.; LUTTON, G.G.; BOURNE, J. A Laboratory study of the interaction between aphids, fungal pathogens and parasites. In: BAILEY, P.; SWINCER, D. (Eds.), AUSTRALIAN APPLIED ENTOMOLOGY RESEARCH CONFERENCE, 4, Adelaide, 1984. Proceedings. Adelaide: University of Queenland, 1984. p. 375-381.

MILNER R.J.; SOPER, R.S.; LUTTON, G.G. Field release of an Israeli strain of the fungus Zoophthora radicans (Brefeld) Batko for biological control of Therioaphis trifolii (Monell) f. maculata. Journal of Australian Entomology Society, v. 21, p. 113$118,1982$. 
MISSONIER, J.; ROBERT, Y.; THOIZON, G. Circunstances épidemiologiques semblant favoriser le développement des mycoses a Entomophthorales chez trois aphides, Aphis fabae Scop., Capitophorus horni Borner et Myzus persicae Sulz. Entomophaga, v. 15, p. $169-130,1970$.

MORAES, G.J.; DELALIBERA JR., I. Specificity of a strain of Neozygites sp. (Zygomicetes: Entomophthorales) to Mononychellus tanajoa (Acari: Tetranychidae). Experimental \& Applied Acarology, v. 14, p. 89-94, 1992.

MORRIS, M.J.; ROBERTS, S.J.; MADDOX, J.V.; ARMBRUST, E.J. Epizootiology of the fungal pathogen, Zoophthora phytonomi (Zygomycetes: Entomophthorales) in field populations of alfalfa weevil (Coleoptera: Curculionidae) larvae in Illinois. The Great Lakes Entomologist, v. 29, n. 3, p. 129-140, 1996.

MULLER-KOGLER, E. Zur isolierung und kultur insektenpathogener Entomophthoraceen. Entomophaga, v. 4, p. 261-267, 1959.

NADEAU, M.P.; DUNPHY, G.B.; BOISVERT, J.L. Effects of physical factors on the development of secondary conidia of Erynia conica (Zygomycetes: Entomophthorales), a pathogen of adult black flies (Diptera: Simuliidae). Experimental Mycology, v. 19, p. 324-329, 1995.

NEMOTO, H.; AOKI, J. Entomophthora floridana (Entomophthorales: Entomophthoraceae) attacking the sugi spider mite, Oligonychus hondoensis (Acarina: Tetranychidae) in Japan. Applied Entomology and Zoology, v. 10, p. 90-95, 1975.

NEVES, P.M.O.J.; TAMAI, M.A.; ALVES, S.B. 1997. Processo de infecção e reprodução de Beauveria bassiana em Tetranychus urticae (Koch) (Acari: Tetranychidae). P. 138. In: CONGRESSO BRASILEIRO DE ENTOMOLOGIA, 16., Salvador, 1997. Resumos. Salvador: SEB, 1997. p. 400. 
NEWMAN, G.G.; CARNER, G.R. Environmental factors affecting conidial sporulation and germination of Entomophthora gammae. Environmental Entomology, v. 4, p. 615$618,1975$.

NOLAN, R.A. Na inexpensive medium for mass fermentation production of Entomophaga aulicae hyphal bodies competent to form conidia. Canadian Journal of Microbiology, v. 39, n. 6, p.588-593, 1993.

ODUOR, G.I.; MORAES, G.J.; YANINEK, J.S.; VAN DER GEEST, L.P.S. Effect of temperature, humidity and photoperiod on mortality of Mononychellus tanajoa (Acari: Tetranychidae) infected by Neozygites floridana (Zygomicetes: Entomophthorales). Experimental \& Applied Acarology, v. 19, p. 571-579, 1995.

ODUOR, G.I.; MORAES, G.J.; VAN DER GEEST, L.P.S.; YANINEK, J.S. Production and germination of primary conidia of Neozygites floridana (Zygomycetes: Entomophthorales) under constant temperatures, humidities, and photoperiods. Journal of Invertebrate Pathology, v. 68, n. 3, p. 213-222, 1996 a.

ODUOR, G.I.; YANINEK, J.S.; VAN DER GEEST, L.P.S.; MORAES, GJ. Germination and viability of capilliconidia of Neozygites floridana (Zygomycetes: Entomophthorales) under constant temperature, humidity, and light conditions. Journal of Invertebrate Pathology, v. 67, p. 267-278, 1996 b.

ODUOR, G.I.; YANINEK; J.S.; MORAES, G.J.; GEEST, L.P.S. The effect of pathogen dosage on the pathogenicity of Neozygites floridana (Zygomycetes: Entomophthorales) to Mononychellus tanajoa (Acari: Tettranychidae). Journal of Invertebrate Pathology, v. 70, n. 2, p. 127-130, 1997.

PAPIEROK, B.; HAJEK, A.E. Fungi: Entomophthorales. In: LACEY, L. (Ed.) Manual of techniques in insect pathology. New York: Academic Press, 1997. p. 187-212. 
PAPIEROK, B.; WILDING, N. Mise en évidence d'une différence de sensibilité entre 2 clones du puceron du pois Acyrthosiphon pisum Harr. (Homoptère: Aphididae) exposés à 2 souches champignon phycomycéte Entomophthora obscura Hall \& Dunn. Comptes Rendus de L’Académie des Sciences. Paris, Série D., v. 288, p. 93-95, 1979.

PELL, J.K.; WILDING, N. Preliminary caged-field trial, using the fungal pathogen Zoophthora radicans Brefeld (Zygomycetes: Entomophthorales) against the diamondback moth Plutella xylostella L. (Lepidoptera: Yponomeutidae) in the UK. Biocontrol Science and Technology, v. 4, n. 1, p. 71-75, 1994.

PELL, J.K.; MACAULEY, E.D.M.; WILDING, N. A pheromone trap for dispersal of the pathogen Zoophthora radicans Brefeld (Zygomycetes: Entomophthorales) amongst populations of the diamondback moth, Plutella xylostella L. (Lepidoptera: Yponomeutidae). Biocontrol Science and Technology, v. 3, p. 315-320, 1993.

PELL, J.K.; BARKER, A.D.P.; CLARK, S.J.; WILDING, N.; ALDERSON, P.G. Use of a novel sporulation and storage on conidiation by dried mycelia of the Entomopathogenic fungus Zoophthora radicans. Biocontrol Science and Technology, v. 8, p. 13-21, 1998.

PEREIRA, R.M.; ROBERTS, D.W. Alginate and corrnstarch mycelial formulations of entomopathogenic fungi, Beauveria bassiana and Metarhizium anisopliae. Journal of Economic Entomology, v. 84, p. 1657-1661, 1991.

PEREIRA, R.M.; ROBERTS, D.W. Dry mycelium preparation of entomopathogenic fungi, Metarhizium anisolpliae and Beauveria bassiana. Journal of Invertebrate Pathology, v. 56, p. 39-46, 1990.

PERRY, D.F.; LATGÉ, J.P. Chemically defined media for growth and sporulation of Entomophthora virulenta. Journal of Invertebrate Pathology, v. 35, p. 43-48, 1980. 
POWEL, W.; WILDING, N.; BROBYN, P.J.; CLARK, S.J. Interference between parasitoids (Hym.: Aphidiidae) and fungi (Entomophthorales) attacking cereal aphids. Entomophaga, v. 31, n. 3, p. 293-302, 1986.

RAMIRO, Z.A.; COTTAS, M.P. ensaio de campo com diferentes dosagens de Metarhizium anisopliae (Metch.) Sorokin, 1883, visando o controle de Deois flavopicta (Stal, 1824) e Zulia entreriana (Berg, 1879) em pastagens. Biológico, v. 45, n. 11/12, p.199-204, 1979.

REMAUDIÈRE, G.; HENNEBERT, G.L. Révision systématique des genres d'Entomophthora aphidis Hoffm. in Fres. Description de deux nouveaus pathogènes d'aphides. Mycotaxon, v. 11, p. 323-338, 1980.

REMAUDIÈRE, G.; KELLER, S. Revision systematique des genres d'Entomophthoraceae à potencialité entomopathogène. Mycotaxon, v. 11, p. 323-338, 1980.

RINALDI, I.M.P. Aranhas no Controle Biológico de Insetos: Fatos e Perspectivas. In: CIClO DE PALESTRAS SOBRE CONTROLE BIOLÓGICO DE PRAGAS, 4., Campinas, 1995. Campinas: SEB, 1995. p.155-177

ROBERTS, D.W.; DUNN, H.M.; RAMSAY, G.; SWEENEY, A.W.; DUNN, N.W. A procedure for preservation of the mosquito pathogen Culicinomyces clavisporus. Applied Microbiology and Biotechnology, v. 26, p. 186-188, 1987.

ROMBACH, M.C.; AGUDA, R.M.; SHEPARD, B.M.; ROBERTS, D.W. Entomopathogenic fungi (Deuteromycotina) in the control of the black bug of rice, Scotinophara coarctata (Hemiptera: Pentatomidae). Journal of Invertebrate Pathology, v. 48, p. 174-179, 1986.

SAWYER Jr., W.H. Observations on some entomogenous members of the Entomophthoraceae in artificial culture. American Journal of Botany, v. 16, p. 87-121, 1929. 
SCHOFFENIELS, E.;GILLES, R. Nitrogenous constituents and nitrogen metabolism in Arthropods. In: FLORKIN, M.; SCHEER, B.T. (Ed.) Chemical zoology: arthropoda, part A. New York: Academic Press, 1970. p. 199-227.

SHAH, P.A.; AEBI, M.; TUOR, U. Method to immobilize the aphid-pathogenic fungus Erynia neoaphidis in an alginate matrix for biocontrol. Applied and Environmental Microbiology, v. 64, n. 11, p. 4260-4263, 1998.

SIEGENTHALER, P.A.; BELESKY, M.; GOLDSTEIN, S. Phosphate uptake in na obligately marine fungus: A specific requirement of sodium. Science, v. 155, p. 93-94, 1967.

SILVEIRA NETO, S.; MARCHINI, L.C.; ALVES, S.B. Pragas das pastagens. In: CURSO DE ENTOMOLOGIA APLICADA À AGRICULTURA. Piracicaba, 1992. Piracicaba: FEALQ, 1992. p. 335- 353.

SILVEIRA NETO, S.; PARRA, J.R.P.; ZUCCHI, R.A.; ALVES, S.B.. Zoneamento ecológico para as cigarrinhas-de-pastagens (Homoptera: Cercopidae) no Brasil. Anais da Sociedade Entomológica do Brasil, v. 15, p.149-159, 1986. Suplemento.

SILVIE, P. Survie experimentale des corps hyphaux de Erynia neoaphidis, entomophthorale pathogene de pucerons. Paris, 1983. 103 p. These (Docteur) - Centre d'Orsay, Universite de Paris-Sud.

SIX, D.L.; MULLENS, B.A. Distance of conidial discharge of Entomophthora muscae and Entomophthora schizophorae (Zygomycotina: Entomophthorales). Journal of Invertebrate Pathology, v. 67, n. 3, p. 253-258, 1996.

SMITH, M.C.W. The nutrition and physiology of Entomophthora coronata W. (Cost.) Kevorkian. Ann Arbor, 1953. 91 p., Thesis (Ph.D.), University of Michigan. 
SOPER R.S. Erynia radicans as a mycoinsecticide for spruce budworm control. In: SYMPOSIUM: MICROBIAL CONTROL OF SPRUCE BUDWORMS AND GYPSY MOTHS, Windsor Jacks, 1985. Proceedings, Windsor Jacks: USDA, Forest Service, 1985. p. 69-76.

SOPER, R.S.; MACLEOD, D.M. Descriptive epizootiology of an aphid mycosis. Washington: USDA, 1981. 17 p. (Technical Bulletin, 1632).

SOPER, R.S.; WARD, M.G. Production formulation and application of fungi for insect control. In: PAPAVIZAS, G.C. (Ed.) Biological control in crop production. New York: Allanhed \& Osmun Publ., 1981. p. 161-180.

SOPER, R.S.; HOLBROOK, F.R.; MAJCHROWICZ, I.; GORDON; C.C. Production of Entomophthora resting spores for biological control of aphids. Maine: University of Maine at Orono, 1975. 15 p. (Technical Bulletin, 76).

SPEARE, A.T. Fungi parasitic upon insects injurious to sugar cane. Honolulu: Hawaiian Sugar Planters Association., 67 p. 1912. (Pathological and Physiological Series, Bulletin 12).

STANLEY-SAMUELSON, D.W.; JENSEN, E.; NICKERSON, K.W.; TIEBEL, K.; OGG, C.L.; HOWARD, R.W. Insect immune response to bacterial infection is mediated by eicosanoids. Proceedings of the National Academy of Sciences of the United States of America, v. 88, p. 1064-1068, 1991.

STEINHAUS, E.A. Principles of insect pathology. New York: McGraw-Hill, 1949. $757 \mathrm{p}$.

STEINKRAUS, D.C.; HOLLINGSWOTH, R.G.; SLAYMAKER, P.H. Prevalence of Neozygites fresenii (Entomophthorales: Neozygitaceae) on cotton aphids (Homoptera: Aphididae) in Arkansas cotton. Environmental Entomology, v. 24, n. 2, p. 465-474, 1995. 
STEINKRAUS, D.C.; OLIVER, J.B.; HUMBER, R.A.; GAYLOR, M.J. Mycosis of bandedwinged whitefly ( Trialeurodes abutilonea) (Homoptera: Aleyrodidae) caused by Orthomyces aleyrodis gen. and sp. nov. (Entomophthorales: Entomophthoraceae). Journal of Invertebrate Pathology, v. 55, p. 289-290, 1998.

SYKES, E.E.; PORTER, D. Nutritional studies of Labyrinthula sp. Mycologia, v. 65, p. 1302-1311, 1973.

THAXTER, R. The Entomophthoreae of the United States. Memoirs of Boston Society of Natural History, v. 4, p. 133-201, 1888.

TORIELLO, C.; HERNANDEZ-IBANEZ, J.M.; LOPEZ-MARTINEZ, R.; MARTINEZ, A.; LOPEZ-GONZALEZ, L.; MIER, T.; CARRILLO, J.; LATG'E, J.P. The pathogenic fungi of the spittlebug in Mexico. III. Innocuity of Erynia neoaphidis and Conidiobolus major in experimental animals. Entomophaga, v. 31, n. 4, p. 371-376, 1986.

TYRRELL, D. Survival of Entomophaga aulicae in dried insect larvae. Journal of Invertebrate Pathology, v. 52, p. 187-188, 1988.

UZIEL, A.; KENNETH, R.G. Survival capacity of capilloconídia over puimary conidia at low humidity in Erynia (Subgen. Zoophthora) and Neozygites fresenii (Zygomycetes: Entomophthorales). In: INTERNATIONAL COLLOQUIUM OF INVERTEBRATE PATHOLOGY, 4, Wageningen, 1986. Fundamental and Applied Aspects of Invertebrate Pathology: proceedings. Wageningen: Foundation of the Fourth International Colloquium of Invertebrate Pathology, 1986. p. 231.

VALÉRIO, J.R.; KOLLER, W.W. Cigarrinhas das pastagens: inimigos naturais encontrados na região de Campo Grande, MS. Brasília: EMBRAPA, CNPAC, 1982. 3p. (Comunicado Técnico, 8). 
VANDENBERG, J.D. Safety of four entomopathogens for caged adult honey bees (Hymenoptera: Apidae). Journal of Economic Entomology, v. 83, n. 3, p.755-759, 1990.

VANDENBERG, J.D.; SOPER, R.S. Prevalence of Entomophthorales mycoses in populations of spruce budworm, Choristoneura fumiferana. Environmental Entomology, v. 7, n. 6, p. 847-853, 1978.

VIÉGAS, A.P. Empusa dysderci n. sp., um novo parasita de Dysdercus Jornal de Agronomia, v. 2, p. 229-258, 1939.

VILLACARLOS, L.T.; KELLER, S. Batkoa amrascae Keller \& Villacarlos, a new species of Entomophthorales (Zygomycetes) infecting the cotton leafhopper, Amrasca biguttula (Ishida) (Homoptera: Cicadellidae) in the Philippines. The Philippine Entomologist, v. 11, n. 1, p. 81-86. 1997.

WATSON, D.W.; MULLENS, B.A.; PETERSEN, J.J. Behavioral fever response of Musca domestica (Diptera: Muscidae) to infection by Entomophthora muscae (Zygomycetes: Entomophthorales). Journal of Invertebrate Pathology, v. 61, p. 10-16, 1993.

WEBSTER, J. Introduction to fungi. Cambridge: Cambridge University Press, 1980. $669 \mathrm{p}$.

WEISER, J. Triplosporium tetranychi sp. nov. (Phycomycetes: Entomophthoraceae), a fungus infecting the red mite, Tetranychus altheae Hanst. Folia Parasitologica, v. 15, p. 115-122, 1968.

WEISER, J.; MUMA, M.H. Entomophthora floridana sp. nov. (Phycomycetes: Entomophthoraceae), a parasite of the Texas citrus mite, Eutetranychus banksi. Florida Entomologist, v. 49, p. 155-159, 1966. 
WELTON, M.A.; TYRRELL, D. A note on the isolation of Entomophthora species on artificial media. Journal of Invertebrate Pathology, v. 26, p. 405, 1975.

WESELOH, R.M.; ANDREADIS, T.G. Persistence of resting spores of Entomophaga maimaiga, a fungal pathogen of the gypsy moth, Lymantria dispar. Journal of Invertebrate Pathology, v. 69, n. 2, p.195-196, 1997.

WHEELER, A.G.J. "Violent deaths" of soldier beetles (Coleoptera: Cantharidae) revisited: The fungal pathogen Eryniopsis lampyridarum, new record (Zygomycetes: entomophthoraceae). Coleopterists Bulletin., v. 42, p. 233-236, 1988.

WILDING, N. Effect of humidity on the sporulation of Entomophthora aphidis and E. thaxteriana. Transactions of the British Mycological Society, v. 53, n. 1, p.126-130, 1969.

WILDING, N. The effect of temperature on the infectivity and incubation period of the fungi Entomophthora aphidis and E. thaxteriana on the pea aphid, Acyrthosiphon pisum. In: INTERNATIONAL COLLOQUIUM ON INSECT PATHOLOGY, 4, College Park, 1970. Proceedings. College Park: University of Maryland, 1970. p. 84-88.

WILDING, N. The survival of Entomophthora spp. in mummified aphids at different temperatures and humidities. Journal of Invertebrate Pathology, v. 21, p. 309-311, 1973.

WILDING, N. Emtomophthora species infecting pea aphis. Transactions Royal Entomological Society, v. 127, n. 2, p. 171-183, 1975.

WILDING, N. The effect of introducing aphid-pathogenia Entomophthoraceae into fiel populations of Aphis fabae. Annals of Applied Biology, v. 99, p. 11-23, 1981. 
WILDING, N. Entomophthorales: field use and effectiveness. In: INTERNATIONAL COLLOQUIUM ON INVERTEBRATE PATHOLOGY， 3， Brighton, 1982. Proceedings. Brighton: University of Sussex, 1982. p. 170-175.

WILDING, N.; MARDELL, S.K.; BROBYN, P.J. Introducing Erynia neoaphidis into a field population of Aphis fabae: form of the inoculum and effect of irrigation. Annals of Applied Biology, v. 108, p. 373-385, 1986.

WOLF, F.T. The cultivation of two species of Entomophthora on synthetic media. Bulletin of the Torrey Botanical Club, v. 78, n. 3, p. 211-220, 1951.

WRAIGHT, S.P.; BUTT, T.M.; GALAINI-WRAIGHT, S.G. ALEE, L.L.; SOPER, R.S.; ROBERTS, D.W. Germination and infection processes of the Entomophthoralean fungus Erynia radicans on the potato leafhopper, Empoasca fabae. Journal of Invertebrate Pathology, v.56, p.157-174, 1990.

WRAIGHT, S.P.; ROBERTS, D.W. Insect control efforts with fungi. Developments in Industrial Microbiology, v. 28, p.77-87, 1987.

YU, Z.; NORDIN, G.L.; BROWN, G.C.; JACKSON, D.M. Studies on Pandora neoaphidis (Entomophthorales: Entomophthoraceae) infectious to the red morph of tobacco aphid (Homoptera: Aphididae). Environmental Entomology, v. 24, p. 962-966, 1995. 
APÊNDICE 


\section{Meio Grace's suplementado}

\section{Sais}

$\mathrm{CaCh}_{2} \cdot 2 \mathrm{H}_{2} \mathrm{O}(0,06 \%)$

$\mathrm{MgCl}_{2} \cdot 6 \mathrm{H}_{2} \mathrm{O}(0,16 \%)$

$\mathrm{NaHCO}_{3}(0,03 \%)$

$\mathrm{KCl}(0,28 \%)$

$\mathrm{MgSO}_{4} .7 \mathrm{H}_{2} \mathrm{O}(0,2 \%)$

$\mathrm{NaH}_{2} \mathrm{PO}_{4} \cdot \mathrm{H}_{2} \mathrm{O}(0,1 \%)$

Vitaminas

$\begin{array}{lll}\text { Acido para-aminobenzoico }(0,002 \%) & \text { Tiamina } \mathrm{HCl}(0,002 \%) & \text { Biotina }(0,002 \%) \\ \text { D-Pantotenato de calcio }(0,002 \%) & \text { Riboflavina }(0,002 \%) & \text { Choline }(0,02 \%) \\ \text { Acido nicotinico }(0,002 \%) & \text { Acido folico }(0,002 \%) & \\ \text { Piridoxina } \mathrm{HCl}(0,002 \%) & \text { I-inositol }(0,002 \%) & \end{array}$

\section{Aminoacidos}

$\begin{array}{lll}\text { L-alanina }(0,0225 \%) & \text { L-glutamina }(0,06 \%) & \text { L-fenilalanina }(0,015 \%) \\ \beta \text {-alanina }(0,02 \%) & \text { Glicina }(0,065 \%) & \text { L-prolina }(0,035 \%) \\ \text { L-arginina. } \mathrm{HCl}(0,07 \%) & \text { L-histidina }(0,25 \%) & \text { L-serina }(0,055 \%) \\ \text { L-asparagina }(0,035 \%) & \text { L-isoleucina }(0,005 \%) & \text { L-treonina }(0,0175 \%) \\ \text { L-acido aspartico }(0,035 \%) & \text { L-leucina }(0,0075 \%) & \text { L-triptofan }(0,01 \%) \\ \text { L-cistina.2HCl }(0,00287 \%) & \text { L-lisina. } \mathrm{HCl}(0,0625 \%) & \text { L-tirosina.2Na }(0,0062 \%) \\ \text { L-acido glutâmico }(0,06 \%) & \text { L-metionina }(0,005 \%) & \text { L-valina }(0,01 \%)\end{array}$

\section{Outros componentes}

Frutose $(0,04 \%) \quad$ Acido fumárico $(0,0055 \%) \quad \alpha$-acido ketoglutarico $(0,037 \%)$

Sucrose $(2,668 \%) \quad$ Acido malico $(0,067 \%) \quad$ Lactalbumina hidrolisada $(0,33 \%)$

D-glucose $(0,07 \%) \quad$ Acido succinico $(0,006 \%) \quad$ Yeastolate $(0,33 \%)$ 